
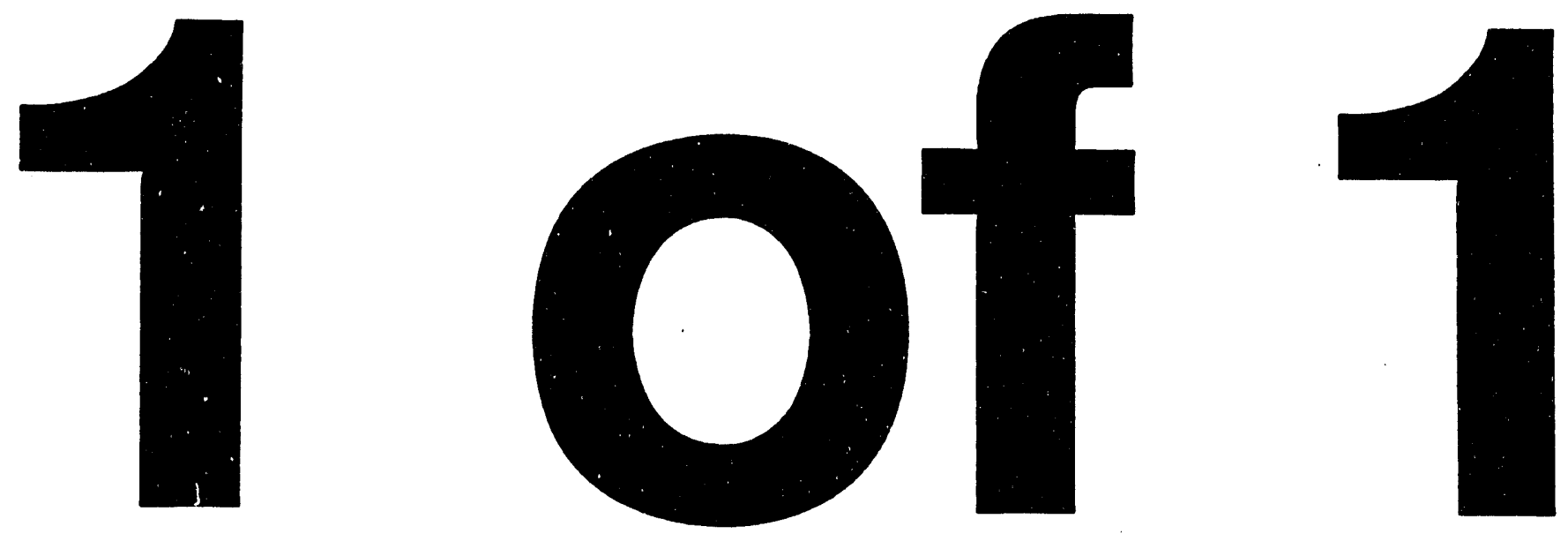


\section{Advanced Coal-Fueled Industrial Cogeneration Gas Turbine System -- Combustion Development}

\section{Topical Report}

R. T. LeCren

June 1994

Work Performed Under Contract No.: DE-AC2 1-86MC23166

For

U.S. Department of Energy

Office of Fossil Energy

Morgantown Energy Technology Center

Morgantown, West Virginia

By

Solar Turbines, Inc.

San Diego, California 


\section{DISCLAIMER}

This report was prepared as an account of work sponsored by an agency of the United States Government. Neither the United States Government nor any agency thereof, nor any of their employees, makes any warranty, express or implied, or assumes any legal liability or responsibility for the accuracy, completeness, or usefulness of any information, apparatus, product, or process disclosed, or represents that its use would not infringe privately owned rights. Reference herein to any specific commercial product, process, or service by trade name, trademark, manufacturer, or otherwise does not necessarily constitute or imply its endorsement, recommendation, or favoring by the United States Government or any agency thereof. The views and opinions of authors expressed herein do not necessarily state or reflect those of the United States Government or any agency thereof.

This report has been reproduced directly from the best available copy.

Available to DOE and DOE contractors from the Office of Scientific and Technical Information, 175 Oak Ridge Tumpike, Oak Ridge, TN 37831; prices available at (615) 576-8401.

Available to the public from the National Technical Information Service, U.S. Department of Commerce, 5285 Port Royal Road, Springfield, VA 22161; phone orders accepted at (703) 487-4650. 


\title{
Advanced Coal-Fueled Industrial Cogeneration Gas Turbine System -- Combustion Development
}

\author{
Topical Report
}

\author{
R. T. LeCren
}

Work Performed Under Contract No.: DE-AC2 1-86MC23166

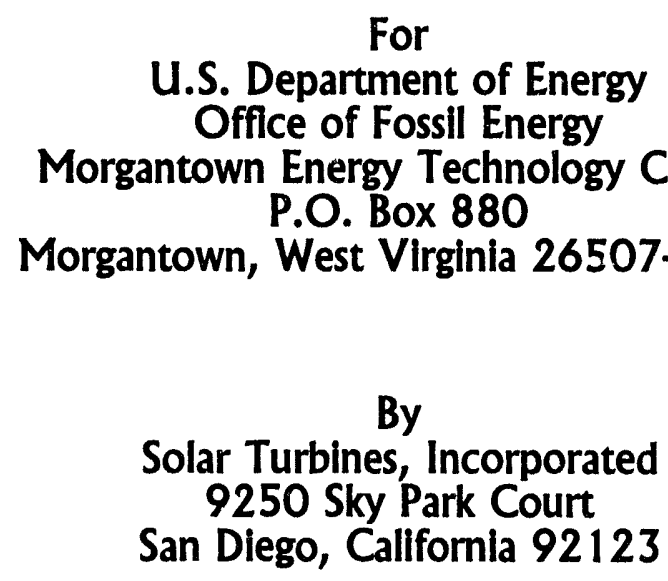

June 1994 
CONTENTS

Section

Page

ABBREVIATIONS AND SYMBOLS

1.0

INTRODUCTION

2.0

ACHIEVEMENTS

3.0

DISCUSSION

3.1 Combustor Performance Davelopment

3.2 Slag Removal

3.3 Crude Oil Evaluation

6

3.4 Sulfur Oxide Removal

3.5 Fuel Property specification Testing

3.6 Injector Development

4.0

CONCLUSIONS

63

5.0

RECOMMENDATIONS

64

REFERENSES

65

APPENDIX A

66 


\section{FIGURES}

Eloure

Water-Flushed Slag Pit

Baseline TSSC With Water-Quenched Slag Pit

Slag Removal System

TSSC Test Configuration for Evaluation of Fuels of Varying Properties

Primary Injector Section After the TSSC Crude Oil Test

A) Hole Near Weld on Primary Zone Injector, B) Injector Face

Effects of Varied Air Assist Pressure on NOX

Combustor Performance Shown by Primary Zone Equivalence Ratio vs. Measured Oxygen in the Effluent

Actual Measured $\mathrm{SO}_{2}$ Levels at Varying Dolomite Injection Rates Compared to Theoretical $\mathrm{SO}_{2}$ Levels Based on Fuel Sulfur Content With No Sorbent Injection 


\section{FIGURES (Continued)}

Eloure

$\mathrm{SO}_{2}$ Emission Reductions for Dolomite Injection in the

Comparison of $\mathrm{SO}_{2}$ With Varying Injection Rates of Three Sorbents Into the Secondary Zone of the TSSC

$\mathrm{SO}_{2}$ Reduction of Dolomite Injected in the Secondary Zone of the TSSC Buming CWMs of Varying Sulfur Loading

$\mathrm{SO}_{2}$ Emissions at Varying Ca/S Ratios of Dolomite Injection

Comparison of SO2 Reductions of Dolomite of Varying Sizes Injected into the Secondary zone

TSSC Test Configuration for Evaluation of Fuels of Varying Properties

Outlet Temperature Profile of TSSC Buming CWMs of Varying Coal Loadings

NOx Emissions of TSSC Buming CWMs of Varying Coal Loadings

Variation of Outlet Temperature With Fuels of Varying Coal

Ash Concentration

Variation of NOx Emissions With Fuels of Varying Coal Ash

Outlet Temperature and Emission Characteristics of TSSC Buming CWMs Made From Coals of Varying Particle Size 


\section{TABLES}

Iable

Page

1

2

3

4

5

6

7

8

9

10

11

12

13

14

15

Summary of TSSC Combustor Testing

8

Slag Tap Heating in Atmospheric Tests Firing Slag Tap Torches Only

Summary of CWM Testing of Fuels of Varying Properties

Summary of TSSC Combustor Testing of Slag Removal System

Emissions Data From TSSC Crude Oil Test 2

Particulate analysis of Sample Collected in Test No. 500 With

Dolomite Injection

Chemical and Physical Analyses of Calcium-Based Sorbents

Used in Recent Tests

Analyses of Calcium-Based Sorbents

Result of Combustor Performance With Three Sorbents Injected into Secondary Zone

Properties of Dolomite of Different Grinds

Properties and Compositions of Combustion Testing Fuels

Summary of CWM Testing of Fuels of Varying Properties

Particulate Sample Analyses From Test Completed in TSSC With CWMs of Varying Fuel Properties 


\section{ABBREVIATIONS AND SYMBOLS}

$\begin{array}{ll}\text { AMAX } & \text { Amax Research \& Development Center } \\ \text { CFC } & \text { Coal fueled Centaur } \\ \text { CSC } & \text { Component Screening Combustor } \\ \text { CWM } & \text { Coal-Water Mixture } \\ \text { DCFGT } & \text { Direct Coal Fired Gas Turbine } \\ \text { HESR } & \text { Hot End Simulation Rig } \\ \text { IBSTF } & \text { Integrated Bench Scale Test Facility } \\ \text { PRIS } & \text { Particulate Removal Impact Separator } \\ \text { SEM } & \text { Scanning Electron Microscopy } \\ \text { TSSC } & \text { Two Stage Slagging Combustor } \\ \text { CP } & \text { centipoise } \\ \text { seC } & \\ \text { F/S } & \text { full size } \\ \text { LHV } & \text { over heating value } \\ \text { MMBtu } & \text { million British Thermal Units (based on Lower Heating Value) } \\ \text { MMBtu/hr } & \text { million British Thermal Units per hour (based on Lower Heating Value) } \\ \text { MW } & \text { mega watt } \\ \text { PHI } & \text { equivalence ratio } \\ \text { P } & \text { inlet air pressure } \\ \text { pph } & \text { pounds per hour } \\ \text { ppm } & \text { parts per million } \\ \text { Ppmm } & \text { parts per million by mass } \\ \text { ppmv } & \text { parts per million by volume } \\ \text { psig } & \text { pounds per square inch gauge } \\ T_{\text {m }} & \text { inlet air temperature } \\ T_{\text {oute }} & \text { secondary combustor outlet temperature } \\ T_{\text {PAis }} & \text { micron } \\ \text { um } & \end{array}$

Note: Gaseous emissions $\left(\mathrm{NO}_{\mathrm{x}}, \mathrm{CO}, \mathrm{UHC}, \& \mathrm{SO}_{2}\right.$ ) are quoted in parts per million by volume corrected to $15 \%$ oxygen in the exhaust on a dry basis unless otherwise specified. 


\subsection{INTRODUCTION}

This topical report summarizes the combustor development work accomplished under the subject contract. The objective was to develop a combustion system for the Solar 4MW Type H Centaur gas turbine generator set which was to be used to demonstrate the economic, technical and environmental feasibility of a direct coal-fueled gas turbine in a 100 hour proof-of-concept test. The development was carried out using two different scale combustors and three different test rigs. The initial design was carried over from previous contracts (DE-AC21-83MC20229, Low Emission Combustor and DE-AC21-84MC21284, Component Screening Fuel Flexible Combustor). The test combustor during the previous contract was a 1/10th scale of that required for the Type H Centaur gas turbine generator set. The initial objective was to solve operational problems encountered with this combustor and then scale the design up to full size. Before the contract was curtailed a full size system (primary zone, particulate removal system and secondary zone) was designed, fabricated, installed in a test facility at Caterpillar Tech Center and preliminary testing accomplished. At this point some problems existed but solutions were in hand and preparations for a 100 hour proof-ofconcept engine test had begun.

This program started with a design configuration derived during the CSC program. The design went through the following evolution: CSC design which had some known shortcomings, redesigned CSC now designated as the Two Stage Slagging Combustor (TSSC), improved TSSC with the PRIS evaluated in the IBSTiF, and full scale design. Supporting and complimentary activities included computer modelling, flow visualization, slag removal, $\mathrm{SO}_{x}$ removal, fuel injector development and fuel properties evaluation. Three combustor rigs were utilized: the TSSC, the IBSTF and the full scale rig at Peoria. The TSSC rig, which was 1/10th scale of the proposed system, consisted of a primary and secondary zone and was used to develop the primary zone performance and to evaluate $\mathrm{SO}_{\mathrm{x}}$ and slag removal and fuel properties variations. The IBSTF rig which included all the components of the proposed system was also 1/10th scale except for the particulate removal system which was about $1 / 30$ th scale. This rig was used to verify combustor performance data obtained on the TSSC and to develop the PRIS and the particulate removal system. The full scale rig initially included the primary and secondary zones and was later modifled to incorporate the PRIS. The purpose of the full scale testing was to verify the scale up calculations and to provide a combustion system for the proof-of-concept engine test that was initially planned in the program. 


\subsection{ACHIEVEMENTS}

- Stable and efficient combustion buming coal-water mixtures using the Two Stage Slagging Combustor.

- Molten slag removal of over $97 \%$ using the slagging primary zone and the particulate removal impact separator

- The feasibility of on-site CWM preparation was demonstrated on the subscale TSSC.

- A continuous slag removal system was tested on the scale combustor providing design information for the full size configuration.

- Completed an evaluation of coal-water mixture properties on combustor performance

- A water-cooled impactor was evaluated on the subscale TSSC.

- Four tests were completed on the full size TSSC, tha last one incorporating the PRIS.

- A prototype design of an effervescent fuel injector was completed by Solar using design guidelines developed by Purdue. A set was ordered and tested.

- A target fuel specification was established and a fuel cost model developed which can identify sensitivities of specification parameters. 


\subsection{DISCussion}

\subsection{COMBUSTOR PERFORMANCE DEVELOPMENT}

The combustor tested in the Component Screening Combustor Program had two major shortcomings as shown in Figure 1. Slag would flow up the top cone through the transition and into the secondary. It was theorized that this slag would be captured by the PRIS when it was incorporated but would increase the amount of slag to be captured. The second problem was the escape of unbumea fuel by way of a secondary recirculation zone as shown. This fuel would only partially bum in the secondary zone and therefore would result in reduced combustion efficiency.

To solve these two problem areas computer modelling and flow visualization were employed. A computer program called INTERN was utilized to analyze the problem and to suggest solutions. The CSCTSSC design was not conventional in that the inlet and exhaust were at the same end which was different from the configuration that INTERN was developed for. However the input was modified to allow meaningful results to be obtained. Figure 2 is a sample output. Plexiglass models were constructed for flow visualization. Neutral density helium-filled soap bubbles were utilized as tracers. Both still and high speed photography were used to document the observations. Video recordings were also made.

Three configurations which were studied are shown in Figure 3. The approaches were essentially the same in each and that was to move the accelerating exit from the primary zone away from the point of injection. In configuration No. 1 the approach was to raise the top wall or cone so that the slag would not accelerate into the transition and fuel in the secondary recirculation would react before reaching the exhaust. Configuration No. 3 was similar to No. 1 except for the angled walls

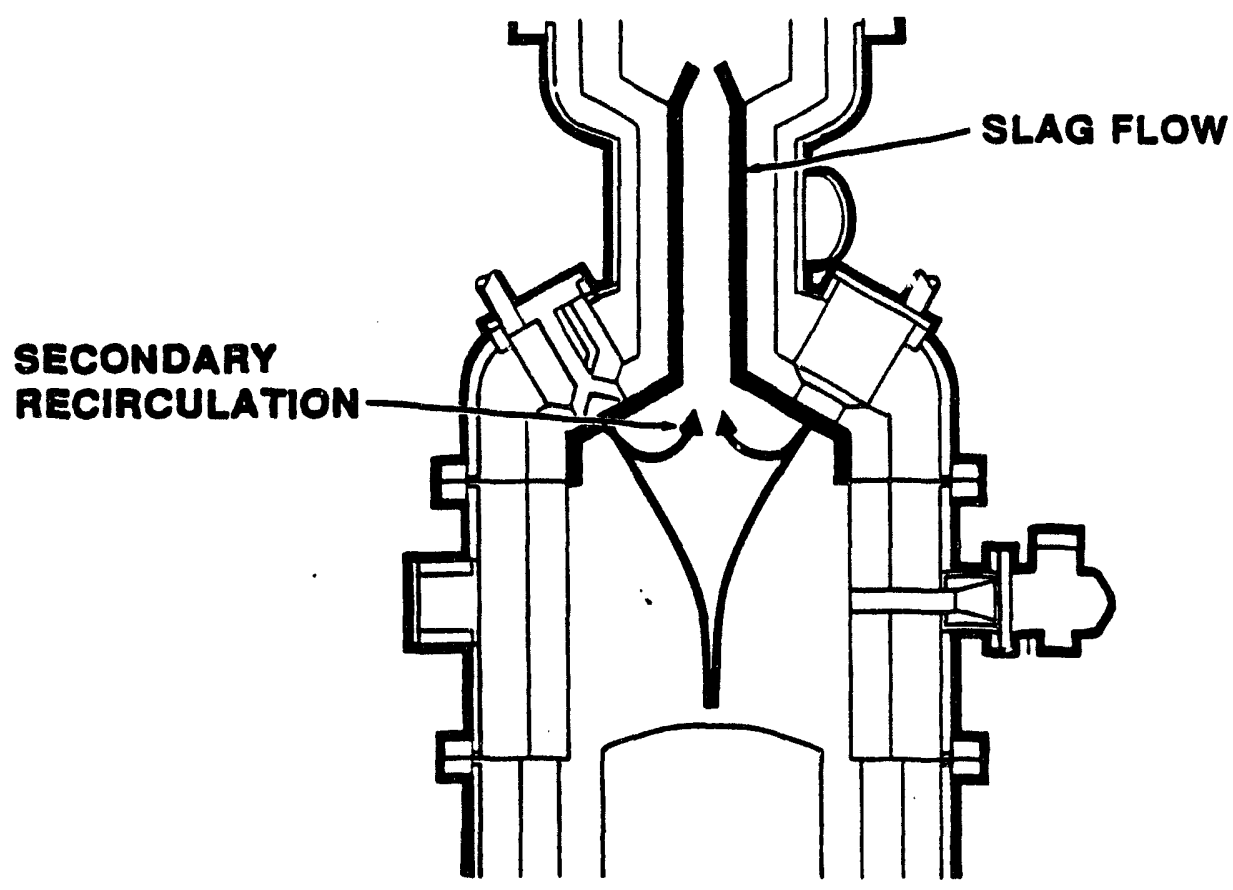

Figure 1. Baseline Combustor Deficiencles 
suopeolıpow u6jseg enoz Ruwhd' 'E edn6IJ

$\varepsilon \cdot O N$

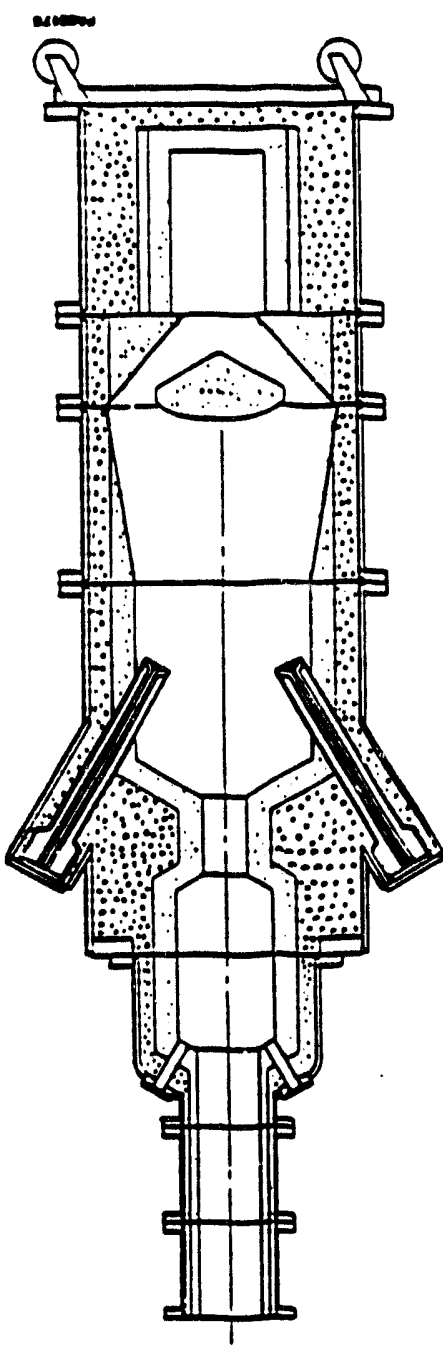

$Z^{\cdot O N}$

q

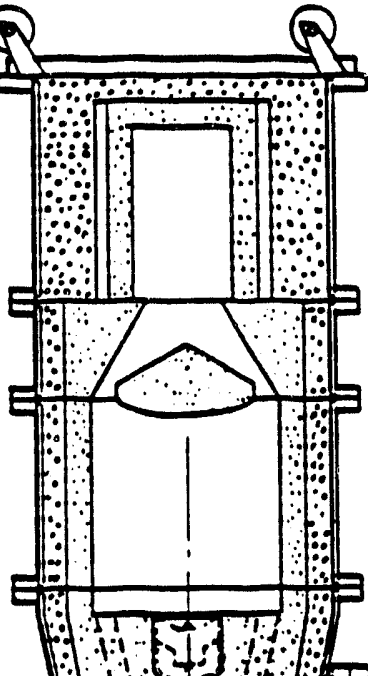

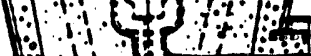

$41 \frac{1}{110}=$

i11

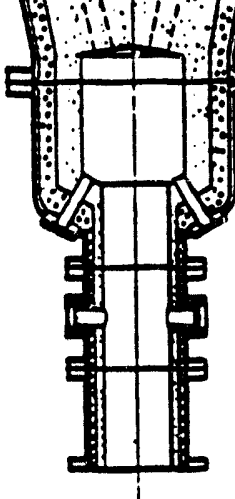

$I^{\cdot} \cdot \mathrm{ON}$

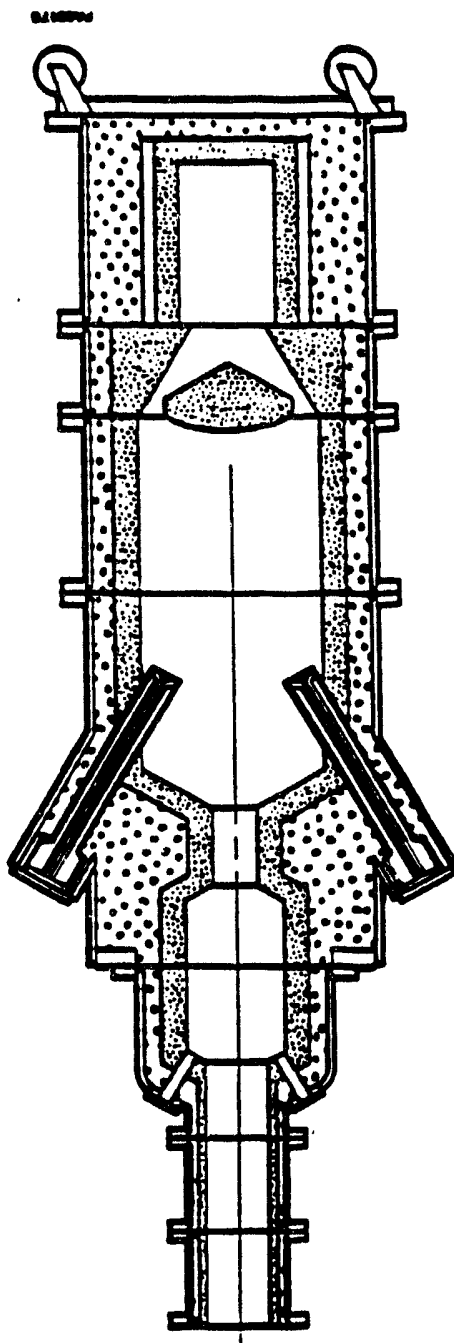

XL - jopow dojenquos poos r ean6ly

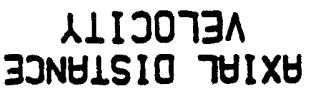

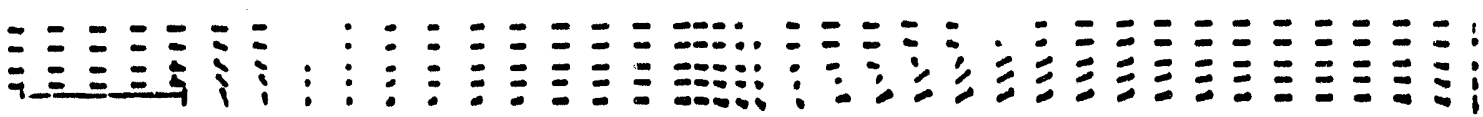

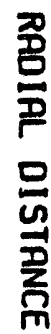


below the plane of the injectors. This change we found to intensify the main recirculation patterns which improved slag capture. The approach in Configuration No. 2 was to utilize a single injector and move the exit from the primary to the outer edge. The use of a single injector eliminated the need to align multiple injectors to obtain a single downward flowing jet. Relocation of the exits removed the need for the exiting gases to flow over or near the incoming flow thus minimizing the possibility of unburnt fuel escaping. Of the three Configuration No. 3 was the most promising.

Tests were run to compare the three configurations. All were an improvement over the baseline with No. 3 better than No. 1 and No. 2 comparable to No. 3. During this series of tests the full size combustor was being designed. Both single and four injector configurations were considered. The design fuel flow for the TSSC was $600 \mathrm{pph}$. Since the full size combustor was 10 times larger the design fuel flow was $6000 \mathrm{pph}$. The fuel flow per injector for the 4 injector TSSC was $150 \mathrm{pph}$, for the single injector TSSC - 600 pph, for the 4 injector full size combustor - 1500 pph and for a single injector full size combustor - $6000 \mathrm{pph}$. During the injector development it was determined that satisfactory performance with a 6000 pph injector was difficult to attain, while it was with a 1500 pph injector. Since the purpose of the TSSC testing was to support the full size design all testing with a single injector TSSC was halted. Almost all of the testing described in Sections 3.2 through 3.5 was done with a four injector TSSC having conical walls as shown in Figure 3.

\subsection{SLAG REMOVAL}

Since $60-70 \%$ of "ie mineral matter in the coal would be removed in the primary zone of the TSSC a viable continuous slag removal system was needed. Design and testing of candidate removal systems was carried on in the subscale TSSC. The development path for continuous slag removal was to 1) assess the impact on combustor performance of a water bath located below the slag tap, 2) determine the properties of the slag collected in the water bath, and 3) design and test a continuous slag removal system.

At the outset of this work the design of the slag system was narrowed to two altematives. Both designs had a water bath for quenching the slag and a lock hopper arrangement for slag removal. The designs differed in that one had a slag auger/crusher and the other did not. The first two parts of the development path listed above were completed to make a decision between these two design alternatives. Testing was completed in a series of four tests (Nos. 38, 39, 45 and 46). The first two tests were aimed at determining the impact of a water bath on combustor performance and the properties of the quenched slag. This testing indicated that the presence of a water bath has no impect on combustor performance and that the slag collected in the bath is generally in the form of crushable pellets. With this information it was determined that a slag/auger crusher would not be necessary. Testing was conducted on a simple lock hopper arrangement. Key results indicated that rapid purging of the water and slag through a valve is possible and that this process has no detectable impact on the combustor operation. The one remaining area pursued was efficient slag tap heating.

Testing started with a water quenched slag pit attached to the baseline TSSC. The combustor with the water quenched slag pit is pictured in Figure 4. The slag pit had a refractory lined upper half and exposed steel case on the bottom. The slag tap hole was 4 inches in diameter. Three of Solar's Satum engine torches were used to heat the slag tap hole to prevent freezing and blockage. The torches bum natural gas and air from sources independent of the combustion air. Water was introduced through the upper pipe and exited through the lower pipe. The water was circulated to prevent boiling. The water level was controlled manually by watching the 12 thermocouples located 
EXISTINO TSSC

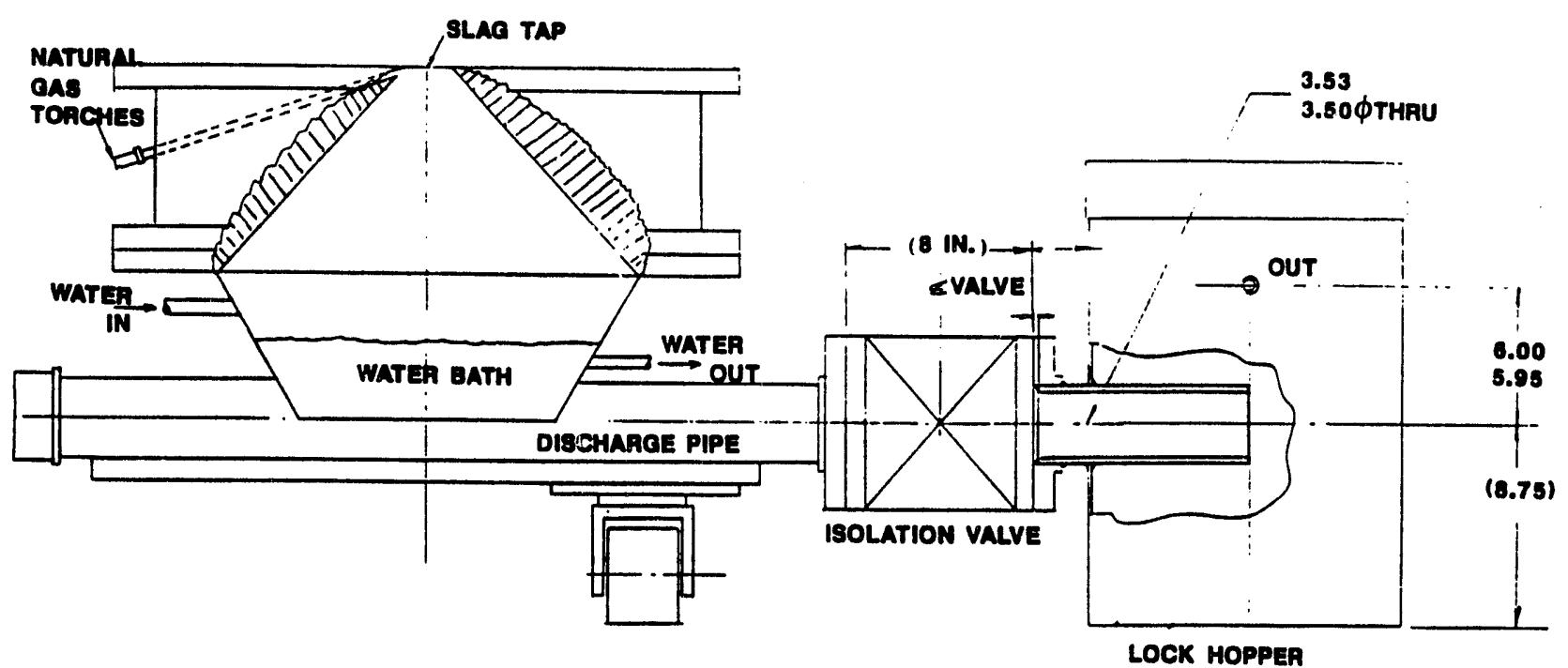

Figure 4. Water-Flushed Slag Plt

immediately above and below the water line. The water flow rate was 3 to 5 gpm through the slag pit. Water that exited through the outlet pipe passed through a filter to collect any particulate and slag that was entrained.

The system was operated on CWM in both TSSC Test Nos. 37 and 38. in Test No. 37 the combustor was operated at 40 psig for 3 hours on diesel fuel and then switched over to CWM buming a total of one barrel. Test 38 was operated at 80 psig over a longer time buming a total of four barrels of CWM. Test conditions and results are summarized in Table 1 . In both tests the combustor ran very well with no noticeable influence from the water in the slag pit. The three slag tap torches were run continuously to maintain a high slag tap temperature. The temperature of the water entering the slag pit was steady at $80^{\circ} \mathrm{F}$ and the water exiting never climbed above $110^{\circ} \mathrm{F}$ indicating the likelihood of excessive water vaporization was low. The emissions were typical of tests with the baseline TSSC.

Materials collected in the water bath from these tests were analyzed and divided into four categories. In the two tests the majority (80\%) of the material was in the form of slag pellets approximately 0.25 inch long. These pellets can be crushed by hand. The pellets are $99.8 \%$ ash and $0.2 \%$ carbon. Slag was also collected in the form of aggregates (15\%) with a mean size of 0.25 to 0.5 inches and ne dimensions larger than 1 inch. This material was also $99.8 \%$ ash and $0.2 \%$ carbon. The remaining slag pit contents were unburned carbon which was $90.5 \%$ carbon and $9.5 \%$ ash. The unbumed carbon was in the form of large "briquettes" and fine dust. It should be noted that in Test No.38 all the material was in the form of slag pellets.

This data indicated that all the material collected in the slag pit was small enough to be successfully handled by a valve and lock hopper arrangement. A subscale unit was designed and fabricated for lest. In this design a three inch ball valve was used to fill a lock hopper with periodic flushes of the slag pit contents. The system, illustrated in Figure 5, featured a torch heated slag tap hole, a water bath, a discharge pipe, an isolation ball valve, and a lock hopper. During combustor operation the slag removed from the primary zone flowed through the slag tap hole and dripped into the water 
Table 1. Summary of TSSC Combustor Testing

\begin{tabular}{|c|c|c|c|c|c|c|c|}
\hline Tent Facellity & TSec & TSsc & Tssc & Tsec & TSSC & TSSc & TSsc \\
\hline Teen No. & 34 & 38 & 30 & 37 & 38 & 30 & 40 \\
\hline Oojective & $\begin{array}{l}\text { Sortent } \\
\text { Evaluation }\end{array}$ & $\begin{array}{l}\text { Sorteent } \\
\text { Evacuation }\end{array}$ & $\begin{array}{l}\text { Sortemt } \\
\text { Evituetion }\end{array}$ & $\begin{array}{l}\text { Sibg } \\
\text { Removal }\end{array}$ & $\begin{array}{l}\text { Sing } \\
\text { Pemoval }\end{array}$ & $\begin{array}{l}\text { Singelo } \\
\text { Removal }\end{array}$ & $\begin{array}{l}\text { Singlo } \\
\text { Injector }\end{array}$ \\
\hline cunns & $\mathbf{F}$ & $\mathbf{F}$ & ${ }^{\circ}$ & $\mathbf{W}$ & $\mathbf{N}$ & $\mathbf{N}$ & $\mathbf{N}$ \\
\hline$T_{n}\left({ }^{\circ} \cap\right)$ & $\infty 20$ & 650 & 691 & 604 & 627 & 616 & 607 \\
\hline$P_{n}$ (pato) & 75 & 74.6 & 74.3 & 73.3 & 74.0 & 74 & 74 \\
\hline$T$ (P) & 1800 & 1840 & 1607 & 1000 & 1801 & 1800 & 1600 \\
\hline ronسب & 1.30 & 120 & 1.00 & 1.20 & 0.01 & 1.28 & 1.20 \\
\hline $\begin{array}{l}\text { MO, (opm) } \\
\text { (bommmewu) }\end{array}$ & $\begin{array}{l}87.5 \\
(0.3747)\end{array}$ & $\begin{array}{l}80.5 \\
(0.3707)\end{array}$ & $\begin{array}{l}114.1 \\
\text { (0.6070) }\end{array}$ & $\begin{array}{l}124.0 \\
(0.6000)\end{array}$ & $\begin{array}{l}121.0 \\
(0.4014)\end{array}$ & $\begin{array}{l}180 \\
(0.000 x)\end{array}$ & $\begin{array}{l}147 \\
(0.5001)\end{array}$ \\
\hline $\begin{array}{l}c o \text { (ppm) } \\
\text { (tominuevu) }\end{array}$ & $\begin{array}{l}12.9 \\
(0.0860)\end{array}$ & $\begin{array}{l}9.0 \\
(0.0250)\end{array}$ & $\begin{array}{l}10.1 \\
(0.265)\end{array}$ & $\begin{array}{l}41.0 \\
(0.1014)\end{array}$ & $\begin{array}{l}10.6 \\
(0.04806)\end{array}$ & $\begin{array}{l}160 \\
(0.3711)\end{array}$ & $\begin{array}{l}\infty 0 \\
(0.22)\end{array}$ \\
\hline $\begin{array}{l}\mathrm{SO}_{2} \text { (oppm) } \\
\text { (lomingw) }\end{array}$ & $\begin{array}{l}540.1 \\
(32002)\end{array}$ & $\begin{array}{l}663.1 \\
\text { (3.0502) }\end{array}$ & $\begin{array}{l}848.7 \\
(4.0210)\end{array}$ & - & $\begin{array}{l}73.6 \\
(0.4460)\end{array}$ & $\begin{array}{l}187 \\
(1.0710)\end{array}$ & $\begin{array}{l}165 \\
(0.023)\end{array}$ \\
\hline APP Pitnary (X) & 4.1 & 3.9 & 4.2 & 4.1 & 3.0 & 4.1 & 4.2 \\
\hline Carton Converion & $\infty 0.0$ & 20.6 & - & $\boldsymbol{\infty} 2$ & - & $\mathbf{8 5 . 0}$ & - \\
\hline 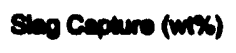 & 84 & 84 & 46 & - & 320 & - & - \\
\hline 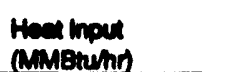 & 4.17 & 4.10 & 4.12 & 220 & 397 & 400 & 4.10 \\
\hline
\end{tabular}

bath, freezing instantaneously. The water bath had both inlet and outlet pipes for continuous water circulation to prevent boiling. Slag collected in the water bath sank to the bottom of the discharge pipe. After a given time period the isolation valve was rapidly opened and closed to fill the lock hopper with water and slag. The lock hopper could be chargec with air pressure to control the pressure drop taken across the isolation valve.

The test hardware was designed to fit the existing TSSC rig which required that a very tight height requirement be placed on the slag removal system. The discharge pipe axis was at a right angle to the combustor centertine. One end of the discharge pipe was capped and the other was connected to the lock hopper with an isolation valve in between. In the full scale combustor a lock. hopper can be positioned directly beneath the water bath and isolation valve without the need for a discharge pipe. Therefore, the full scale design should be more effective in removing all the slag collected in the water bath than this subscale haroware. If the subscale hardware could be proven to effectively remove slag than the scaled design would be even more effective.

The isolation valve and lock hopper arrangement was run in two tests. TSSC Test Nos. 45 and 46 were run at typical test conditions buming CWM $\mathrm{T}$. The combustor ran well with key operating parameters listed in Table 1. The tests were run for slightly less than two hours on CWM. The slag tap torches were operated throughout the tests while buming CWM. The isolation valve on the lock hopper was opened and the slag pit was purged eleven times in both tests. The purge operation was completed without any noticeable impact on the system while looking at such operating parameters as primary zone pressure, outlet temperature, and emission traces. Slag tap 
Table 1. Summary of TSSC Combustor Testing (Continued)

\begin{tabular}{|c|c|c|c|c|c|c|}
\hline Teat Faciny & TSSC & Tssc & TSSC & TSsC & TSSC & TSSC \\
\hline Ten No. & 41 & 42 & 43 & 4 & 46 & 40 \\
\hline Objective & Sinots injector & Single injectorisorbent & $\begin{array}{l}\text { CWM } \\
\text { Properties }\end{array}$ & $\begin{array}{l}\text { CWM } \\
\text { Propertices }\end{array}$ & $\begin{array}{l}\text { Sha } \\
\text { Removal }\end{array}$ & $\begin{array}{l}\text { Shap } \\
\text { Removel }\end{array}$ \\
\hline CWMP & $w \& L^{\prime}$ & $p$ & 's1' & ser & $\mathbf{T}$ & $\mathbf{T}$ \\
\hline$T_{n}(\cdot F)$ & $\infty$ & 615 & 603 & 608 & 630 & 658 \\
\hline$P_{n}(p+p)$ & 74 & 76 & 75 & 75 & 70 & 75 \\
\hline$T_{\operatorname{mon}}\left({ }^{\circ} \mathrm{F}\right)$ & 1680 & 1860 & 1810 & 1783 & 1003 & 1900 \\
\hline ram & 1.20 & 1.12 & 1.27 & 1.25 & 1.30 & 1.37 \\
\hline $\begin{array}{l}\text { NO, (ppm) } \\
\text { (bommuBw) }\end{array}$ & $\begin{array}{l}147 \\
(0.6001)\end{array}$ & $\begin{array}{l}182 \\
(0.8200)\end{array}$ & $\begin{array}{l}48.0 \\
(0.2082)\end{array}$ & $\begin{array}{l}24.4 \\
(0.2680)\end{array}$ & $40.0(0.1970)$ & $\begin{array}{l}48.8 \\
(0.1950)\end{array}$ \\
\hline $\begin{array}{l}\text { CO (ppm) } \\
\text { (bmMMBEu) }\end{array}$ & $\begin{array}{l}80.0 \\
(0.220)\end{array}$ & $\begin{array}{l}15.8 \\
(0.0395)\end{array}$ & $\begin{array}{l}4.3 \\
(0.011)\end{array}$ & $\begin{array}{l}6.8 \\
(0.0160)\end{array}$ & $\begin{array}{l}2.8 \\
(0.0088)\end{array}$ & $\begin{array}{l}2.2 \\
(0.0050)\end{array}$ \\
\hline $\begin{array}{l}\text { SO, (ppm) } \\
\text { (bommuBw) }\end{array}$ & $\begin{array}{l}165.0 \\
(0.8230)\end{array}$ & $\begin{array}{l}388 \\
(2.05)\end{array}$ & $\begin{array}{l}164 \\
(0.958)\end{array}$ & $\begin{array}{l}170 \\
(0.989)\end{array}$ & - & - \\
\hline APp Primary (x) & 4.0 & 4.1 & 4.0 & 4.0 & 4.1 & 4.0 \\
\hline Carbon Comverion & - & 24 & - & - & - & - \\
\hline Sing Capure (wits) & $\infty$ & 37 & 68.0 & SA.0 & 70 & - \\
\hline Heet inoun (MMBrump) & 4.29 & 4.32 & 4.14 & 4.32 & 4.70 & 5.08 \\
\hline
\end{tabular}

temperatures measured in the refractory at a depth of about one-half inch reached a maximum average value of 1811 and $1883^{\circ} \mathrm{F}$ in Test Nos. 45 and 46, respectively. A thermocouple mounted flush with the inner refractory surface located slightly below the impactor reached a maximum of 1683 and $2040^{\circ} \mathrm{F}$, respectively.

Post test inspection revealed that only a small amount (less than one pound for each test) of slag reached the water bath. The water flush carried approximately half of this slag into the lock hopper. Most of the slag froze only several inches below the impactor well above the slag tap hole. The slag tap hole was virtually clean. The results indicate that the slag tap was too cool for both tests. In TSSC Test No. 46 an effort was made to reduce the heat transfer from the slag tap area. This design modification was slightly successful as indicated by the temperatures cited above, but still the slag tap was too cool. These tests indicated that more work was required in efficiently heating the slag tap.

In order to decrease heat loss from the slag tap a series of insulation geometry tests were completed at atmospheric pressure running the torches only. The slag tap geometries tested are shown schematically in Figure $6 a$ to $6 \theta$. This hardware was operated firing the slag tap torches and allowing the exhaust to vent directly into the test cell. The hardware consisted of the impactor spool, the slag tap heating spool, a spacer spool, and the water bath/discharge pipe section. Design Nos. 1 and 2, illustrated in Figures $6 b$ and $c$, were operated in the CWM combustion tests TSSC Nos. 45 and 46, respectively. Listed in Table 2 are the results of the atmospheric tests with these four slag tap heating geometries. All four designs were tested at the same conditions with gas inlet pressures of $30 \mathrm{psig}$ and air inlet pressures of $4.5 \mathrm{psig}$. The results clearly indicate that the highest slag tap temperatures are achieved with design \#4. "Kaoboard" insulating rings below the slag tap in designs 


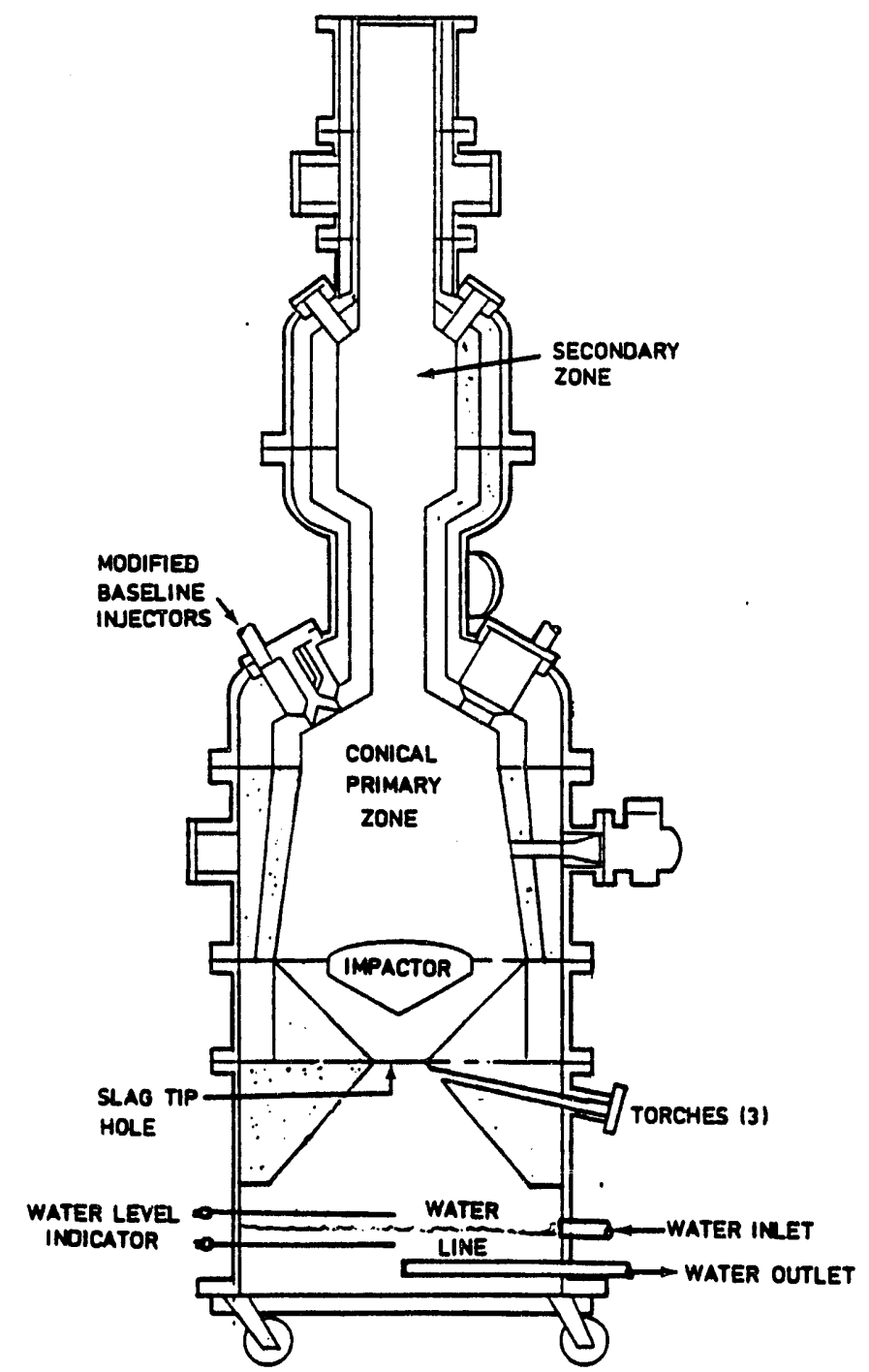

Figure 5. Baseline TSSC With Water-Quenched Slag Pit

3 and 4 were installed to retard radiant heat transfer from the slag tap to the water bath. These rings had the added benefit of providing an annular gap for torch flame stabilization. In design 4 an insulated spool was added to increase the distance from the slag tap to the water bath. This design more accurately reflects the distance that will be designed into the full scale combustor slag removal system. The design 4 was tested in TSSC Test No. 47 for performance characterization.

In summary, design and test work was completed in the TSSC of a continuous slag removal system. The system consisted of a slag tap, a water bath, and a lock hopper. Initial testing with a 'batch' type water quench slag pit indicated that slag collected in the bath was conveniently sized for handling with a simple lock hopper and additional crushing/augering of the slag would not be required. The presence of a water bath had no noticeable impact on the combustor's performance. Testing with a water bath and lock hopper was started. An isolation valve was opened for slag pit purging successfully in over ten cycles. The purging operation had no noticeable impact on the combustor's operation. Heating the slag tap effectively was important for successful slag removal and work continued in this area. 


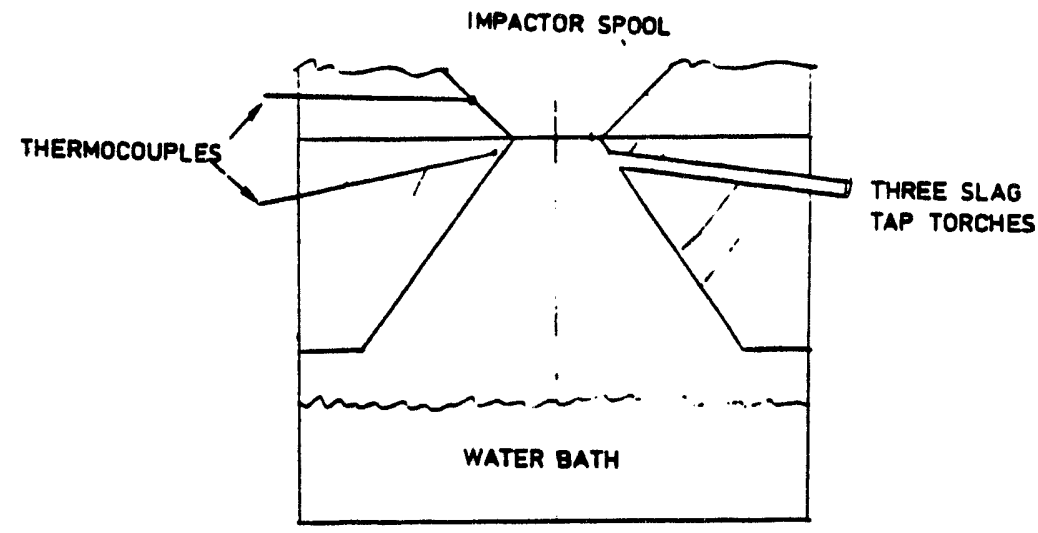

A. WATER BATH ANO BATCH SLAG PIT

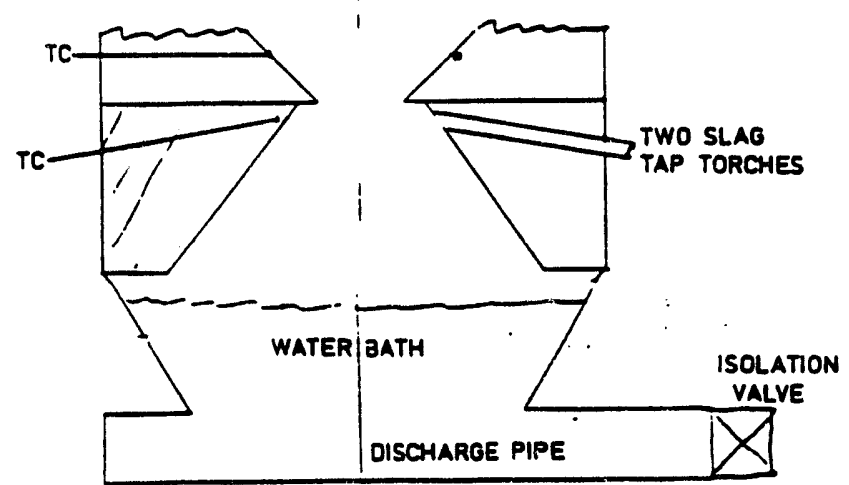

B. DESIGN "1. SUBSCALE WATER QUENCHEd SLAG REMOVAL SYSTEM

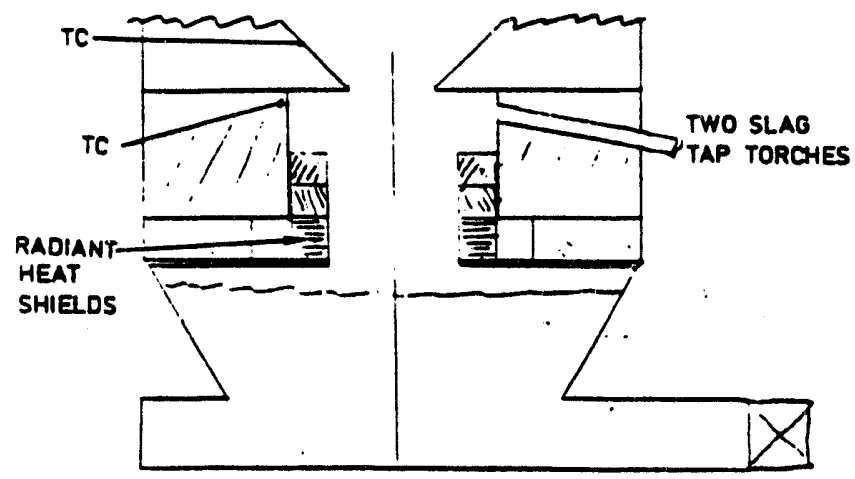

D. DESIGN *3. SLAG REMOVAL SYSTEM WITH RADIANT heAT SHEDOS

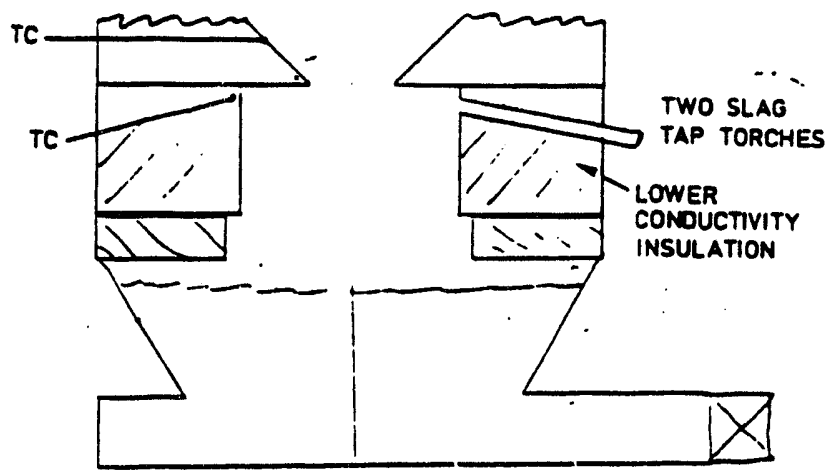

C. DESIGN *2. SLAG REMOVAL SYSTEM WITH LOWER HEAT LOSS REFRACTORY

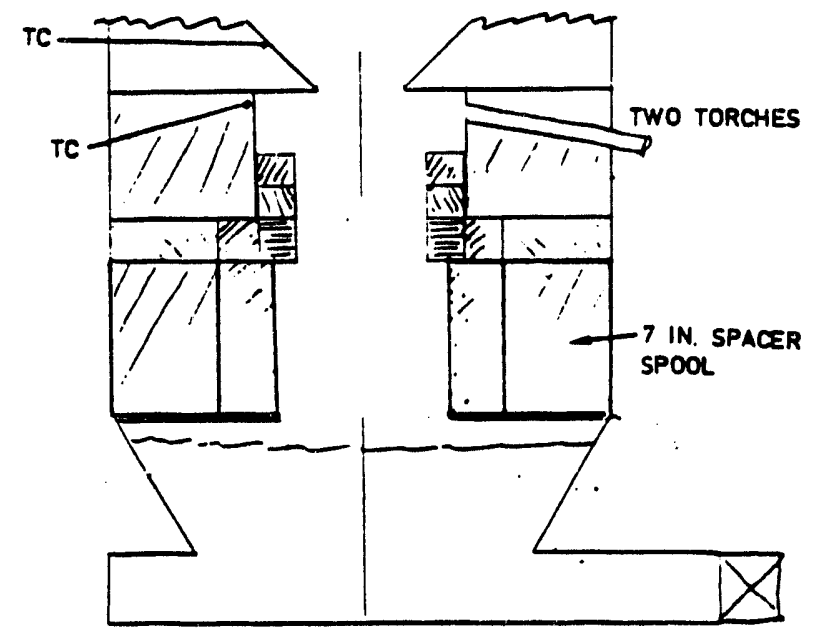

E. DESIGN A6. SLAG REMOVAL SYSTEM WITH LARGER SLAO TAP TO WATER BATH DISTAMCE

Figure 6. Slag Test Geometries Tested 
Table 2. Slag Tap Heating in Atmospheric Tests Firing Slag Tap Torches Only

\begin{tabular}{|c|c|c|c|}
\hline & \multicolumn{3}{|c|}{ Slag Removal Design Numbers } \\
\hline & \#2 & \#3 & $\# 4$ \\
\hline Natural Gas Input (psid) & 31.5 & 31.6 & 31.5 \\
\hline Torch Air Input (psid) & 4.65 & 4.65 & 4.65 \\
\hline \multicolumn{4}{|l|}{ Iemperature* } \\
\hline Slag Tap ( $\left.{ }^{\circ} \mathrm{F}\right)$ & 2050 & 2345 & \\
\hline $\begin{array}{l}\text { Refractory Surrounding } \\
\text { Tap }\left({ }^{\circ} \mathrm{F}\right)\end{array}$ & 1379 & 1265 & 1424 \\
\hline $\begin{array}{l}\text { In Gap Between Impactor and } \\
\left.\text { Wall ( }{ }^{\circ} \mathrm{F}\right)\end{array}$ & 1021 & 1168 & 1136 \\
\hline $\begin{array}{l}\text { "Temperatures measured with } \\
\text { with water in bath. }\end{array}$ & contin & peratio & \\
\hline
\end{tabular}

The continuous slag removal device development has continued in this reporting period. Preliminary work was completed using a batch water bath and a water bath and lock hopper arrangement. The slag pit geometries tested are included pictorially in Figure 7.

The water flush slag pit was modified to enhance the heating capacity of the slag tap hole. An illustration of the slag tap and water bath designated as Design \#4 is shown in Figure 7) with other slag tap geometries tested. The design was modified by increasing the distance from the slag tap to the water line, by inserting radiant heat shields directly below the slag tap, and by modifying the slag tap torches to allow continuous operation. This slag tap configuration was tested in TSSC No. 47. Operating conditions and test results are summarized in Tables 3 and 4. Table 4 also includes data taken in TSSC Tests Nos. 45 and 46 for comparison.

Testing was completed in the TSSC configured as illustrated in Figure 8. This configuration had required that the height of the primary zone be decreased from 24 inches to 16 inches. The height was decreased because of limitations of the test facility. A decrease in primary zone height results in less available combustion residence time. In past tests slag capture was influenced the greatest by decreased primary zone height.

Test No. 47 lasted for two hours on CWM. The slag tap torches were operated throughout the test while buming DF\#2 and CWM using a natural gas input pressure drop of 57 psid. The torches used primary air at $620^{\circ} \mathrm{F}$ and $4 \%$ pressure drop. A thermocouple measuring slag tap gas temperature reached a maximum of $2600^{\circ} \mathrm{F}$ before switching to CWM. Refractory wall temperatures measured at the impactor and below the slag tap reached maximums of $2483^{\circ} \mathrm{F}$ and $2049^{\circ} \mathrm{F}$, respectively. The water flush system was operated six times yielding 3 to $5 \mathrm{lbs}$ of slag. The slag collected in the lock hopper was largely in the form of pellets. 

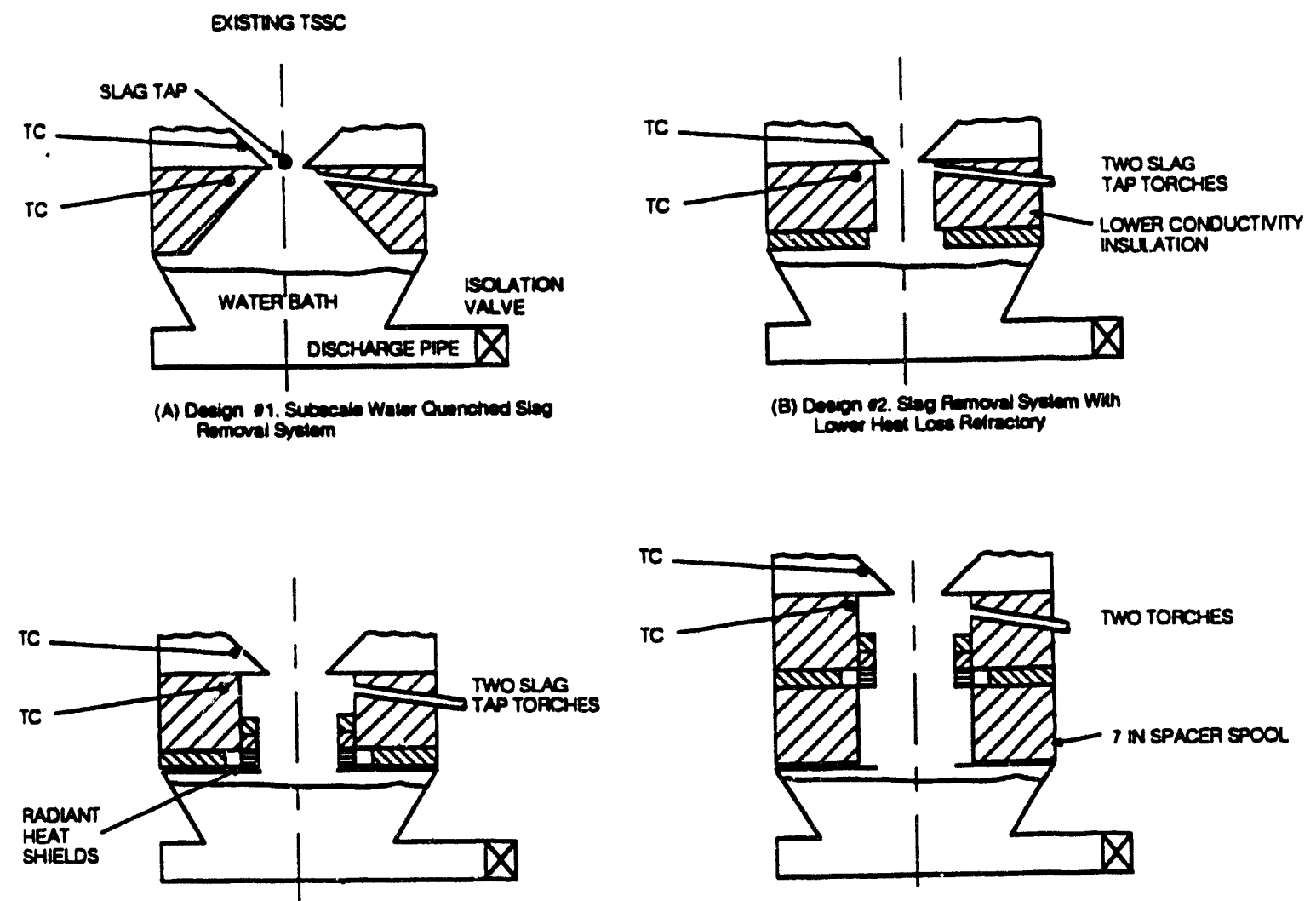

(C) Deaion 13 . Slag Renoval Syatem With Redient Heal Shields

(D) Decion 44. Sleg Removal Syatem Win Larger Steb Tap To Waver Bath Dietanco

Figure 7. Slag Removal System

In post test inspection the primary zone and injectors were in good shape, but the impactor showed some erosion. The area below and around the impactor was coated with slag but was free of any accumulations indicating that adequate temperatures in the region above the slag tap were achieved to insure slag flow. A total of $5.8 \mathrm{lbs}$ of slag was collected in the lock hopper and water bath. A 2.25 Ib piece of slag was bridged across the radiant heat shields below the slag tap. Apart from this slag bridge the remainder of the insulation comprising the radiant heat shields was free from slag. The slag bridge may be a result of the torch gas flow but this is unknown. This problem can be averted in the full scale design by slightly increasing the insulating inside diameters below the slag tap. The total slag capture has dropped to $45 \%$ with this TSSC configuration. The drop in slag capture was attributed to the decrease in primary zone height as described earlier.

This test concluded the design investigations of the continuous slag removal system. In this test successful slag tap heating was achieved through the use of slag tap torches. Nearly all the slag separated in the primary zone flowed through the slag tap. The slag collected in the water was small enough to be handled by a moderately sized purge valve and lock hopper. The system used in this test demonstrated removal of 50 to $75 \%$ of the slag collected by the impactor into a lock hopper from the primary zone. This was accomplished despite the design limitations which had the slag collect in a pipe with a large dead space unaffected by purging. 
Table 3. Summary of CWM Testing of Fuels of Varying Properties

\begin{tabular}{|c|c|c|c|c|c|}
\hline Teet No. & 48 & 49 & 50 & 51 & 52 \\
\hline $\begin{array}{l}\text { CWM } \\
\text { (critical property) }\end{array}$ & "S1" & $\begin{array}{l}\text { "S3" } \\
\text { (High Coal Load) }\end{array}$ & (Low Coal Load) & $\begin{array}{l}\text { "S6" } \\
\text { (med. ash) }\end{array}$ & $\begin{array}{l}\text { "S7" } \\
\text { (high ash) }\end{array}$ \\
\hline$T_{n}(\cdot F)$ & 653 & 652 & 625 & 626 & 639 \\
\hline$P_{n}$ (psig) & 79.5 & 78.4 & 75.7 & 76.7 & 76.0 \\
\hline$\phi_{\text {pumany }}$ & 1.42 & 1.43 & 1.55 & 1.47 & 1.36 \\
\hline$\triangle P P(\%)$ & 3.9 & 3.9 & 4.1 & 4.0 & 4.1 \\
\hline $\begin{array}{l}\text { Hoat Input } \\
\text { (MMBtu/hr) }\end{array}$ & 4.66 & 4.71 & 4.67 & 4.36 & 4.20 \\
\hline$T_{\text {and }}\left(P^{\circ} F\right)$ & 1962 & 2107 & 2107 & 1997 & 1968 \\
\hline \multicolumn{6}{|l|}{ BESULTS } \\
\hline \multicolumn{6}{|l|}{ Emlasions $\odot 15 \% \mathrm{O}_{2}$} \\
\hline $\begin{array}{l}\mathrm{NO}_{\mathrm{x}} \text { (pprrmv) } \\
\text { (lbmMMBtu) }\end{array}$ & $\begin{array}{c}53.3 \\
(0.2225)\end{array}$ & $\begin{array}{c}68.1 \\
(0.3040)\end{array}$ & $\begin{array}{c}86.3 \\
(0.3885)\end{array}$ & $\begin{array}{c}71.70 \\
(0.3050)\end{array}$ & $\begin{array}{c}67.23 \\
(0.2880)\end{array}$ \\
\hline $\begin{array}{l}\text { CO (ppmi; } \\
\text { (lbmMMBtu) }\end{array}$ & $\begin{array}{c}6.1 \\
(0.0155)\end{array}$ & $\begin{array}{c}3.2 \\
(0.00 \% 3)\end{array}$ & $\begin{array}{c}7.6 \\
(0.0204)\end{array}$ & $\begin{array}{c}12.9 \\
(0.0344)\end{array}$ & $\begin{array}{c}11.8 \\
(0.0304)\end{array}$ \\
\hline $\begin{array}{l}\mathrm{so}_{2} \text { (ppmv) } \\
\text { (lbmMMBtu) }\end{array}$ & NA & $\begin{array}{c}178 \\
(1.064)\end{array}$ & $\begin{array}{c}107 \\
(0.6664)\end{array}$ & NA & $\begin{array}{c}257 \\
(1.5323)\end{array}$ \\
\hline Particulate (ppmm) & 2034.1 & 455.2 & 1584.9 & 1167.2 & 750.2 \\
\hline Carbon Convereion (\%) & 97.2 & 99.7 & 97.2 & 99.0 & 89.8 \\
\hline \multicolumn{6}{|l|}{ Ash Balance } \\
\hline $\begin{array}{l}\text { Primary Zone Slag Capture } \\
\text { (\%) }\end{array}$ & 37.2 & 23.9 & 28.9 & 26.0 & 46.0 \\
\hline Ash Emitted (\%) & 92.9 & 26.7 & 53.6 & 24.2 & 14.8 \\
\hline $\begin{array}{r}\text { Imbalance (\%) } \\
\text { (lbs) }\end{array}$ & $\begin{array}{l}-30.1 \\
-5.8 \\
\end{array}$ & $\begin{array}{l}49.3 \\
10.0\end{array}$ & $\begin{array}{l}17.4 \\
4.63 \\
\end{array}$ & $\begin{array}{l}49.3 \\
24.2 \\
\end{array}$ & $\begin{array}{l}39.1 \\
39.4\end{array}$ \\
\hline
\end{tabular}


Table 3. Summary of CWM Testing of Fuele of Varying Properties (Continued)

\begin{tabular}{|c|c|c|c|c|c|c|}
\hline Test No. & 53 & 54 & 55 & 56 & 57 & 58 \\
\hline $\begin{array}{l}\text { CWM } \\
\text { (critical property) }\end{array}$ & $\begin{array}{c}\text { "S5" } \\
\text { (no additives) }\end{array}$ & $\begin{array}{c}\text { "S8" } \\
\text { (fine grind) }\end{array}$ & $\begin{array}{c}\text { "Sg" } \\
\text { (coaree grind) }\end{array}$ & $\begin{array}{l}\text { "S10" } \\
\text { (Upper } \\
\text { Freeport) }\end{array}$ & $\begin{array}{l}\text { "S11" } \\
\text { (Soldier } \\
\text { Creok) }\end{array}$ & $\begin{array}{l}\text { "S12" } \\
\text { (IIllinola } \\
\text { No. 6) }\end{array}$ \\
\hline$T_{n}\left({ }^{\circ} F\right)$ & 624 & 624 & 628 & 654 & 627 & 618 \\
\hline$P_{n}$ (psig) & 79.9 & 76.1 & 79.7 & 76.0 & $\pi 7.0$ & 76.0 \\
\hline$\phi_{\text {manor }}$ & 1.297 & 1.40 & 1.50 & 1.44 & 1.42 & 1.36 \\
\hline$\triangle P \mathbb{P}(\%)$ & 3.90 & 4.0 & 4.0 & 3.9 & 4.0 & 4.10 \\
\hline $\begin{array}{l}\text { Heat Input } \\
\text { (MMBtu/hr) }\end{array}$ & 4.46 & 5.66 & 4.95 & 4.11 & 4.52 & 4.48 \\
\hline$T_{\max }\left({ }^{\circ} F\right)$ & 1794 & 2001 & 2038 & 1971 & 2011 & 1970 \\
\hline \multicolumn{7}{|l|}{ BFEULTS } \\
\hline \multicolumn{7}{|l|}{ Emisalons $\odot 15 \% \mathrm{O}_{2}$} \\
\hline $\begin{array}{l}\text { NO } \text { (pprmv) } \\
\text { (lbmMMBtu) }\end{array}$ & $\begin{array}{c}81.90 \\
(0.3833)\end{array}$ & $\begin{array}{c}70.15 \\
(0.3100)\end{array}$ & $\begin{array}{c}65.20 \\
(0.2850)\end{array}$ & $\begin{array}{c}55.40 \\
(0.2783)\end{array}$ & $\begin{array}{l}5.2 .00 \\
(0.2350)\end{array}$ & $\begin{array}{c}43.80 \\
(0.2100)\end{array}$ \\
\hline $\begin{array}{l}\text { CO (ppmv) } \\
\text { (brmMiMBtu) }\end{array}$ & $\begin{array}{c}109.7 \\
(0.3127)\end{array}$ & $\begin{array}{c}19.8 \\
(0.0540)\end{array}$ & $\begin{array}{c}11.7 \\
(0.0310)\end{array}$ & $\begin{array}{c}20.9 \\
(0.0637)\end{array}$ & $\begin{array}{c}15.9 \\
(0.0450)\end{array}$ & $\begin{array}{c}23.5 \\
(0.2110)\end{array}$ \\
\hline $\begin{array}{l}\mathrm{SO}_{2} \text { (ppmv) } \\
\text { (IbmMMBtu) }\end{array}$ & $\begin{array}{c}156 \\
(1.0081)\end{array}$ & $\begin{array}{c}156.1 \\
(0.9461)\end{array}$ & $\begin{array}{c}84.7 \\
(0.5250)\end{array}$ & $\begin{array}{l}129.0 \\
(0.9095)\end{array}$ & NA & $\begin{array}{c}40.7 \\
(0.2730)\end{array}$ \\
\hline Particulate (ppmm) & 747.0 & 1038.7 & 872.0 & 169.6 & 235.5 & 1076.1 \\
\hline Carbon Conversion (\%) & 98.4 & 97.9 & 98.5 & 99.8 & 99.6 & 98.1 \\
\hline \multicolumn{7}{|l|}{ Aeh Balance } \\
\hline $\begin{array}{l}\text { Primary Zone Slag } \\
\text { Capture (\%) }\end{array}$ & 22.0 & 21.0 & 18.0 & 31.0 & 23.0 & 54.0 \\
\hline Ash Emitted (\%) & 25.8 & 28.4 & 25.1 & 3.2 & 7.4 & 20.8 \\
\hline $\begin{array}{c}\text { Imbalance (\%) } \\
\text { (lbs) }\end{array}$ & $\begin{array}{r}9.5 \\
52.2\end{array}$ & $\begin{array}{c}51.0 \\
(15.1)\end{array}$ & $\begin{array}{r}57.4 \\
(16.9)\end{array}$ & $\begin{array}{l}65.9 \\
42.8\end{array}$ & $\begin{array}{l}69.2 \\
24.8 \\
\end{array}$ & $\begin{array}{c}19.6 \\
9.4\end{array}$ \\
\hline
\end{tabular}


Table 4. Summary of TSSC Combustor Testing of Slag Removal Syetem

\begin{tabular}{|c|c|c|c|}
\hline Test No. & 45 & 46 & 47 \\
\hline Slag Design & 1 & 2 & 4 \\
\hline CWM & $T$ & $T$ & $T$ \\
\hline$T_{n}\left({ }^{\circ} \mathrm{F}\right)$ & 638 & 636 & 644 \\
\hline$P_{h}$ (psig) & 76 & 75 & 61 \\
\hline$T_{\text {and }}\left({ }^{\circ} \mathrm{F}\right)$ & 1933 & 1960 & 1798 \\
\hline$\Phi_{\text {primery }}$ & 1.39 & 1.37 & 1.38 \\
\hline $\begin{array}{l}\mathrm{NO}_{\mathrm{x}} \text { (ppm) } \\
(\mathrm{bmMMBtu})\end{array}$ & $\begin{array}{c}49.0 \\
(0.1976)\end{array}$ & $\begin{array}{c}48.8 \\
(0.1950)\end{array}$ & $\begin{array}{c}44.3 \\
(0.1781)\end{array}$ \\
\hline $\begin{array}{l}C O \text { (ppm) } \\
\text { (lbm/MMBtu) }\end{array}$ & $\begin{array}{c}2.6 \\
(0.0068)\end{array}$ & $\begin{array}{c}2.2 \\
(0.0050)\end{array}$ & $\begin{array}{c}4.3 \\
(0.0103)\end{array}$ \\
\hline $\begin{array}{l}\Delta P / P \text { Primary } \\
(\%)\end{array}$ & 4.1 & 4.0 & 4.0 \\
\hline $\begin{array}{l}\text { Slag Capture } \\
\text { (wt\%) }\end{array}$ & 70 & - & 45 \\
\hline $\begin{array}{l}\text { Heat Input } \\
\text { (MMBtu/hr) }\end{array}$ & 4.70 & 5.08 & 4.03 \\
\hline
\end{tabular}

As a summary the follow..ig are important observations and design criteria that will be useful in full scale slag removal system design:

1) The presence of a water bath below the primary zone has no detectable impact on the operation of the combustor.

2) Slag that was quenched in a water bath after dripping through a slag tap was largely in the form of slag pellets of 0.25 to 0.325 inch diameter. The slag was very brittle and easily crushed by hand. This information indicates that an auger/crusher was not necessary.

3) In subscale testing slag tap heating was required for the slag to flow through the slag tap. In the full scale this may not be true because of the decreased surface area to volume ratio and the increased slag flow rate. The design of the slag tap heating arrangement is a critical part of the system.

4) An isolation valve can be used to purge most of the slag from the water bath into a lock hopper with no noticeable impact on the system.

5) Design of the passage from the slag tap to the water bath must be sufficiently large to prevent slag bridging while minimizing heat loss. 


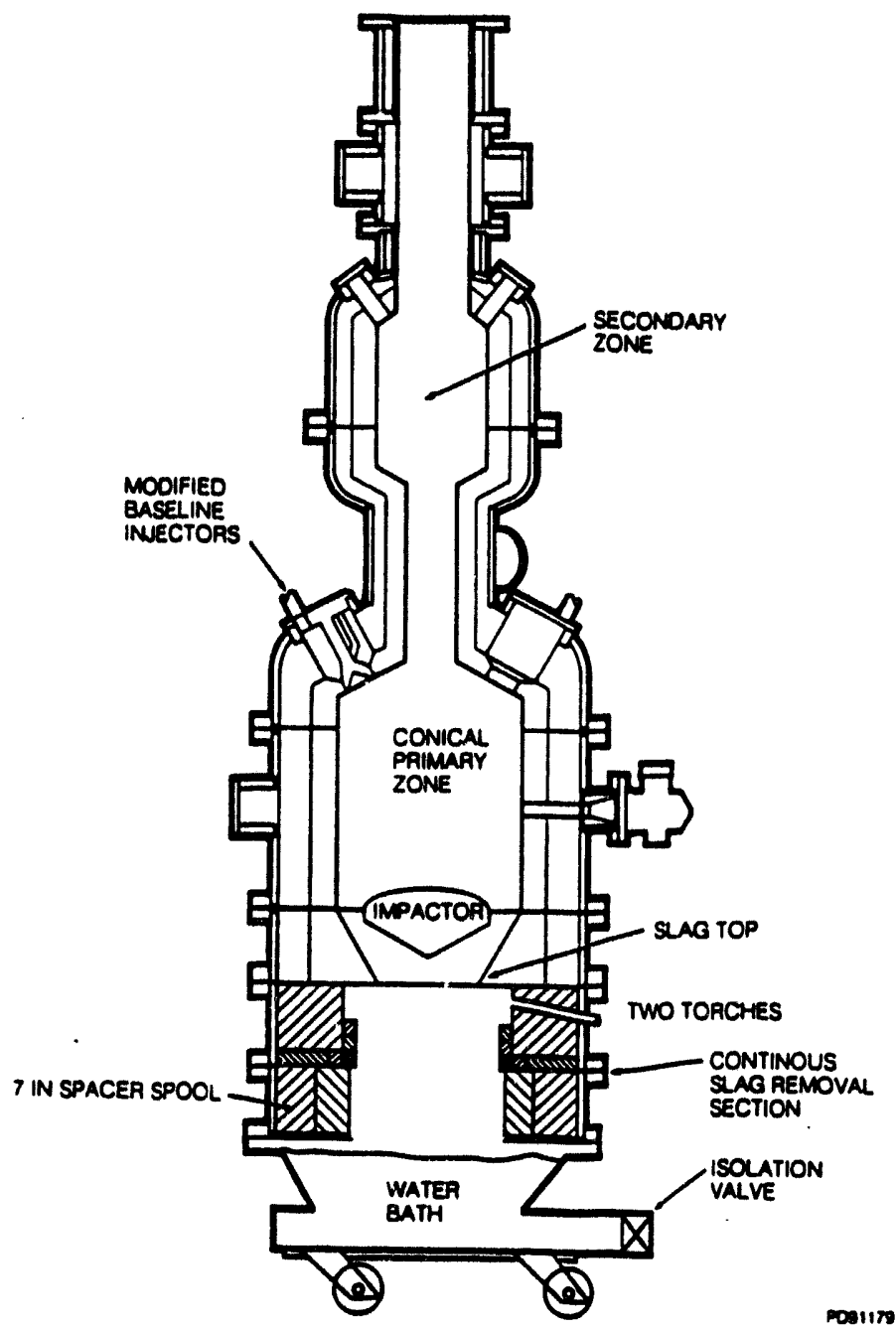

Figure 8. TSSC Test configuration for Evaluation of Fuels of Varying Properties

\subsection{CRUDE OIL EVALUATION}

One of the claims for the combustion system being developed on this contract is that it is adaptable to other fuels including crudes and residuals. Tests were performed using the Two-Staged Slagging Combustor (TSSC) and a crude oil from Califomia's San Joaquin Valley to verify the claim. This crude is fairly heavy, therefore if it can be bumed satisfactorily, then most other crude oils can be bumed.

In order for the crude to flow easily through the delivery piping, barrel heaters were used to heat the fuel prior to the injectors. A typical fuel temperature of $165^{\circ} \mathrm{F}$ was maintained. Diesel \#2 was used as a pilot fuel to heat the rig. The time on pilot fuel was substantially shorter compared to burning CWM, because of the lower ignition temperature for crude. Since it was not necessary to get the primary zone walls up to the usual $2400^{\circ} \mathrm{F}$ on diesel, as required for CWM ignition, approximately two hours were spent on heating the rig prior to fuel changeover for each test. 
In Test 1 the rig was smoothly changed over to crude, and ran for approximately 50 minutes before a leak formed in the primary zone causing a rapid shutdown. Attempting to run a range of fuel flow: to characterize the combustor on crude, it was discovered that the fuel delivery system did not respond well at low fiows. Several data points were taken with the equivalence ratio ranging, on the rich side, from 1.58 to 1.83. Primary zone temperatures were approximately $2500^{\circ} \mathrm{F}$, while transition zone temperatures were around $1900^{\circ} \mathrm{F}$. The secondary combustion zone remained unusually cool throughout the test running between 600 to $800^{\circ} \mathrm{F}$.

Post-test inspection revealed a melted primary zone. Most of the refractory had flowed down the side walls, at some points exposing the outer steel skin. The refractory settled in the impactor section, although the impactor was still visible and in excellent condition. It appears that some reaction took place between the coal-slag coated refractory and the crude effluent at a critical temperature. Since the impactor was recovered with no damage, it was used for the following test.

Disassembling the rig and looking at the injector section, some degradation of the outer sleeve of one of the injectors was found. Figure 9 shows the injector section after the first crude oil test. Shown in Figure 10 is the injector with a small hole on the side near the weld and the faces of two injectors showing the centered fuel and air assist passage and the build-up around the primary air holes. A new conical piece was fabricated and rewelded to the sleeve. The reasch for this rupture is not known but expected to be caused from over-temperature. The remaining injectors were in good condition.

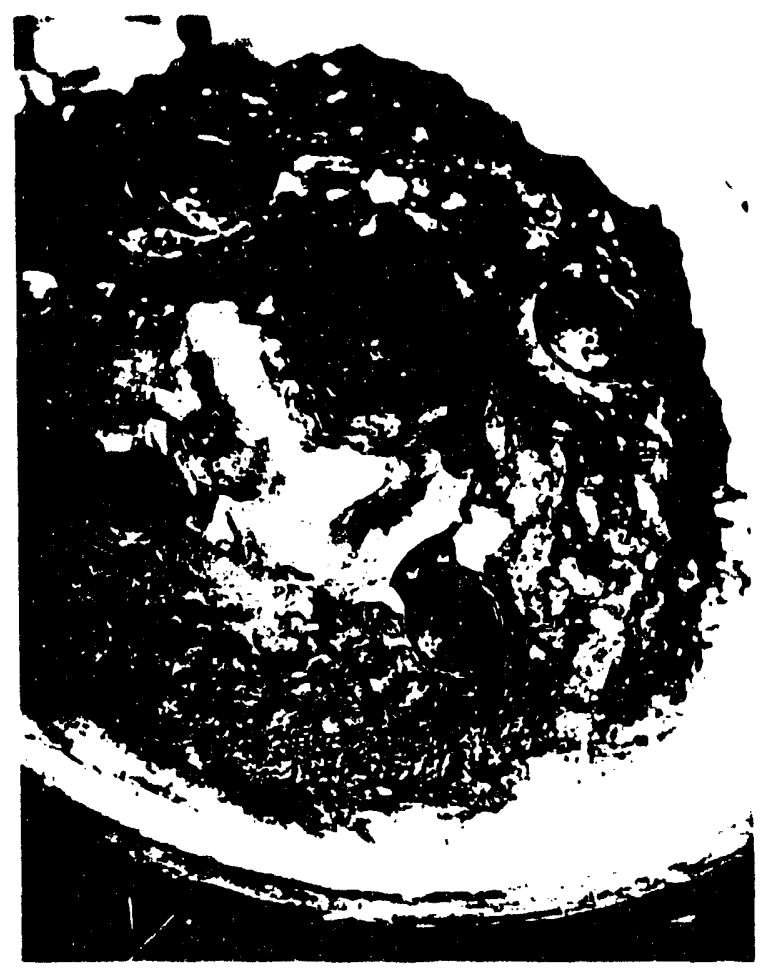

Figure 9. Primary Injector Section After the TSSC Crude Oll Test 


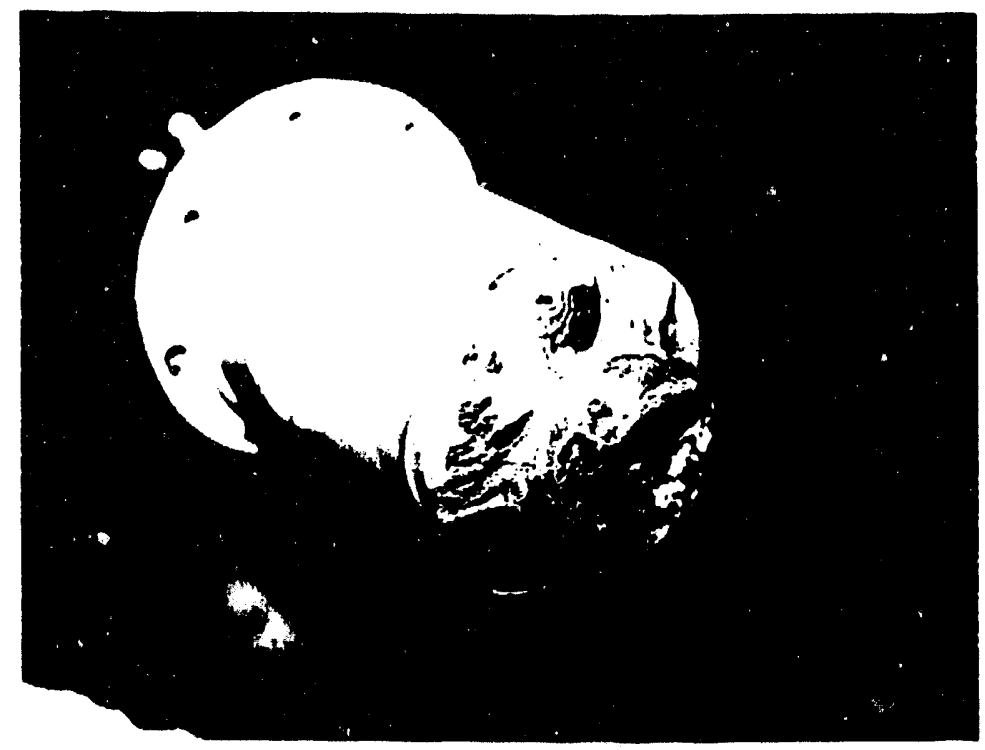

(A)

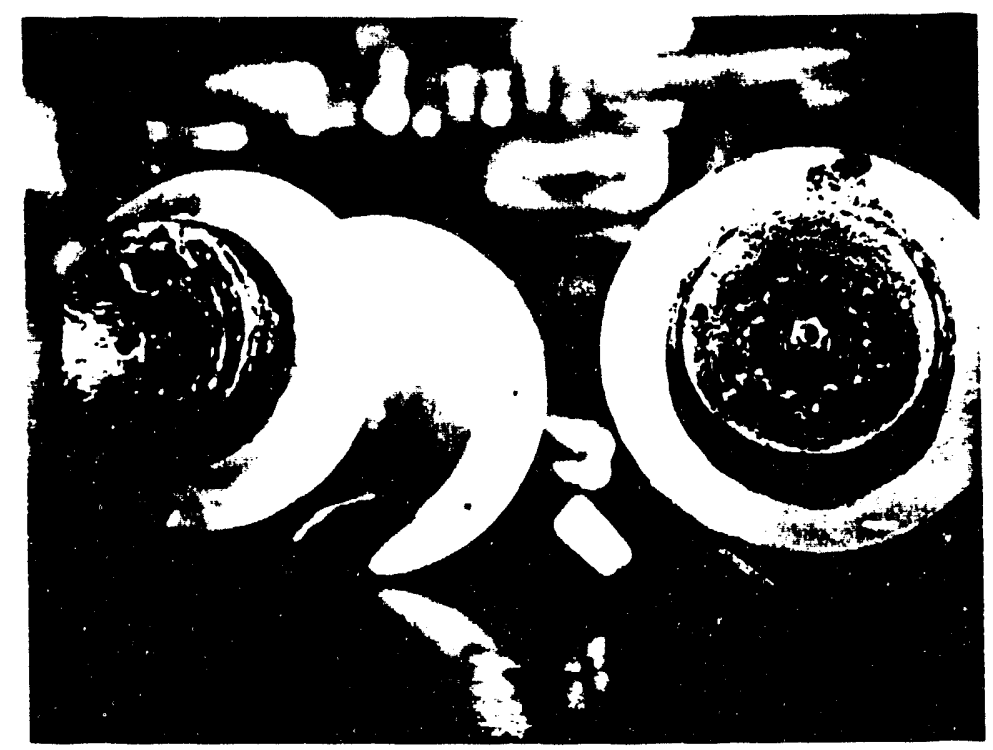

(B)

Figure 10. A) Hole Near Weld on Primary Zone Injector; B) Injector Face

New primary, secondary, and transition zones were fabricated and testing continued. In Test 2, the diesel start was very smooth as was the switch to crude and temperatures quickly increased. The equivalence ratio was varied as much as possible and emission points were taken. Since this was the first test using the effervescent atomizer, the air assist was also varied to observe any effect on combustor performance and emissions. 
While varying equivalence ratio, primary zone wall temperatures ranged from 2443 to $2662^{\circ} \mathrm{F}$ while secondary outlet temperatures ranged from 1417 to $2052^{\circ} \mathrm{F}$. In light of extraordinarily high crude oil pump pressures, above the 600 psig maximum of the gauge, rig pressure was decreased to 60 psig in order to continue the test at near design conditions. Emissions data shown in Table 5 were typical, operating in $\mathrm{O}_{2}$ ranges of 13.2 to $16.4 \%$. Data shown is corrected to $15 \%$ oxygen. Figure 11 shows how the NOx is effected by varying the equivalence ratio and the air assist pressures at the injector. The graph in Figure 12 illustrates how well the combustor periormed showing the primary zone equivalence ratio versus the measured $0^{\circ}$.ygen content in the exhaust.

Given the high temperatures and limited fuel and rig pressure ranges, approximately 375 pounds of crude oll was bumed. Toward the end of the run, instead of the usual switch over to diesel, diesel was pumped into the holding tank containing the remaining crude oil with the expectation of simultaneously flushig out the fuel system lines and reducing the temperature of the rig. No fuel density nor temperature change was observed, therefore the fuels must have co-mingled in the tank.

Preliminary inspection revealed clean, intact primary zone walls, impactor section, and residence section. However, the face of one injector, which was removed for inspection, was badly bumt, stripping away the primary air weld around the annulus. Also, a relatively large amount of soot was sturk to the fuel port exit. One injector was flowed with water for a visual inspection. The spray was skewed off center and a strong jet steamed the center of the spray. Albeit, good atomization was observed. It is presumed that although primary air escaped from the broken weld, the injectors yielded a fair performance.

Table 5. Emissions Data From TSSC Crude Oll Test 2

\begin{tabular}{|c|c|c|c|c|c|c|}
\hline \multicolumn{7}{|c|}{$\begin{array}{c}\text { All Data Taken at DP/P }=3.8 \% \\
\text { PPRI = 63 psig }\end{array}$} \\
\hline $\begin{array}{c}\text { W Fuel } \\
\text { (pph) }\end{array}$ & $\begin{array}{c}\text { Pres AA } \\
\text { (palg) }\end{array}$ & PHI & O $_{2} \%$ & $\begin{array}{c}\text { NOx } \\
\text { (ppm) }\end{array}$ & $\begin{array}{c}\text { Co } \\
\text { (ppm) }\end{array}$ & $\begin{array}{c}\text { UHC } \\
\text { (ppm) }\end{array}$ \\
\hline 152 & 150 & 1.35 & 15.89 & 124.8 & 16 & 7.4 \\
145 & 150 & 1.25 & 15.97 & 161.8 & 14.9 & 7.7 \\
140 & 150 & 1.43 & 16.38 & 283.6 & 15.5 & 8.4 \\
136 & 150 & 1.4 & 16.57 & - & 15.5 & 9.4 \\
132 & 150 & 1.18 & 16.72 & 494.8 & 15.3 & 9.7 \\
186 & 150 & 1.72 & 15.09 & 145.7 & 11.6 & 5.7 \\
211 & 170 & 1.87 & 14.05 & 166.2 & 8.9 & 5 \\
218 & 190 & 1.94 & 13.3 & 172.7 & 7.3 & 4.5 \\
228 & 210 & 1.92 & 12.79 & -1.3 & 6.7 & 4.6 \\
211 & 214 & 1.76 & 13.54 & 164.4 & 7.4 & 4.8 \\
204 & 210 & 1.72 & 13.94 & 138.8 & 7.8 & 5.3 \\
190 & 212 & 1.82 & 14.39 & 107 & 9.5 & 6.4 \\
181 & 212 & 1.58 & 14.53 & 117.4 & 8.5 & 5.4 \\
153 & 212 & 1.54 & 15.4 & 107.2 & 10.1 & 6.2 \\
\hline
\end{tabular}




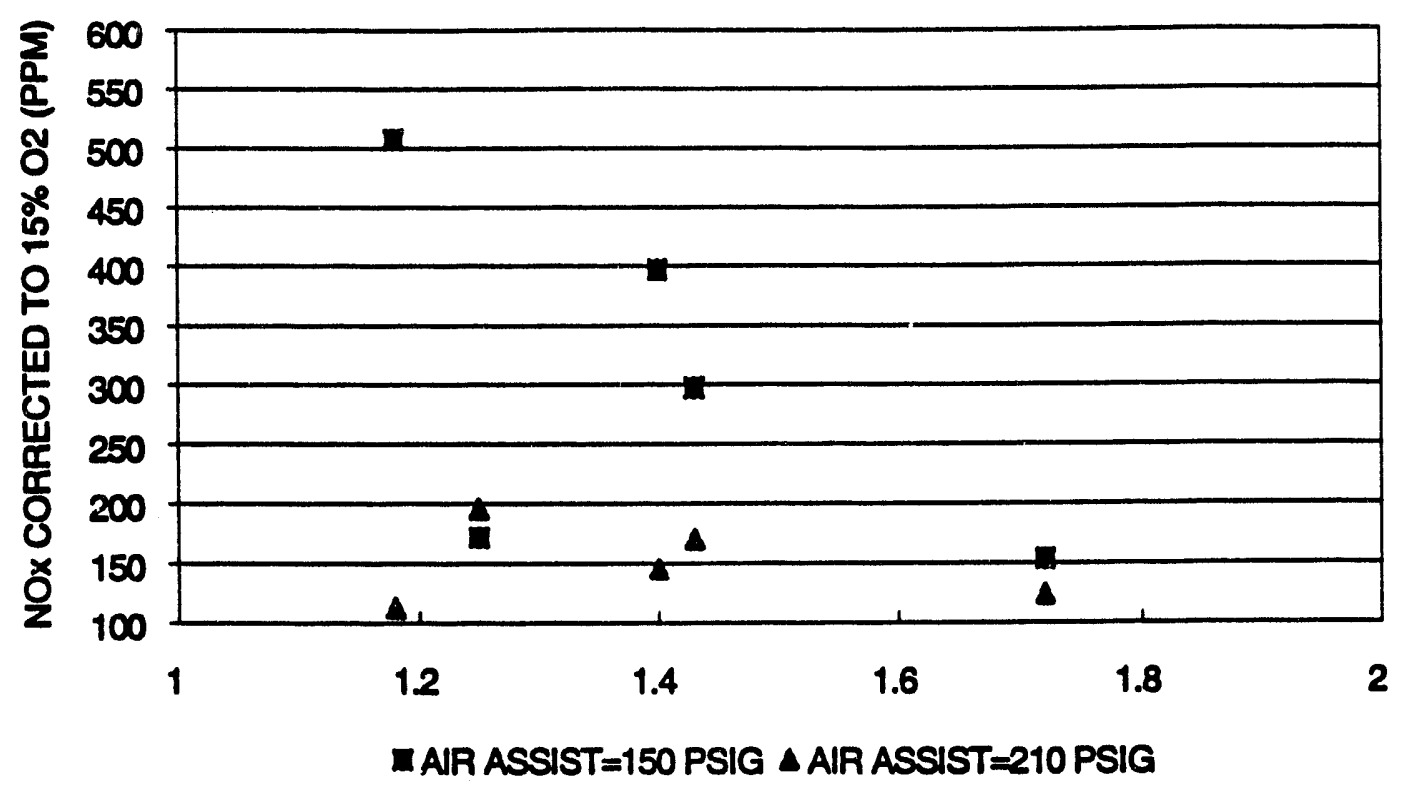

Figure 11. Effects of Varied Alr Assist Pressures on NOx

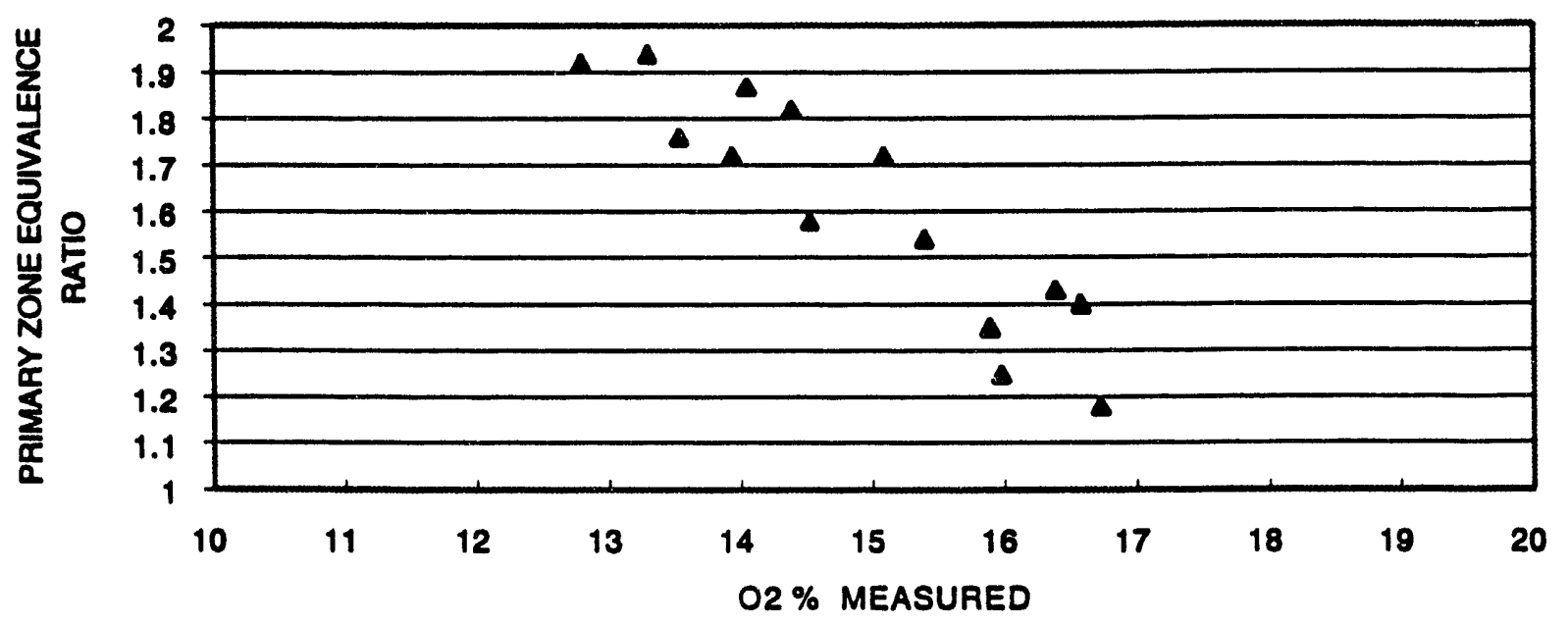

Figure 12. Combustor Performance Shown by Primary Zone Equivalence Ratio ve. Measured Oxygen in the Effluent 


\subsection{SULFUR OXIDE REMOVAL}

Sulfur in coal exists as organic sulfur and inorganic sulfur (primarily pyrite $\mathrm{FeS}_{2}$ ). The organic sulfur may occur as side-chains to the hydrocarbon ring structure and as thiophene compounds within the ring structure. The latter form appears to be dominant. Upon injection into the primary zone of a coal combustor the coal particles undergo devolatilization to aromatic, aliphatic, and inorganic sulfur compounds. Thermal and reductive decomposition of pyrite is expected to yield sulfur $\left(S_{2}\right)$, hydrogen-sulfide $\left(\mathrm{H}_{\mathrm{s}}\right)$, and carbon! / sulfide (COS). Experiments have shown that organic sulfur also gives a fair yield of light gas; the remainder being sulfur condensibles. Hydrogen sulfide appears to be an important light gas from coal devolatilization. The combustion literature abounds with studies on sulfurous flames and reactors. However information on the concentration and chemical kinetics of fuel-sulfur in hydrocarbon combustion systems is incomplete. The gas-phase composition about coal particles is predominantly a mix of hydrocarbon and air. The fuel-air equivalence ratio varies from fuel-rich near the coal particle to possibly fuel-lean in the main gas stream. In addition, sulfur release from coal devolatilization can be inhibited by inherent capture of coal-bound mineral matter, particularly calcium oxides and sodium oxides:

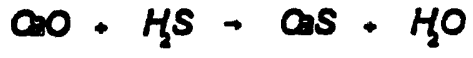

which in the slagging combustor design may be removed with the slag. Thus, the fate of the fuelsulfur in this zone is not well understood.

In a staged combustion system where the primary zone is fuel-rich to minimize the formation of NO from fuel-bound nitrogen, the sulfur species produced during the various reactions are predominantly $\mathrm{H}_{2} \mathrm{~S}, \mathrm{COS}$, and carbon disulfide $\left(\mathrm{CS}_{2}\right)$. These compounds are, however, quickly oxidized in the lean secondary to sulfur dioxide and a smaller amount of sulfur trioxide which is then emitted in the exhaust.

The oxides of sulfur resulting from direct coal-fired combustion can be reduced by three different processes:

(1) Sulfur removal from the coal prior to combustion

(2) Sulfur removal during the combustion process by sorbent materials

(3) Exhaust scrubbing systems.

Physical cleaning of coal can be very effective in removing inorganic sulfur, especially pyrite. However, to achieve sulfur levels in the coal to meet anticipated sulfur emission requirements, a combination of physical and chemical coal cleaning is required, and these processes are very costly.

Exhaust scrubbing systems are being used in the coal-fired utilities but are also expensive due to the large scale of the necessary components.

Work done exploring the use of dry calcium-based sorbents in coal-fired utility boilers indicate that significant reductions in $\mathrm{SO}_{\mathbf{x}}$ can be achieved. Gas turbine combustion differs from utility boiler combustion in two ways: (1) residence times in the gas turbine combustor are much smaller and, (2) pressures are much higher. Shorter residence times are a disadvantage for $\mathrm{SO}_{\mathrm{x}}$ absorption while increased pressure helps promote a Ca-S reaction. 
Richard Newby of Westinghouse R\&D was retained to consult on the desulfurization of Solar's coalfired combustor exhaust stream. Discussions were held in six different areas: sorbent injection location, sorbent type, kinetic modeling evaluation, measurement techniques, sulfur removal influence on the total system, and integrated sulfur removal with particulate control.

The secondary zone, injecting with secondary air, is the probable best location for sorbent injection for the Solar test work. It may be found that excessive sintering occurs at this location, in which case injection downstream of the secondary zone will be preferred. While the Solar test unit will have limited particle residence time downstream of the secondary zone, and high efficiency removal may not be possible in the test unit, commercial designs may use high-temperature filters that add considerable residence time and make the down-stream injection even more effective. The primany zone injection is complex and should only be attempted if a major development effort can be established. A fluidized bed desulfurizer stage following the secondary zone is an attractive backup to fine sorbent injection.

The overall choice of sorbent was, in reality, site and fuel specific to some extent. For the Solar testing the following sorbents are recommended: (1) Lime hydrate, (2) Hydrated dolomite (atmospheric or pressurized), and (3) Dolomite.

The approximate relative cost of these materials (relative to the cost of bulk limestone of a coarse, normal quarry size) per ton delivered is:

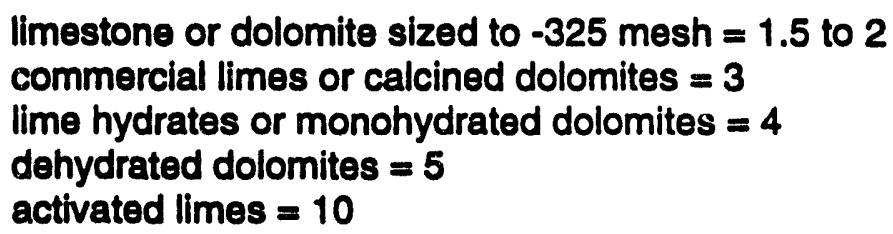

Additives to improve sorbent performance are currently being tested in atmospheric pressure systems. Performance improvements are not great, and such additives may introduce corrosive species into the turbine. Their use was not recommended.

Alternative sorbent materials can be identified that have the thermodynamic potential to remove sulfur in the Solar combustor. They are all at least an order-of-magnitude more expensive than calcium-based sorbents and required the use of complex sorbent regeneration processes to be economical. They should be considered only if calcium-based sorbents fail to be effective.

Salcium-based sorbents will not capture sodium or potassium released from coal in the combustor. In fact, the sorbents will generally be a source of alkali. The sodium contents of limestones and dolomites range from 0 to $2000 \mathrm{ppm}$, with most of it being in a soluble form. The potassium contents of limestones and processed sorbents (limes and hydrates) may be lower, but little data exist on this.

Sorbent injection into the slagging zone obviously has a great impact on the nature of the slagging phenomena and the properties of the slag formed. The T250 temperature is a common measure of the slag properties, and general criteria relating it to the sorbent feedrate have been proposed in the literature.

Measurements of $\mathrm{SO}_{2}$ reduction in the exhaust gases of the subscale two-stage slagging combustor through injection of calcium-based sorbents were made. An extension piece was added above the secondary zone of the TSSC as illustrated in Figure 13 to increase available reaction times between the calcium-based sorbents and $\mathrm{SO}_{2}$ laden exhaust gases. Measurements of $\mathrm{SO}_{2}$ concentration 


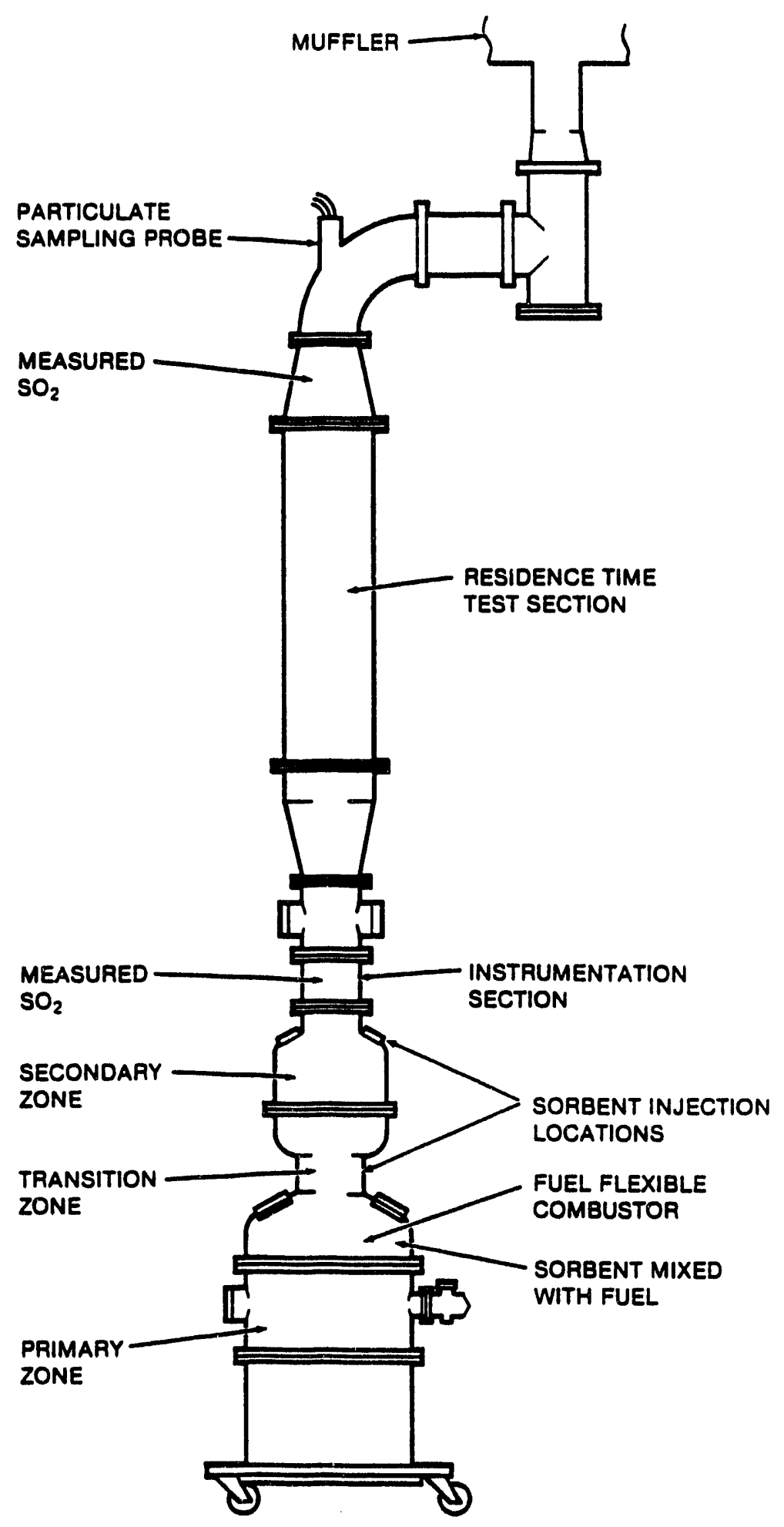

Figure 13. Sorbent Injection Experimental Test Set-up 
were made at the exit of the secondary zone and at the exit of the residence time test section. Sorbent was injected in the secondary zone with the incoming secondary air at only one port.

Sorbent was delivered via a dense-phase pneumatic sorbent feed system consisting of a delivery tube and feed tank. The feed tank is illustrated in Figure 14. Sorbent was conveyed up the delivery tube with a carrier gas (heated nitrogen) at mass ratios of 5-10 to 1 sorbent to carrier gas. This system and its operation have been described in detail elsewhere (Ref. 1).

Testing of the subscale coal-fueled combustor was aimed at evaluating sulfur removal effectiveness of powdered dolomite injection into the secondary zone. Sulfur dioxide reductions as high as $90 \%$ have been measured. $\mathrm{SO}_{2}$ reduction versus $\mathrm{Ca} / \mathrm{S}$ molar ratio is shown in Figure 15 for Tests Nos. 5 and 8. These tests were run at 80 psig and $620^{\circ} \mathrm{F}$ inlet air. Fuels Amax 'C' and Amax 'D' were bumed in Test 5 and 8 , respectively. Sulfur dioxide reductions are basen on the theoretical maximum $\mathrm{SO}_{2}$ level calculargd from the measured fueVair ratio and sulfur content of the parent coal. Figure 15 indicates that at $\mathrm{Ca} / \mathrm{S}$ ratios above 5.0 , more than $80 \% \mathrm{SO}_{2}$ reductions can be achieved. All $\mathrm{SO}_{2}$ measurements were taken at the exit of the extension piece on the secondary zone allowing approximately $200 \mathrm{msec}$ residence time for the sorbent particles to react with the exhaust gases.

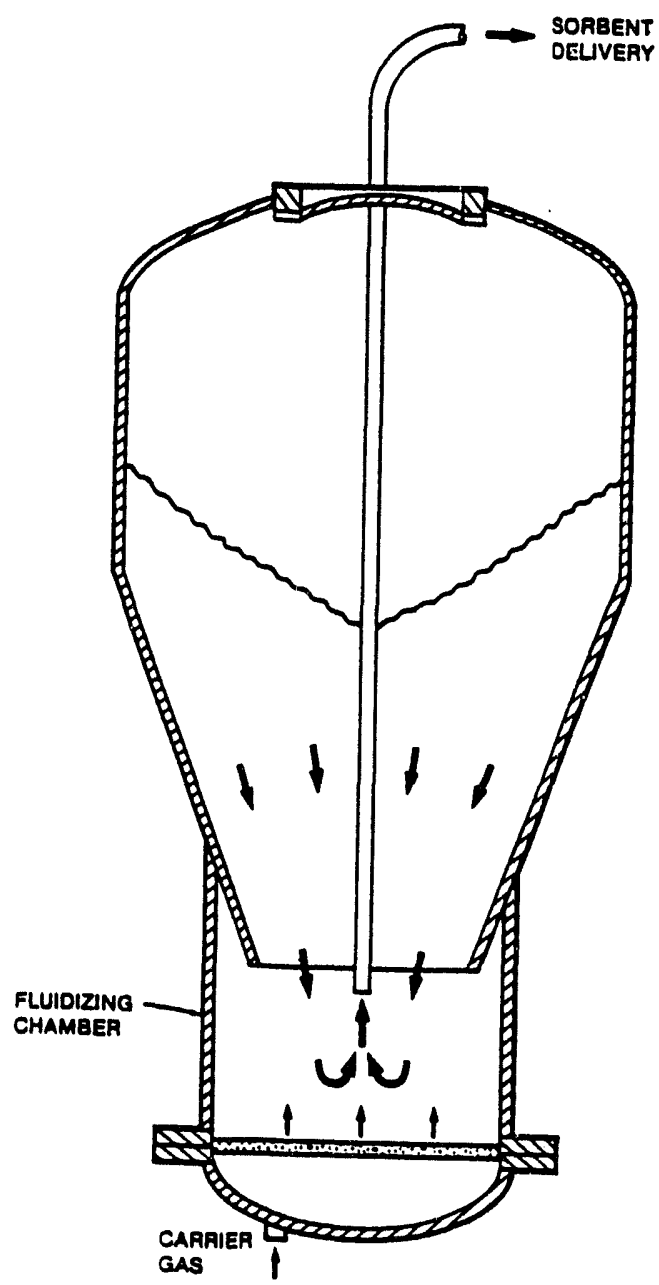

Flgure 14. Dense-Phase Pneumatlc Sorbent Feed Tank 


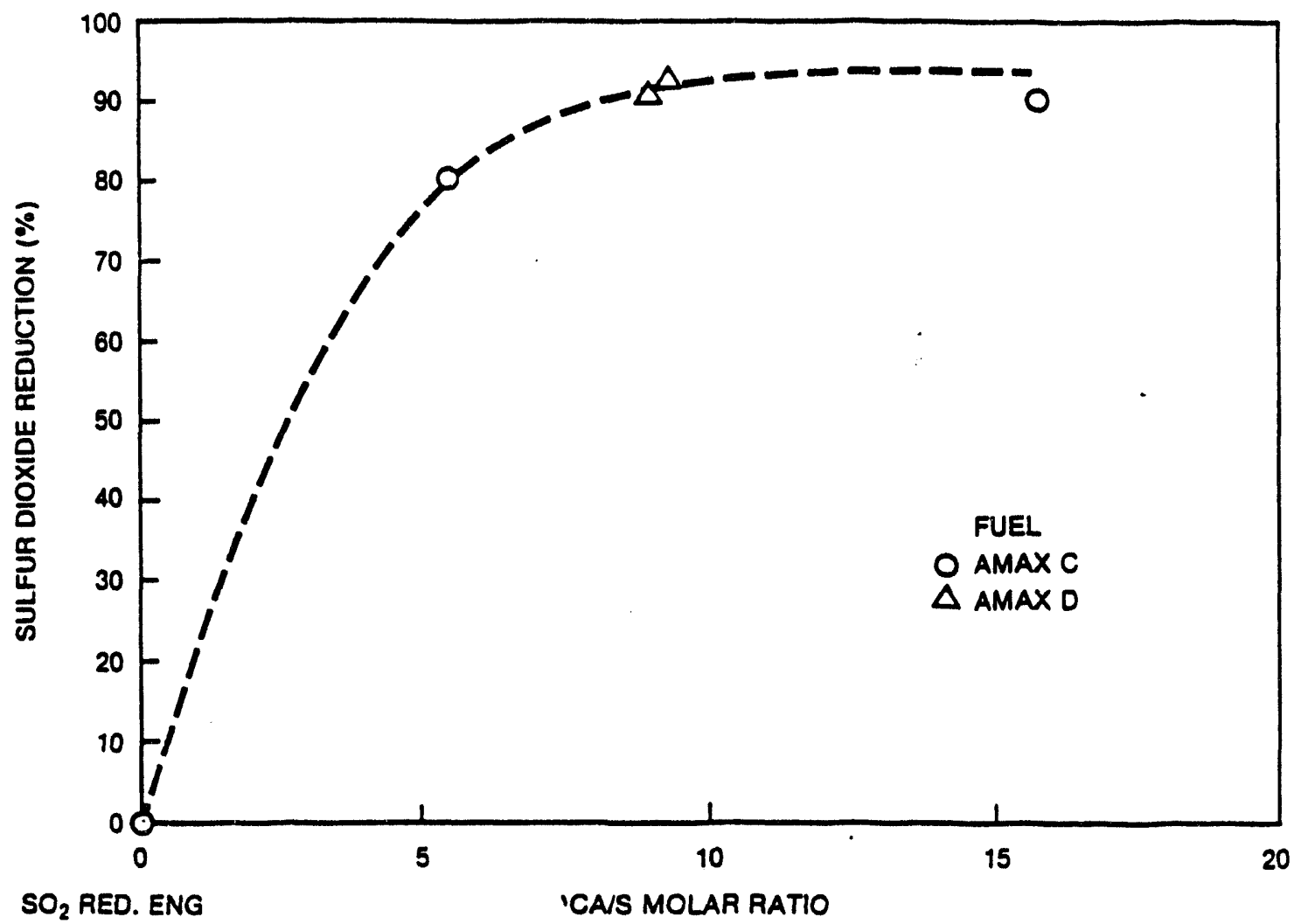

Figure 15. $\mathrm{SO}_{2}$ Reductlons for Dolomite Injected in the Secondary Zone

Actual emissions data from these tests are included in Figure 16. These data are taken at the exit of the residence time test section. $\mathrm{SO}_{2}$ emissions without sorbent injection vary with coal sulfur level as indicated in this figure. Comparison between measured and calculated $\mathrm{SO}_{2}$ emissions show excellent agreement with $\mathrm{Ca} / \mathrm{S}$ molar ratios greater than $5.0, \mathrm{SO}_{2}$ emissions can be reduced to less than $40 \mathrm{ppm} @ 15 \% \mathrm{O}_{2}$ with a 0.9 sulfur wt $\%$ i_el and to below $10 \mathrm{ppm} \odot 15 \% \mathrm{O}_{2}$ with a 0.56 sulfur wt\%.

Particulate sample collected during Test No. 5 was analyzed. The chemical analysis of the solid material and dilution water is included in Table 6. The sample was taken while injecting dolomite at a $\mathrm{Ca} / \mathrm{S}$ molar ratio of 5.5 The particulate analysis indicates little increase in sulfur concentration. Analysis of the dilution water shows a marked increase of sulfur in solution. The ash and dolomite analysis of the particulate are a combination of ash and spent sorbent.

SEM photographs of the raw dolomite and the spent sorbent and ash are included in Figures 17 and 18, respectively. The raw dolomite sample was a homogeneous crystalline structure with little visible porosity. SEM analysis, shown in Figure 17B, indicates the structure was largely calcium and magnesium. The spent sorbent and ash particulate pictured in Figure 18A was non-homogeneous, and three separate materials can be identified. The particulate was primarily large (greater than 10 microns), amorphous, slightly porous, unspent sorbent particles covered with small nodules of spent sorbent and flyash. SEM analyses of both the large particles and smaller nodules are shown in Figures $18 \mathrm{~B}$ and $18 \mathrm{C}$. Figure $20 \mathrm{~B}$ indicates little if any sulfur present, while Figure $18 \mathrm{C}$ indicates measurable quantities of sulfur and the constituents of coal ash ( $\mathrm{Al}, \mathrm{Si}, \mathrm{Fe}$, etc.). The third substance observed in the particulate is not pictured, but a SEM analysis of it is included in Figure 19. The material was spheroidal and regular with a smooth "glassy" surface. The analysis indicates 


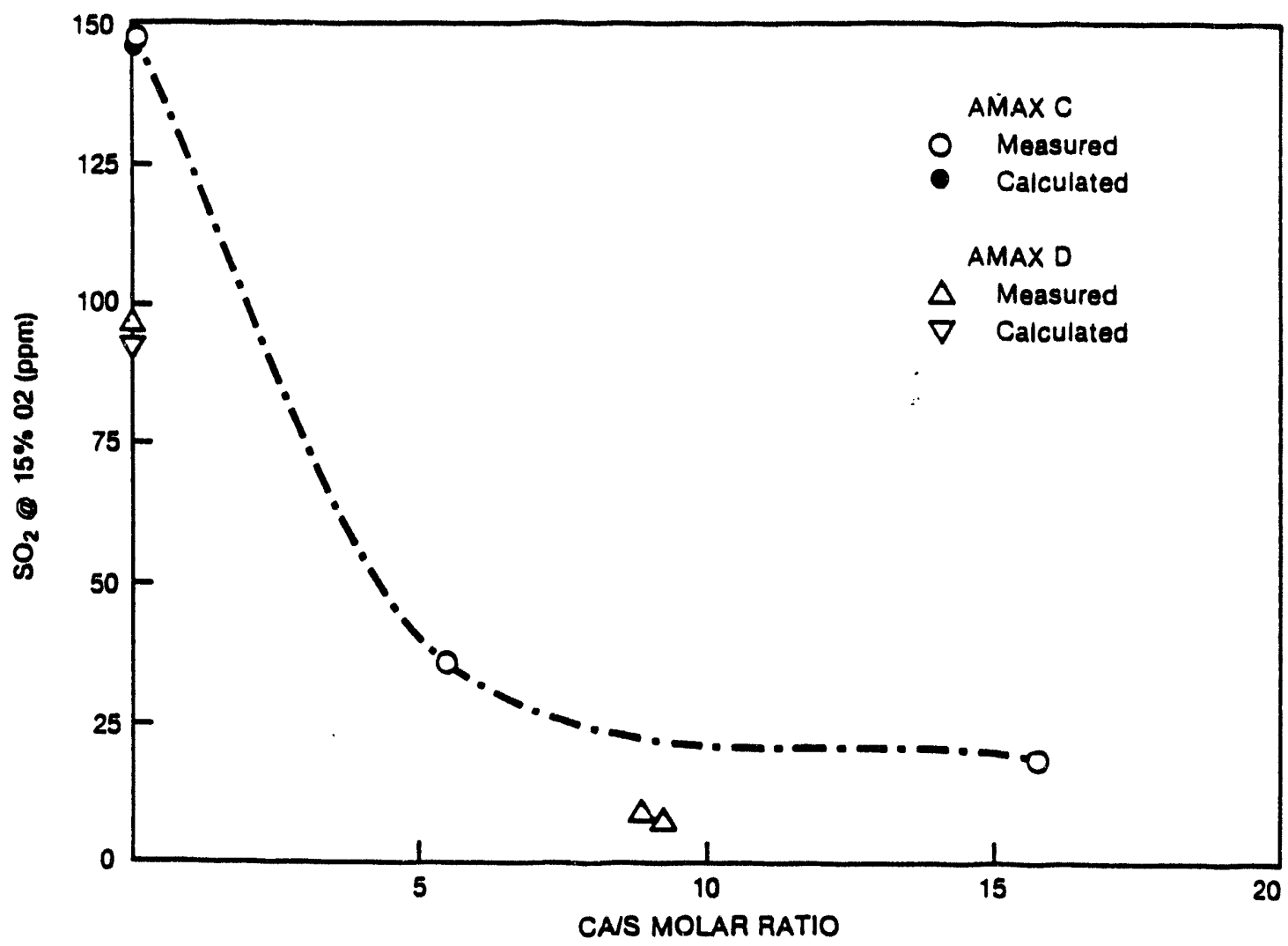

Flgure 16. Actual Measured $\mathrm{SO}_{2}$ Levels at Varying Dolomite Injection Rates Compared to Theoretical $\mathrm{SO}_{2}$ Levels Based on Fuel Sulfur Content With No Sorbent Injection

it was a frozen slag droplet and its image supports this interpretation. Difficulty in analyzing the particulate for sulfur species results from the water-quench sampling technique which tends to put the sulfur in solution removing most sulfur from the particulate. A sample gathered without water dilution was necessary to validate some of these conclusions.

In order to resume sorbent evaluation testing two steps had to have been taken to obtain $\mathrm{SO}_{2}$ reduction data at $\mathrm{Ca} / \mathrm{S}$ ratios less than 5 . First a CWM made from a coal with a sulfur concentration of $1.4 \mathrm{wt} \%$ was ordered. By doubling the coal sulfur concentration the required sorbent feed rates were increased. To maintain a Ca/S ratio of 3 the feed rate was increased from 39 to $73 \mathrm{pph}$, a flow rate which was demonstrated by the dense phase pneumatic feed system.

The second step to obtain data was construction of an auger-type screw feeder, as illustrated in Figure 20. The screw feeder was designed, manufactured, and delivered. Shakedown tests to determine sorbent flow rate as a function of auger speed have been completed. Figure 21 shows the relation of sorbent flow rate with auger speed and dial setting. As is evident both of these are linearly related to sorbent flow rate at atmospheric pressure. The sorbent flow rate was also measured through the weight difference of the sorbent tank over a known time interval. The agreement of measuring sorbent flow rate by tank weight difference and dial setting (collected sorbent weight) was within $2 \%$. The auger continues to demonstrate a linear relation between dial setting and feedrate at combustor pressures as determined by comparing flow rates measured by tank weight difference and dial settings. The linear relation holds true up to a flow rate of $100 \mathrm{pph}$. 
Table 6. Particulate Analysie of Sample Collected in Test No. 500 With Dolomite Injectlon

\begin{tabular}{|c|c|c|}
\hline Fuel: & \multicolumn{2}{|c|}{ AMAX 'C' } \\
\hline $\begin{array}{l}\text { Dolomite: } \\
\text { Ca/s }\end{array}$ & \multicolumn{2}{|c|}{$\begin{array}{l}\text { National Minerals Dolowhite \#100 Select } \\
5.5\end{array}$} \\
\hline \multicolumn{2}{|c|}{$\begin{array}{l}\text { Particulate (wrt\%) } \\
\text { Carton } \\
\text { Sulfur } \\
\text { Ash and Dolomite } \\
\text { Ash } \\
\text { Spent Sorbent } \\
\end{array}$} & $\begin{array}{r}39.2 \\
0.62 \\
60.18 \\
40.09 \\
59.90\end{array}$ \\
\hline $\begin{array}{c}\text { Ashand } \\
\mathrm{CaO} \\
\mathrm{MgO} \\
\mathrm{SIO}_{2} \\
\mathrm{Al}_{2} \mathrm{O}_{3} \\
\mathrm{Fe}_{2} \mathrm{O}_{3} \\
\mathrm{Na}_{2} \mathrm{O} \\
\mathrm{TO}_{2} \\
\mathrm{~K}_{2} \mathrm{O}^{2} \\
\mathrm{MnO}_{2} \\
\end{array}$ & imite & $\begin{array}{r}45.9 \\
27.1 \\
14.75 \\
4.25 \\
4.12 \\
1.64 \\
0.30 \\
0.25 \\
0.11 \\
\end{array}$ \\
\hline $\begin{array}{l}\text { Dllution- } \\
\mathrm{SO}_{4} \\
\mathrm{Ca} \\
\mathrm{Cl} \\
\mathrm{Na} \\
\mathrm{K} \\
\mathrm{SI} \\
\mathrm{LI}\end{array}$ & $r(0 p m$ & $\begin{array}{r}620.0 \\
191.3 \\
124.0 \\
114.0 \\
7.2 \\
3.3 \\
0.1\end{array}$ \\
\hline
\end{tabular}




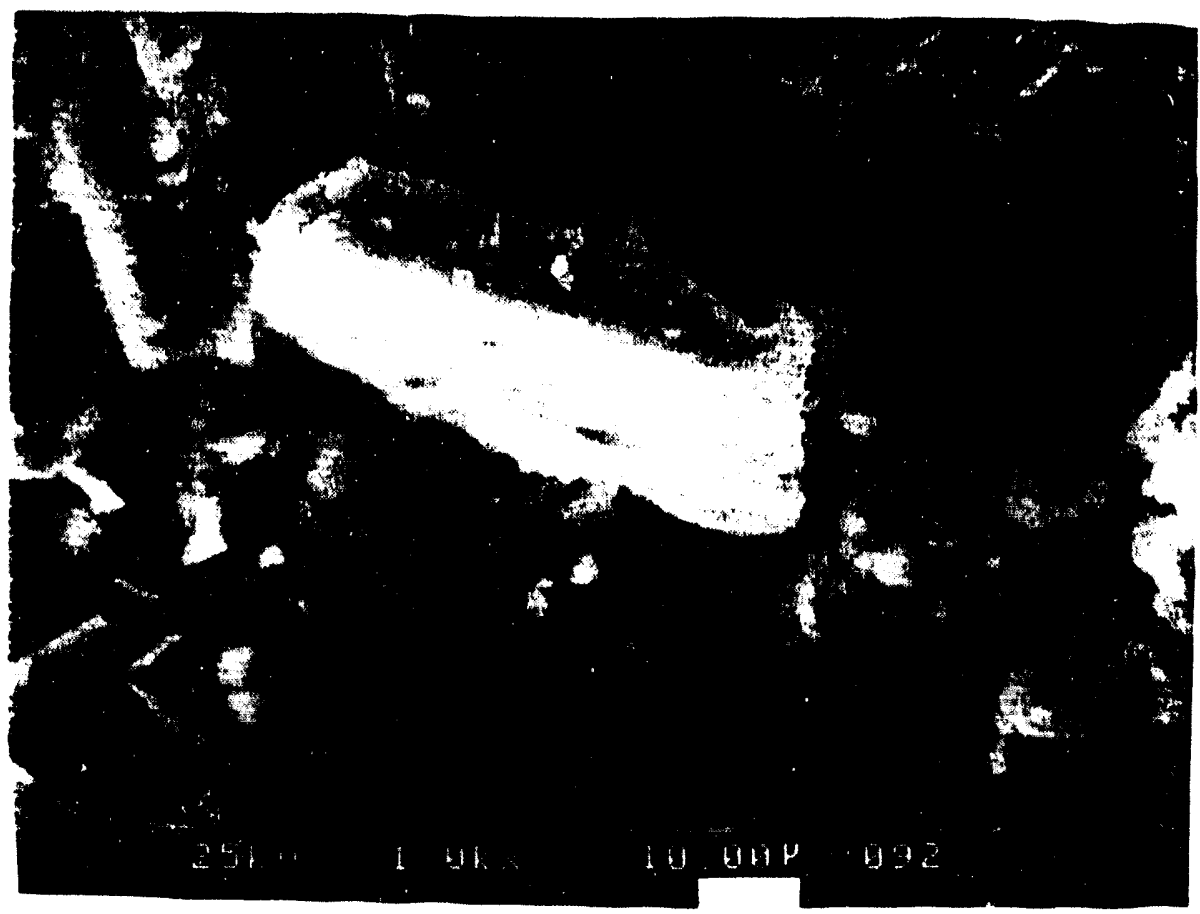

(A) Before Injection

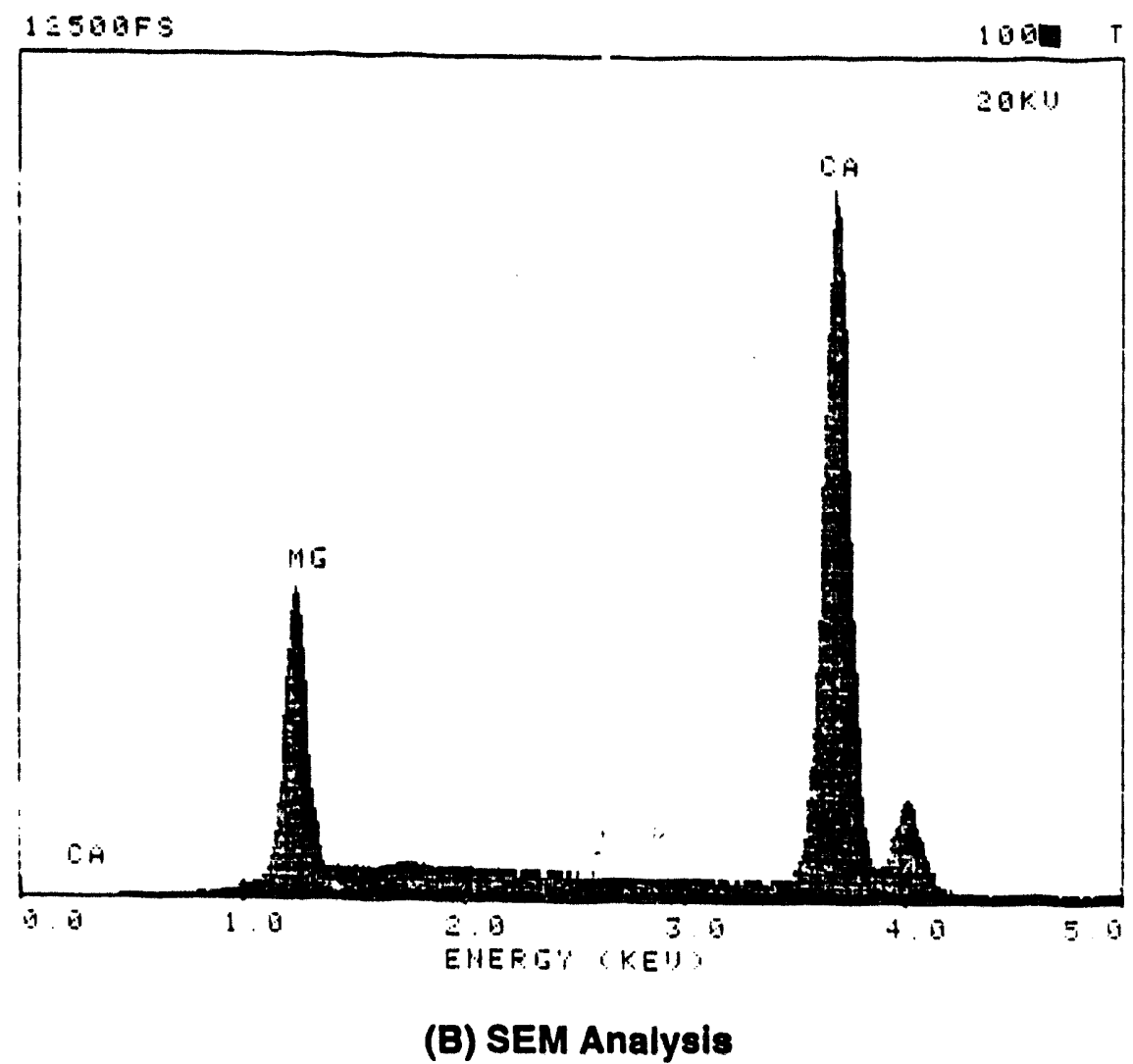

Figure 17. Raw Powdered Dolomite 


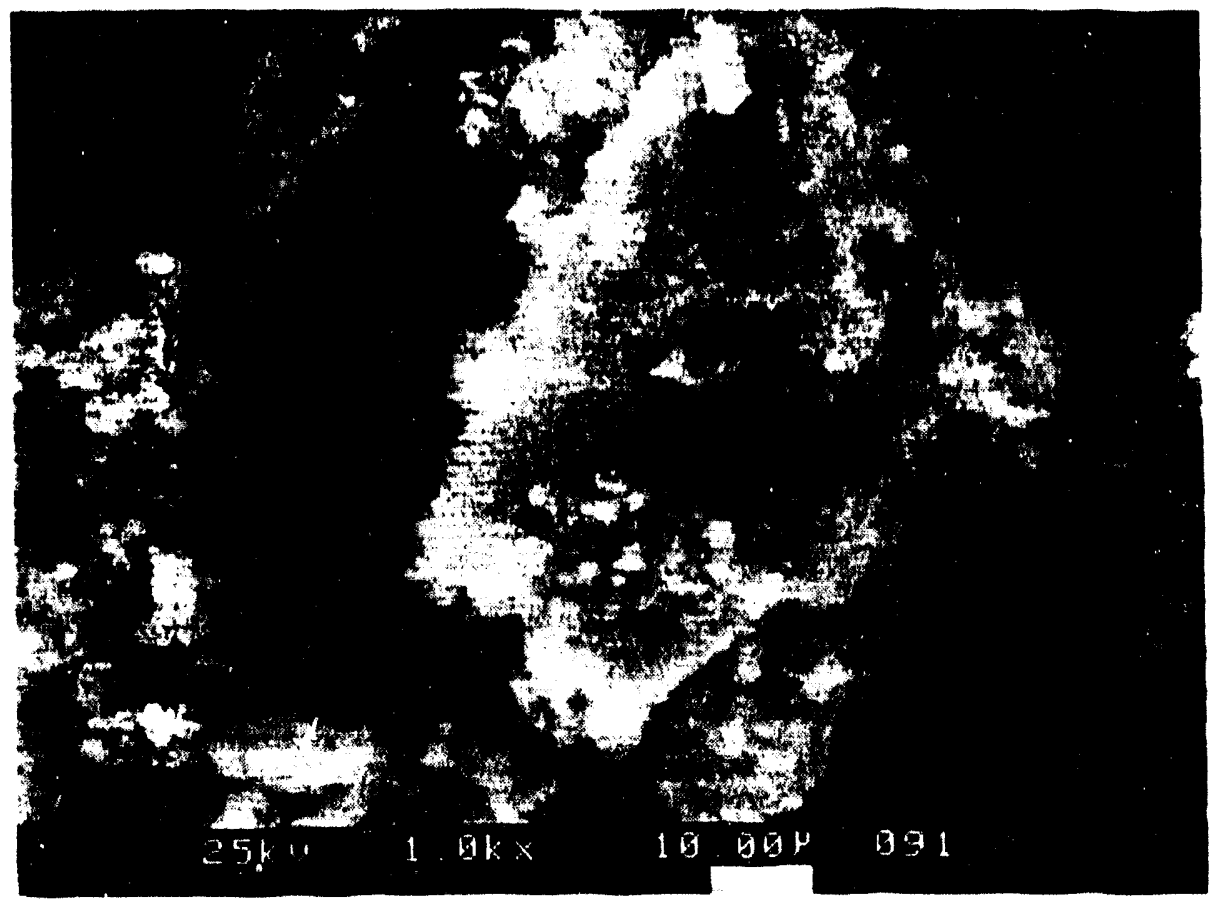

(A) SorbentAsh Particulate
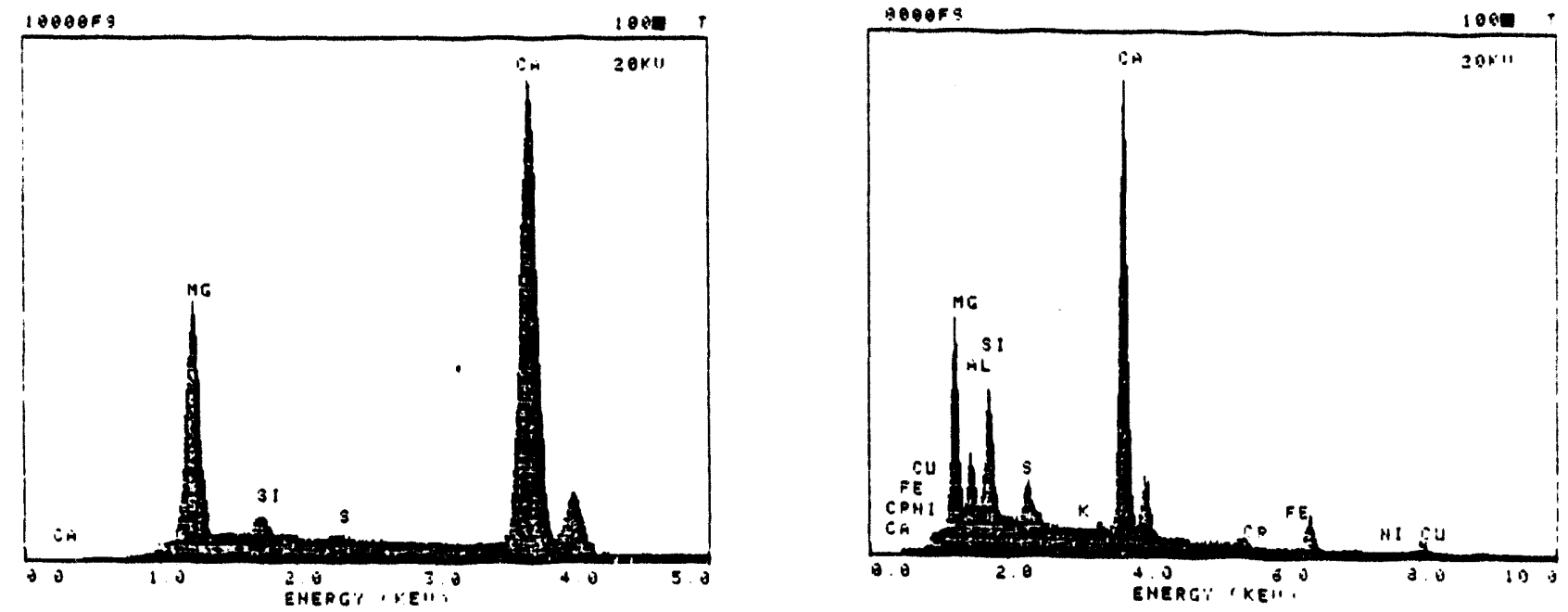

(B) SEM Analyals of Smaller Nodules Located on Particles

(C) SEM Analysis of Larger Particle Surface of Sample

Figure 18. SorbentAsh Particulate Collected in Test No. 5 


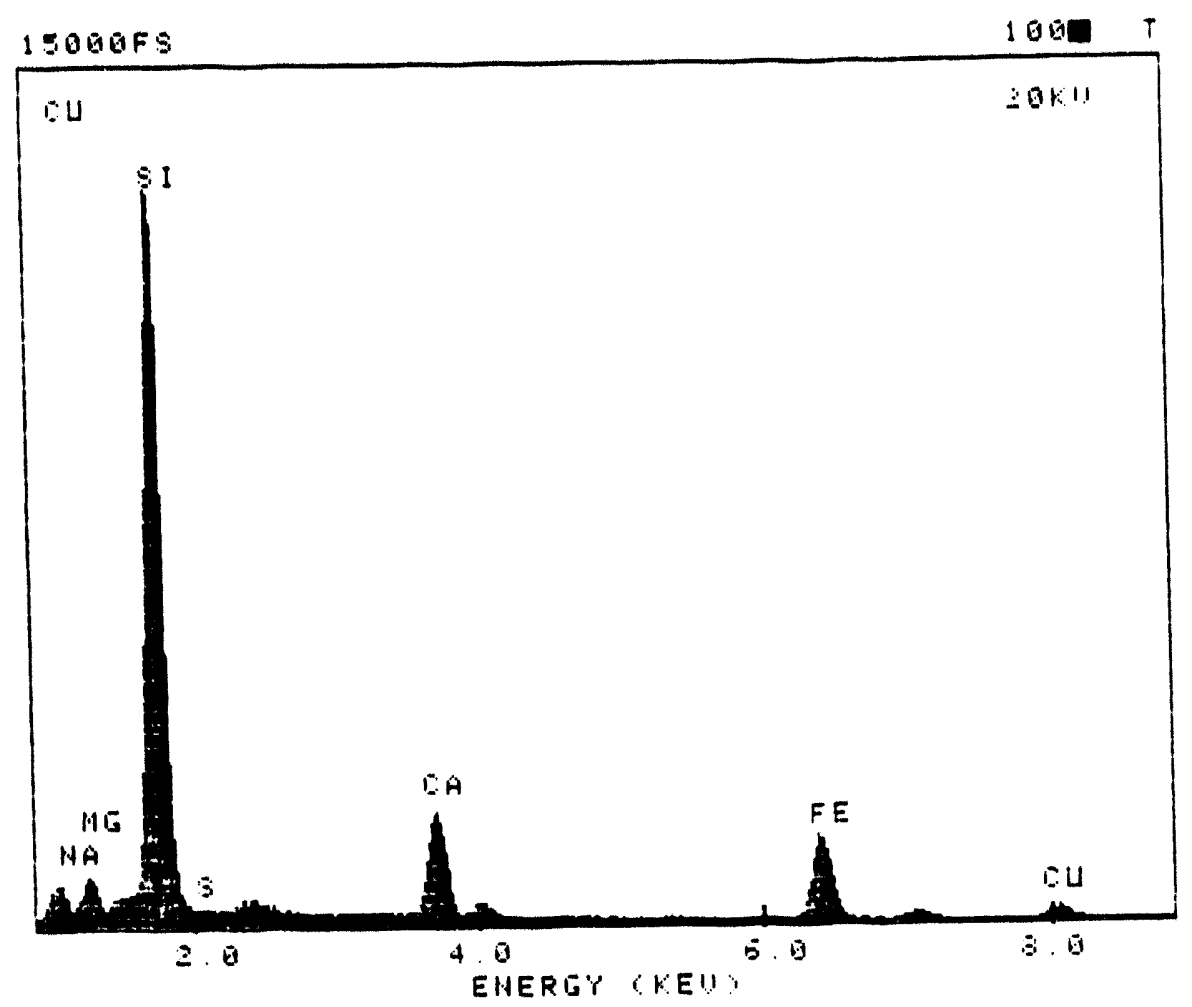

Figure 19. SEM Analysis of "Glassy" Spheriod In Particle Sample
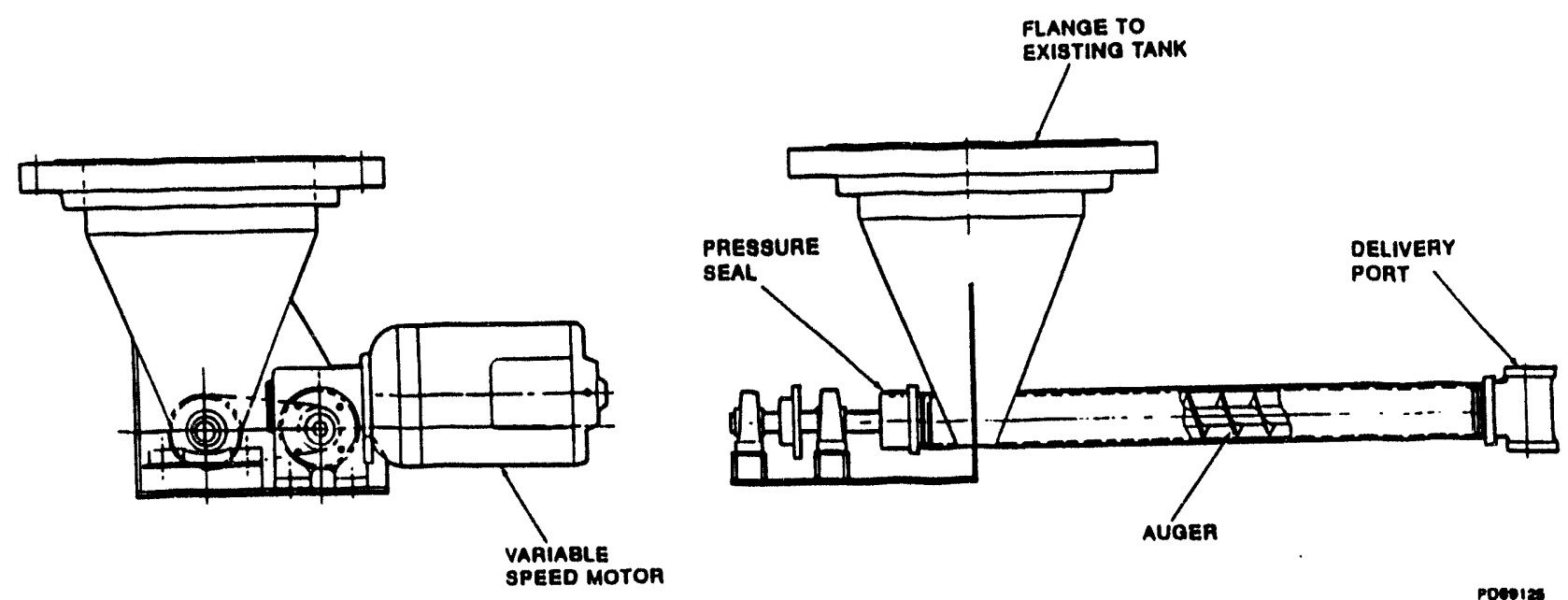

Figure 20. Sorbent Screw Feeder 


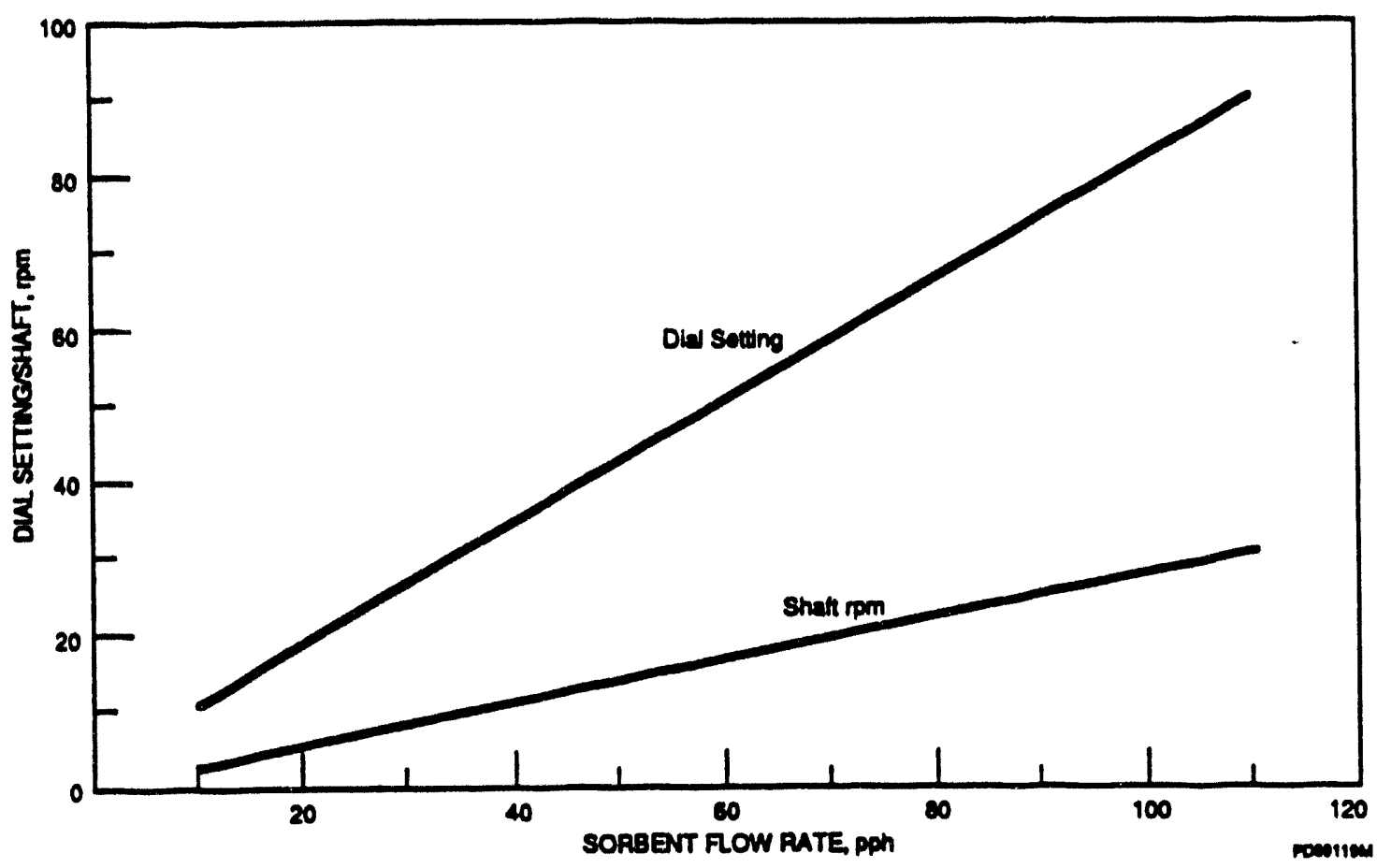

Figure 21. Sorbent Screw Feeder Atmospheric Calibration

The TSSC was run to evaluate dolomite, pressure hydrated dolomitic lime (PHDL, $\mathrm{Ca}(\mathrm{OH})_{2} \mathrm{Mg}(\mathrm{OH})_{2}$ ), and hydrated lime $\left(\mathrm{HL}, \mathrm{Ca}(\mathrm{OH})_{2}\right)$. The sulfur capture of both PHDL and $\mathrm{HL}$ was superior to dolomite with $\mathrm{HL}$ slightly better than $\mathrm{PHDL}$ HL has demonstrated $\mathrm{SO}_{2}$ reductions as high as 90 at $\mathrm{Ca} / \mathrm{S}$ ratio of 3.0 buming CWM ' $\mathrm{O}$ ' (1.4 wt\% S). The difference between sorbent effectiveness of HL and PHDL was only slight and selection of one of these sorbents was appropriate from a sulfur removal standpoint. It should be remembered that other factors such as cost, and the ability for the secondary filter to handle each sorbent must be considered when rating the sorbent types. The sorbent test plan still calls for evaluation of limestone ground with the CWM and delivered in the primary zone.

The properties of all the sorbents are included in Tables 7 and 8 . These analyses were provided by the supplier and AMAX R\&D, respectively. As is evident from the tables all three sorbents are composed primarily of calcium and magnesium compounds with ash concentrations for dolomite, PHDL, and HL of $0.67 \%, 0.60 \%$ and $0.60 \%$, respectively. Dolomite has a much higher bulk density and a slightly higher true density than the other sorbents. The sieve analysis indicates that $\mathrm{HL}$, PHDL, and dolomite, respectively, have slightly increasing particulate size. The median particle sizes shown in Table 8 confirm this characterization. Also shown in Table 8 is the specific surface area and porosity of all three sorbents. As indicated dolomite has a much lower surface area and is less porous than the other two sorbents. All three are commercially available sorbents typical of those expected to be used in the CFC. 
Table 7. Chemical and Physical Analyses of Calclum-Based Sorbents Used in Recent Teats

\begin{tabular}{|c|c|c|c|}
\hline $\begin{array}{l}\text { Suppller } \\
\text { Brand Name }\end{array}$ & $\begin{array}{c}\text { National Minerals } \\
\text { Dolomite } \# 100\end{array}$ & $\begin{array}{l}\text { Chemstar Type } S \\
\text { Hydrlded Llime }\end{array}$ & $\begin{array}{l}\quad \text { Hl. } \\
\text { Chematar } \\
\text { Hlgh Calclum } \\
\text { Hydrated Limo }\end{array}$ \\
\hline $\begin{array}{l}\text { Bulk } \\
\text { Density (Ibs/tt3) } \\
\text { Specific gravity } \\
\text { Cost (\$/ton) }\end{array}$ & $\begin{array}{l}50 \\
2.86 \\
20.00\end{array}$ & $\begin{array}{r}25 \\
2.24 \\
119.00\end{array}$ & $\begin{array}{c}86 \\
2.23 \\
119.00\end{array}$ \\
\hline \multicolumn{4}{|l|}{ Chemical Analysis } \\
\hline Acid Insoluble & - & 0.40 & 1.5 \\
\hline $\begin{array}{l}\mathrm{Fe}_{2} \mathrm{O}_{3} \\
\mathrm{SiO}_{2} \\
\mathrm{Al}_{2} \mathrm{O}_{3} \\
\mathrm{MgCO}_{3} \\
\mathrm{CaCO}_{3} \\
\mathrm{CaO} \\
\mathrm{MgO} \\
\mathrm{Mg}(\mathrm{OH})_{2} \\
\mathrm{Ca}(\mathrm{OH})_{2} \\
\mathrm{H}_{2} \mathrm{O} \\
\text { ASTM Lime \% Available }\end{array}$ & $\begin{array}{l}0.12 \\
0.47 \\
0.08 \\
42.57 \\
57.20 \\
- \\
- \\
- \\
- \\
0.1\end{array}$ & $\begin{array}{l}0.10 \\
-- \\
0.50 \\
-\overline{1.50} \\
0 . \\
0.60 \\
40.00 \\
55.00 \\
0.4 \\
-\end{array}$ & $\begin{array}{c}0.10 \\
\overline{0} \\
\overline{0.50} \\
\overline{1.50} \\
\text { Trace } \\
1.00 \\
\overline{95.00} \\
0.50\end{array}$ \\
\hline \multicolumn{4}{|l|}{$\frac{\text { Sieve Analysis }}{\text { (\% Less) (microns) }}$} \\
\hline $\begin{array}{l}297 \\
149 \\
105 \\
74 \\
44 \\
30 \\
20 \\
10 \\
5 \\
2 \\
1\end{array}$ & $\begin{array}{l}99.3 \\
90.0 \\
76.0 \\
57.0 \\
40 \\
35.0 \\
27.0 \\
15.0 \\
9.0 \\
3.0 \\
7.0\end{array}$ & $\begin{array}{l}99.0 \\
96.0 \\
90.0 \\
86.0 \\
79.0 \\
= \\
= \\
= \\
= \\
=\end{array}$ & $\begin{array}{r}100 \\
100 \\
99 \\
97 \\
88 \\
= \\
= \\
= \\
= \\
-\end{array}$ \\
\hline Surface Area $\left(M^{2} / g m\right)$ & -. & $25-30$ & $20-30$ \\
\hline
\end{tabular}


Table 8. Analyses of Calcium-Based Sortents

\begin{tabular}{|c|c|c|c|}
\hline Suppller Brand Name & $\begin{array}{c}\text { HL } \\
\text { Chemstar } \\
\text { High Calcium } \\
\text { Hydrided Lime }\end{array}$ & $\begin{array}{c}\text { PHDL } \\
\text { ChemStar } \\
\text { Type S } \\
\text { Hydrated Lime }\end{array}$ & $\begin{array}{l}\text { Dolomite } \\
\text { National Minerals } \\
\text { Dolomite \#100 }\end{array}$ \\
\hline Loss on Ignition Weight \% & 24.2 & 26.9 & 46.2 \\
\hline $\mathrm{CO}_{2}$, Weight $\%$ & 0.62 & 0.95 & 44.3 \\
\hline $\mathrm{SO}_{3}$, Weight $\%$ & 0.007 & 0.005 & 0.042 \\
\hline Hydration $\mathrm{H}_{2} \mathrm{O}$ (Diff.) Weight \% & 23.6 & 25.9 & 1.9 \\
\hline $\begin{array}{l}\text { Dry Sieve, Weight \% } \\
-150 \mu \mathrm{m} \\
-75 \mu \mathrm{m} \\
-45 \mu \mathrm{m}\end{array}$ & $\begin{array}{l}99.1 \\
97.3 \\
92.7\end{array}$ & $\begin{array}{l}88.1^{(1)} \\
27.1^{(1)} \\
15.2^{(1)}\end{array}$ & $\begin{array}{l}87.4^{(2)} \\
65.7^{(2)} \\
53.1^{(2)}\end{array}$ \\
\hline Specific Surface, $\mathrm{m}^{2} / \mathrm{g}$ & 18.7 & 20.1 & 0.51 \\
\hline $\begin{array}{l}\text { Mercury Porosimetry } \\
\text { Particle Density } \\
\text { Bulk Density } \\
\text { Internal Porosity, co/g }\end{array}$ & $\begin{array}{l}1.88 \\
1.49 \\
0.61\end{array}$ & $\begin{array}{l}1.98 \\
1.52 \\
0.65\end{array}$ & $\begin{array}{l}2.64 \\
0.62 \\
\text { small(3) }^{(3)}\end{array}$ \\
\hline $\begin{array}{l}\text { Miedian Pore Size }(\mu \mathrm{m}) \\
\text { ( } 50 \% \text { relative pore volume) }\end{array}$ & 0.58 & 0.22 & $4.5^{(4)}$ \\
\hline
\end{tabular}

Listed in Table 9 are the test conditions and combustor performance results of test Nos. 30, 31, and 32 in which the three sorbents were evaluated. Test conditions were typical of previous testing to evaluate other aspects of combustor performance with air inlet temperatures of $620^{\circ} \mathrm{F}$ and combustor pressure of $80 \mathrm{psig}$. Outlet temperatures are maintained between $1730^{\circ}$ and $1790^{\circ} \mathrm{F}$ in all testing. Tests were conducted in the baseline combustor with conical primary zone walls. The fuel injectors have modified air/assist and fuel tip assemblies that have shown in atomization studies to produce CWM droplets of SMD 30 microns. The test fuel was CWM ' $O$ ' which has the same characteristics of all recent test fuels ( $54 \%$ coal, 45 micron top-size, $300 \mathrm{cp} \mathrm{viscosity,} \mathrm{and} 4 \%$ ash) with the exception of a sulfur wt\% of 1.4. At a primary zone equivalence ratio of 1.3, this CWM could generate a maximum $\mathrm{SO}_{2}$ concentration in the exhaust of $280 \mathrm{ppmvd} \odot 15 \% \mathrm{O}_{2}$. 
Table 9. Result of Combustor Performance with Three Sorbents Injected into Secondary Zone

\begin{tabular}{|c|c|c|c|}
\hline & \multicolumn{3}{|c|}{ Sorbent Injected } \\
\hline & Dolomite & PHDL (1) & $H_{L}{ }^{(2)}$ \\
\hline Test No. & 29 & 31 & 32 \\
\hline 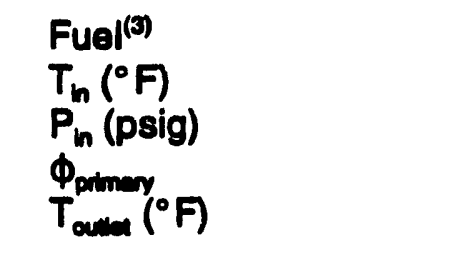 & $\begin{array}{l}' O ' \\
616 \\
75 \\
1.19 \\
1731\end{array}$ & $\begin{array}{l}'{ }^{\prime} \\
628 \\
74.9 \\
1.27 \\
1738\end{array}$ & $\begin{array}{l}' 0 ' \\
637 \\
73.6 \\
1.42 \\
1786\end{array}$ \\
\hline Besults & & & \\
\hline $\begin{array}{l}\text { Emissions } \odot 15 \% \mathrm{O}_{2} \\
\mathrm{NO}_{\mathrm{x}} \mathrm{ppmv} \\
(\mathrm{lbm} / \mathrm{MMBtu})\end{array}$ & $\begin{array}{l}117 \\
(0.9738)\end{array}$ & $\begin{array}{l}92.3 \\
(0.3735)\end{array}$ & $\begin{array}{l}78.9 \\
(0.3145)\end{array}$ \\
\hline $\begin{array}{l}\text { CO ppmv } \\
\text { (lbm/MMBtu) } \\
\text { (no sorbent) }\end{array}$ & $\begin{array}{l}9.19 \\
(0.0226)\end{array}$ & $\begin{array}{l}7.34 \\
(0.0179)\end{array}$ & $\begin{array}{l}15.88 \\
(0.323)\end{array}$ \\
\hline Carbon Conversion \% & 99.8 & 98.9 & 97.6 \\
\hline $\begin{array}{l}\text { Sorbent Injection } \\
\text { Range (pph) } \\
\text { (Ca/S) }\end{array}$ & $\begin{array}{l}24-145 \\
(0.94-5.7)\end{array}$ & $\begin{array}{l}6-46 \\
(0.55-4.10)\end{array}$ & $\begin{array}{l}14-36 \\
(1.15-2.91)\end{array}$ \\
\hline $\begin{array}{l}\mathrm{SO}_{2} \text { Reductions (\%) } \\
\odot \mathrm{Ca} / \mathrm{S} \text { of } 3.0\end{array}$ & 55 & 82 & 90 \\
\hline $\mathrm{Ca} / \mathrm{S} \odot \mathrm{SO}_{2}-75 \mathrm{ppmv}$ & 3.4 & 2.4 & 1.5 \\
\hline
\end{tabular}

Pollutant emissions shown in Table 9 are characteristic of tests with the conical primary walls and modified injector. $\mathrm{NO}_{\mathrm{x}}$ emissions are well below goal of $125 \mathrm{ppmvd}$ and $\mathrm{CO}$ emissions are well below $50 \mathrm{ppmvd}$ with the standard relation with equivalence ratio shown. The carbon conversion is seen to vary from 97.6 to $99.8 \%$ dependent on the equivalence ratio with a value of $99 \%$ close to design setting.

Sorbent results are summarized in Table 9 and included in greater detail in Figures 22, 23, and 24. Figure 22 indicates the $\mathrm{SO}_{2}$ emissions reductions resulting from dolomite injection as a function of molar $\mathrm{Ca} / \mathrm{S}$ ratio. $\mathrm{SO}_{2}$ reductions are calculated as the measured $\mathrm{SO}_{2}$ with sorbent injection that quantity divided by the measured $\mathrm{SO}_{2}$ without sorbent injection. $\mathrm{All}^{\mathrm{SO}_{2}}$ emissions samples are 


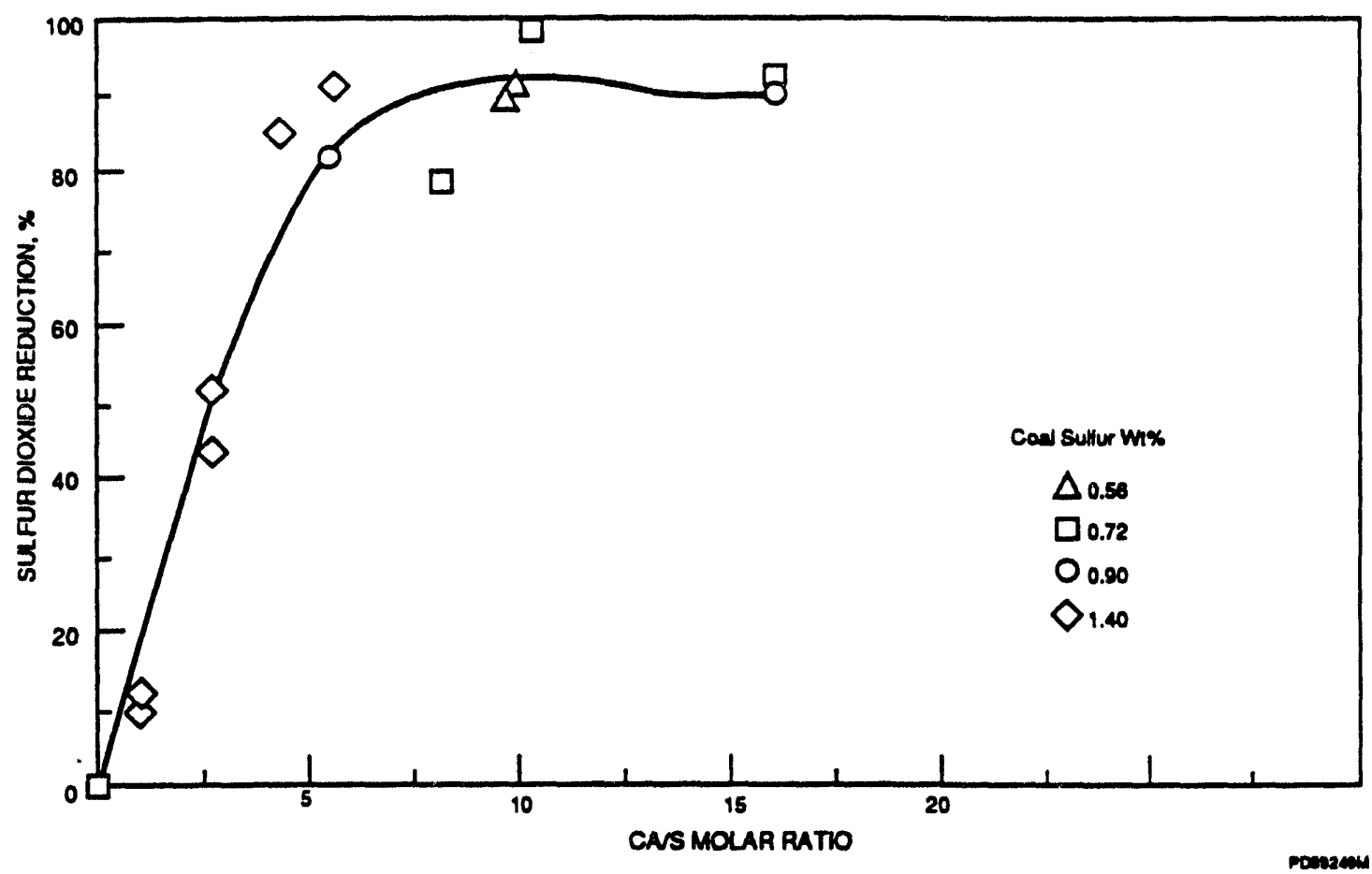

Figure 22. $\mathrm{SO}_{2}$ Emission Reductions for Dolomite Injection in the Secondary Zone

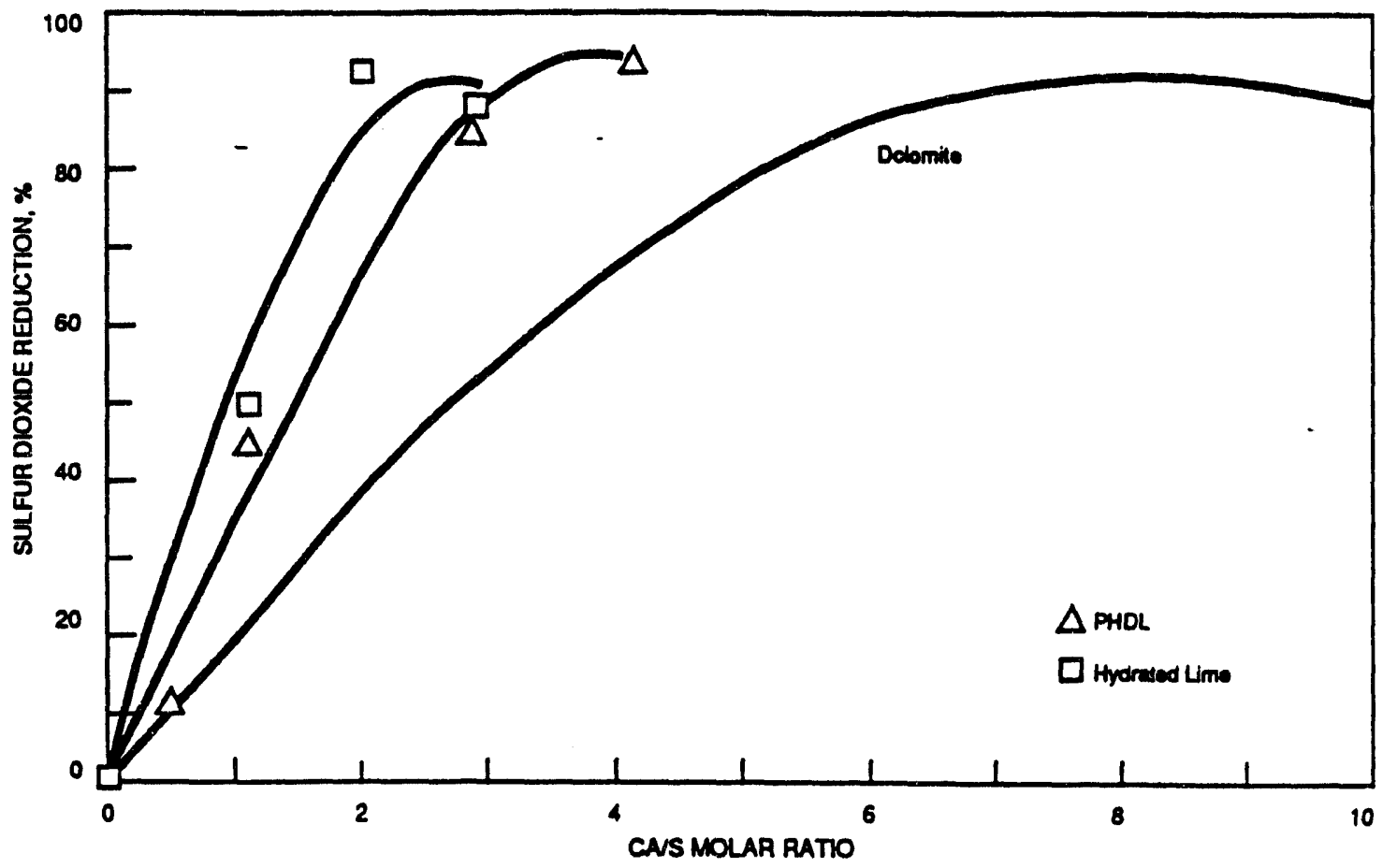

Figure 23. Comparison of $\mathrm{SO}_{2}$ Reduction for Three Calclum Sorbents Injected Into the Secondary Zone of the TSSC Burning a CWM with 1.4 wt\% Sulfur 


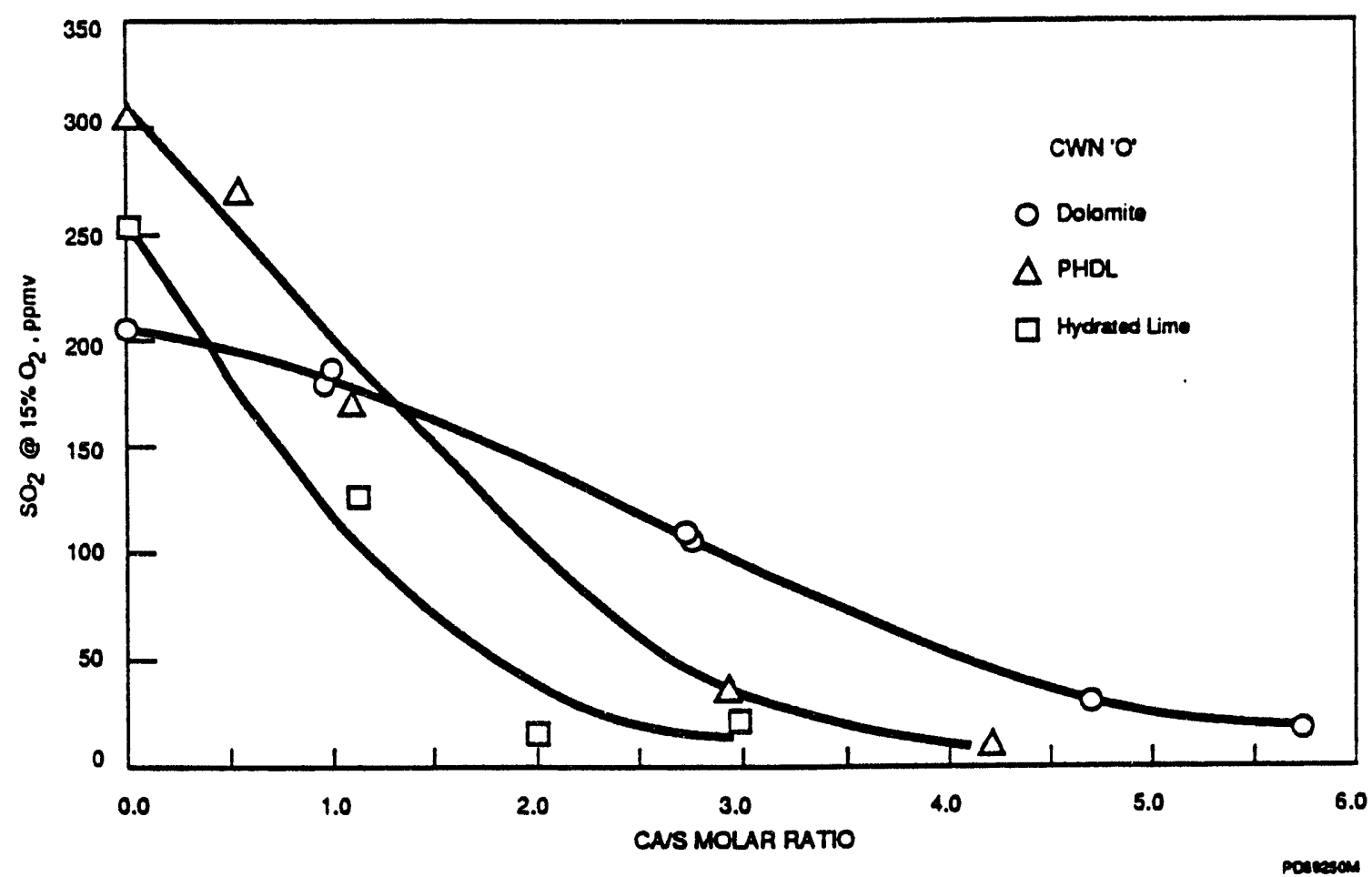

Figure 24. Comparison of $\mathrm{SO}_{2}$ With Varying Injection Rates of Three Sorbents into the Secondary Zone of the TSSC

drawn continuously from the outlet of the residence time test section, which was a refractory lined pipe mounted on top of the secondary zone providing an additional $150 \mathrm{~ms}$ of exhaust gas residence time at $1850^{\circ} \mathrm{F}$ before water quench addition. Sulfur dioxide concentraitons are measured with a Westem Research UV SO $\mathrm{S}_{2}$ Gas Anlyzser. Measured $\mathrm{SO}_{2}$ emissions are compared with theoretical $\mathrm{SO}_{2}$ emisions assuming all the sulfur in the CWM was converted to $\mathrm{SO}_{2}$ at the exhaust. Typically the theroetically-calculated $\mathrm{SO}_{2}$ levels are 10 to $15 \%$ higher than the measured $\mathrm{SO}_{2}$ emissions without sorbent injection.

In Figure 23 the same dolomite curve is shown with $\mathrm{SO}_{2}$ emissions reduction data taken injecting PHDL and HL into the secondary zone. As summarized in Table 9 at a $\mathrm{Ca} / \mathrm{S}$ ratio of 3 , which was the design sorbent loading, reductions of 55,82 , and $90 \%$ are achieved with dolomite, PHDL, and $H L$, respectively. The sorbent injection ranges listed in Table 9 are the required mass flows to vary the $\mathrm{Ca} / \mathrm{s}$ ratios over an anticipated operation range. The $\mathrm{Ca} / \mathrm{S}$ ranges are also listed. The measured exhaust $\mathrm{SO}_{2}$ concentrations for these tests are included in Figure 24. As shown in Figure 24, $\mathrm{SO}_{2}$ concentration drops off fastest with $\mathrm{Ca} / \mathrm{S}$ ratio while injecting $\mathrm{HL}$. It should be remembered as indicated in Table 7 that the particulate size of the three sorbents vary as noted with dolomite being the largest grind and hydrated lime the smallest grind. This trend suggests that the sulfur capture results of the three sorbents may also be partially attributed to particle size. No effort was made to separate the two factors that vary in this study of sorbent particle size and chemical composition at the present time. The sorbent samples were selected from commercial sources because they represent the stock that would be used in the CFC. However, in view of the results, the independent influence of particle size and sorbent chemistry on sulfur capture requires further study. To achieve Solar's design $\mathrm{SO}_{2}$ emissions goal of 75 ppmvd while burning CWM 'O'; HL, PHDL, and dolomite must be injected at $\mathrm{Ca} / \mathrm{S}$ ratios of $1.5,2.4$, and 3.4 , respectively. 
The performance of dolomite relative to PHDL and HL was anticipated and had been documented in past work. The performance difference between PHDL and HL was only slightly above measurement error, but does indicate that HL was superior. Richard Newby of Westinghouse R\&D consulting to Solar accurately assessed the relative effectiveness of these three sorbents in the TSSC including the slight improve-ment of HL over PHDL. The costs of dolomite, PHDL, and HL are shown in Table 7. The table indicates that HL and PHDL have comparable costs while dolomite is about one-sixth of the others. PHDL was the least favorable candidate sorbent for use in the CFC based on the cost, sorbent effectiveness, and material handling. Dolomite was favored for sorbent injection based on cost and material handling, but for high sulfur CWM's would require quantities well in excess of $\mathrm{Ca} / \mathrm{S}$ of 3 . The effectiveness of dolomite should improve with the secondary filter installed due to the added residence time it will provide. A final sorbent selection can not be made until tests are conducted with the secondary filter. Tests are still planned to inject limestone mixed with the CWM into the primary zone.

The sorbent evaluation test plan was completed with several more subscale tests in the TSSC. The test set-up and procedure was described in detail in LeCren et.al., 1989 and Cowell et.al., 1990. Recent work has focused on sulfur capture with high sulfur CWM, with sorbent mixed with the slurry, and sorbent injection of finer grinds. Test conditions and results are summarized in Table 1 under TSSC Test Nos. 34, 35, 36, and 42.

Two tests (Nos. 34 and 35 ) have been run using CWM ' $F$ ' as the fuel. The properties of CWM ' $F$ ' and ' $G$ ' are shown in the Appendix. Both $C W M$ ' $F$ ' and ' $G$ ' are made from the same source coal which contains a higher sulfur loading ( 3.13 versus $1.0 \mathrm{wt} \%$ sulfur) than was used in most testing. The principle difference between CWM ' $F$ ' and ' $G$ ' is that ' $G$ ' was made with pressure hydrated dolomitic lime (PHDL) ground with the coal during CWM preparation. Several other properties that differ substantially between ' $F$ ' and ' $G$ ' are the coal content, ash content, and carbon content. The purpose of testing with CWM 'F was two-fold: first, to establish a set of $\mathrm{SO}_{2}$ baseline data without any sorbent addition including collecting and analyzing slag samples; and secondly, to evaluate dolomite for sulfur capture at higher $\mathrm{SO}_{2}$ concentrations.

The data taken while buming CWM ' $F$ ' is graphically summarized in Figures 25 and 26 . Figure 25 shows the $\mathrm{SO}_{2}$ reductions at varying $\mathrm{Ca} / \mathrm{S}$ ratios for dolomite injection buming $\mathrm{CWM}$ ' $\mathrm{F}$ ' and other CWMs (sulfur loadings of 0.56 to 1.44 wt\%). Sulfur dioxide reduction was calculated as the measured $\mathrm{SO}_{2}$ without sorbent injection minus the measured $\mathrm{SO}_{2}$ without sorbent injection. This data indicates that a slight increase in sorbent effectiveness was realized as coal sulfur loading was increased. The result had been predicted by Newby (Westinghouse R\&D consulting to Solar) and others. The effect wasn't noticeable as the coal sulfur level was varied from 0.56 to $1.44 \mathrm{wt} \%$ because the experimental error was relatively large compared to the improved gains in sulfur capture. Absolute $\mathrm{SO}_{2}$ concentrations are included in Figure 26 and coincide with the data presented in Figure 20. In summary the dolomite effectiveness at a $\mathrm{Ca} / \mathrm{S}$ ratio of 3.0 was $63 \%$ reduction in the $\mathrm{SO}_{2}$ level. This reduction still leaves an $\mathrm{SO}_{2}$ concentration of $200 \mathrm{ppmv}$ which was well above the $75 \mathrm{ppmv}$ goal of the CFC. In order to reduce $\mathrm{SO}_{2}$ concentrations to $75 \mathrm{ppmv}$ injecting dolomite at a Ca/S ratio of 5.5 to 6.5 (extrapolating from Figure 26) would be required.

One test (Nos. 36) was performed using CWM 'G' as the fuel. The purpose of testing with CWM 'G' was to evaluate the sulfur capture effectiveness of grinding a sorbent with the coal during slurry preparation and injecting the slurry in the primary zone as a sorbent-coal fuel. By combining the CWM and sorbent delivery a substantial savings to the system cost could be realized. 


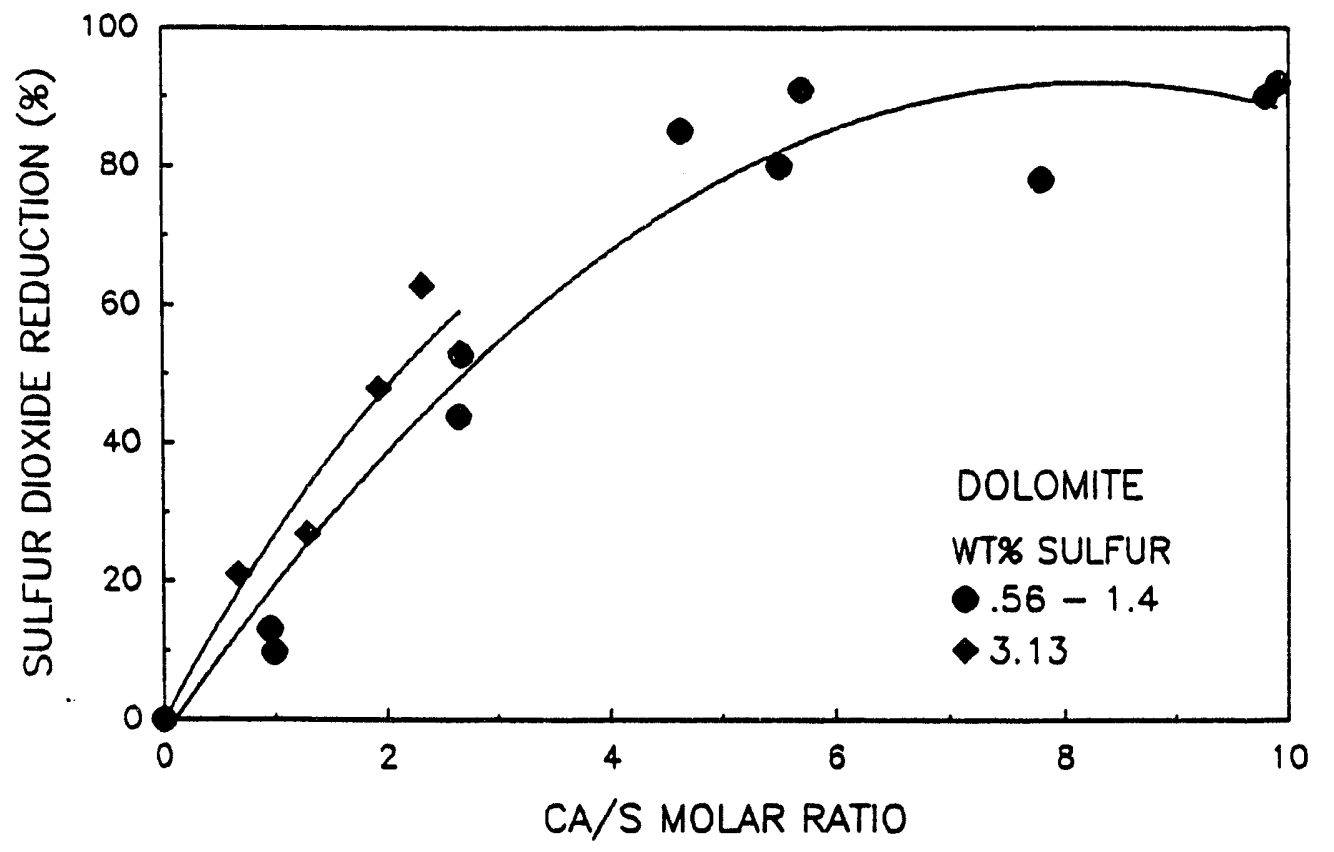

Figure 25. $\mathrm{SO}_{2}$ Reduction of Dolomite Injected In the Secondary Zone of the TSSC Burning CWMs of Varying Sulfur Loading

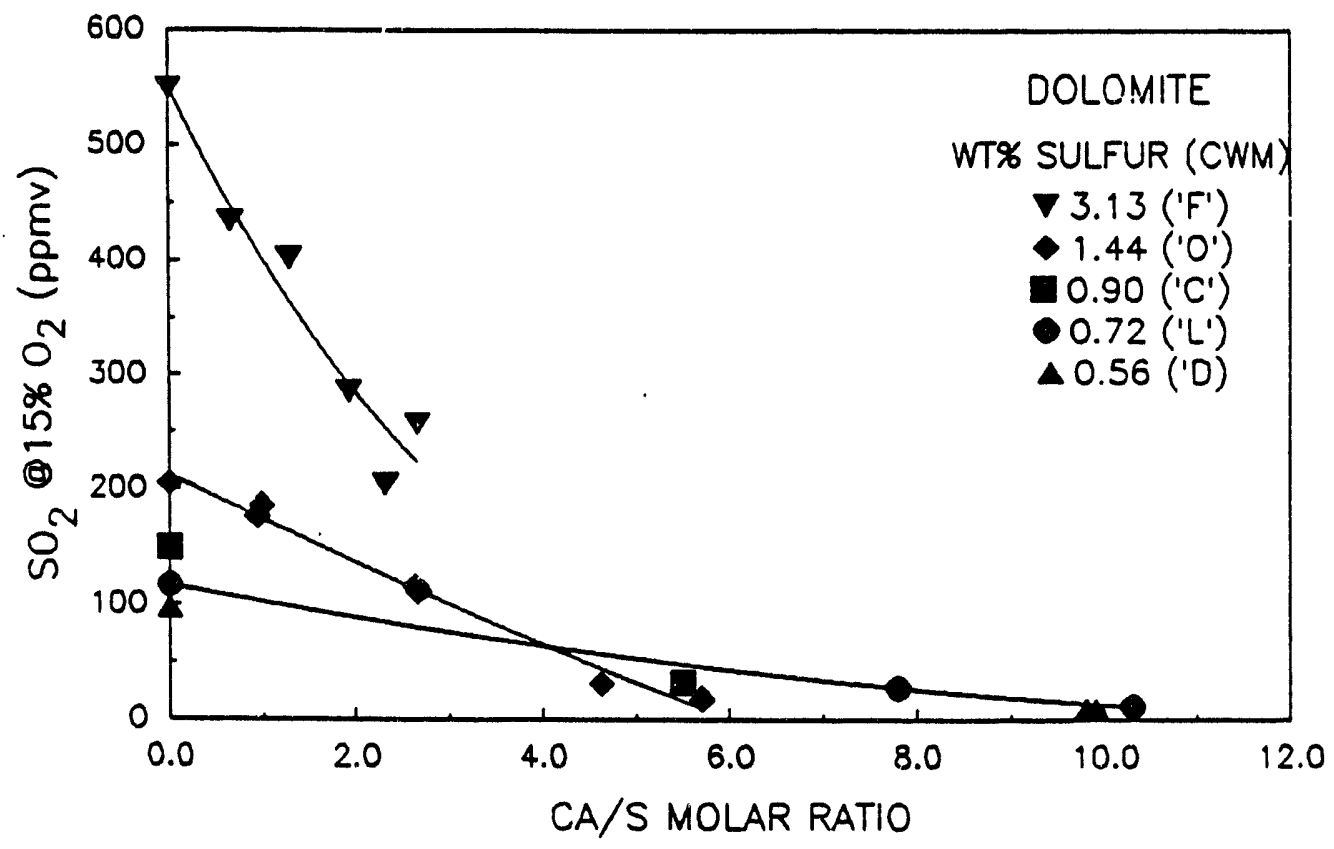

Figure 26. $\mathrm{SO}_{2}$ Emissions at Varying Ca/S Ratios of Dolomite Injection 
In TSSC No. 36 the $\mathrm{SO}_{2}$ emissions are not noticeably lowered by the sorbent mixed in with the fuel. Comparing the $\mathrm{SO}_{2}$ emissions measured without sorbent injection from Test No. 35 (658 ppmv) with these results from Test No. 36 (648.7 ppmv), the $\mathrm{SO}_{2}$ reduction was less than $2 \%$. The reduction based on theoretical emissions was $12.8 \%$. These reductions do not compare favorably to earlier results taken injecting sorbents into the secondary combustion zone. Analysis of slag collected from the slag pit indicates that only $0.4 \%$ of the coal sulfur was removed with the slag. This result supports that sulfur capture by the calcia in the primary zone was poor. Another serious consequence of mixing the sorbent with the CWM was that calcium reacts with the alumino-silicate refractory walls under reducing conditions to create a eutectic with a lower melting point. During testing severe erosion/melting of the walls took place.

The final area to be investigated was the impact of sorbent grind size on sulfur capture. During TSSC Test No. 42 dolomite of a finer grind was injected into the secondary zone through one of the secondary air inlet lines using the sorbent auger feed system. The dolomite was procured from National Minerals as were previously tested samples. The only difference between this supply and past supplies was the dolomite mesh. Past batches of dolomite were a 50 mesh size which corresponds to an approximate 300 micron top-size. This batch was 325 mesh with a corresponding top-size of $\mathbf{4 5}$ microns. Properties of these dolomites are included in Table 10.

The results of testing with this sorbent compared to dolomite tested previously with a larger particulate size are shown graphically in Figure 27. In this figure, $\mathrm{SO}_{2}$ reduction is plotted against $\mathrm{Ca} / \mathrm{S}$ molar ratio for both grinds of dolomite. The finer grind of dolomite improves the sulfur capture as expected. The degree of improvement was less than anticipated. Richard Newby of Westinghouse R\&D while consulting for Solar predicted that approximately halving the dolomite particle size should double the sulfur reductions. In this test work reducing the particle top size from 300 to 45 microns has led to only a $30 \%$ improvement in $\mathrm{SO}_{2}$ reductions. The results suggest that using finely ground dolomite offers only a slight advantage over coarse grinds in terms of $\mathrm{SO}_{2}$ reductions.

In summary, recent testing evaluating sorbents for sulfur capture have indicated that a slight improvement in sorbent sulfur removal efficiency was realized with increased sulfur loading of the CWM. Sorbent ground with CWM and injected into the primary combustion zone as a fuelsorbent does not demonstrate high $\mathrm{SO}_{2}$ reductions. Particle size of the sorbent does have a strong influence on sulfur capture, however not as strong an influence as predicted by others.

\subsection{FUEL PROPERTY SPECIFICATION TESTING}

As a means of assessing the flexibility of the TSSC design on using a wide range of CWM fuels a series of tests were completed with fuels formulated with a range of properties. The purpose of the testing was to determine the limits for the fuel specification needed for the Coal-Fueled Centaur. The fuel properties that were varied include the coal loading, the ash concentration, the particle size, fuel additives, and bituminous coals from several regional seams. The fuel tests were completed in the TSSC configuration with the water quench slag removal system as illustrated in Figure 28.

A listing of all the fuels used and their properties are included in Table 11. The tests completed with these fuels and the important results are summarized in Table 12. 
Table 10. Properties of Dolomite of Different Grinds

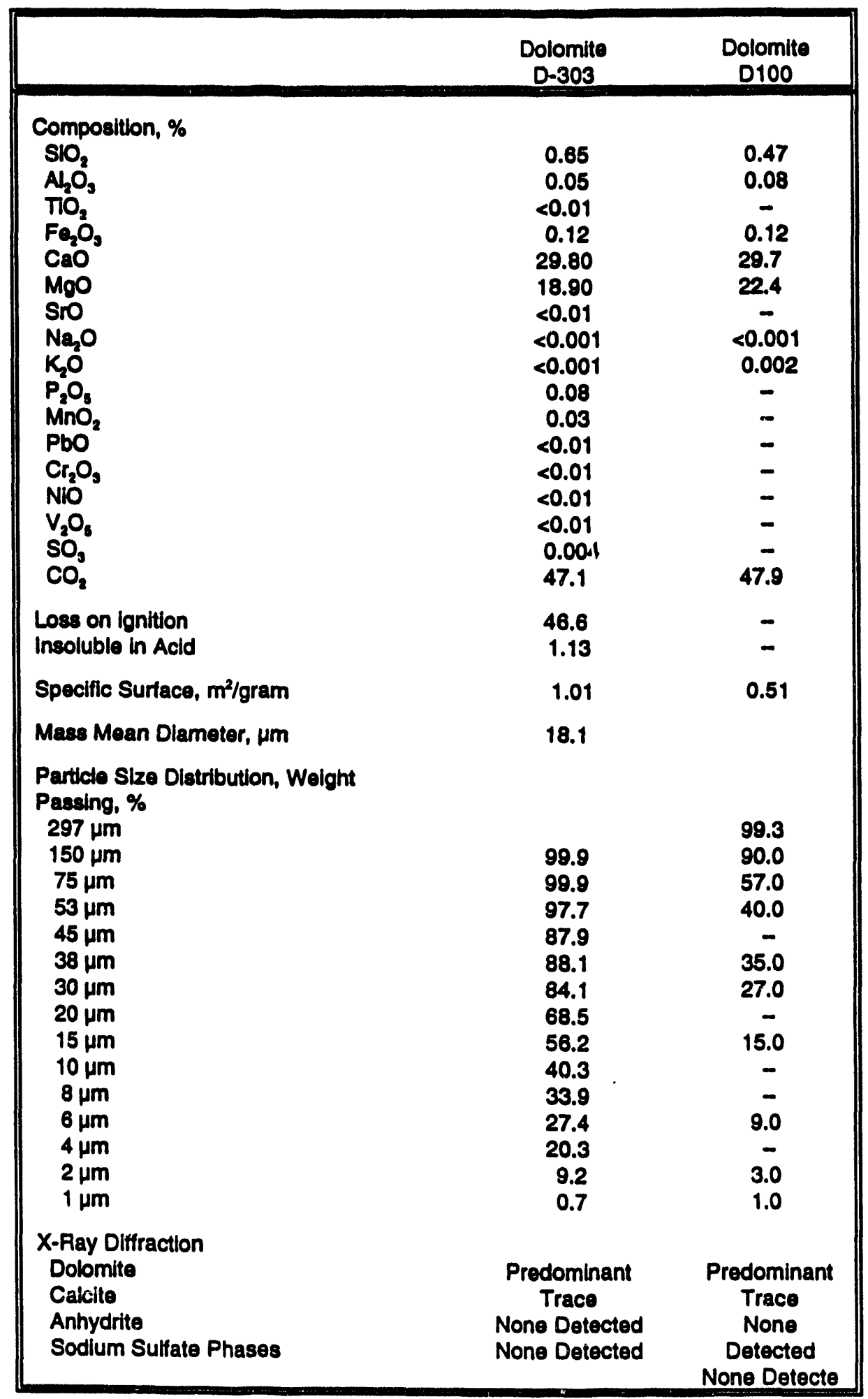




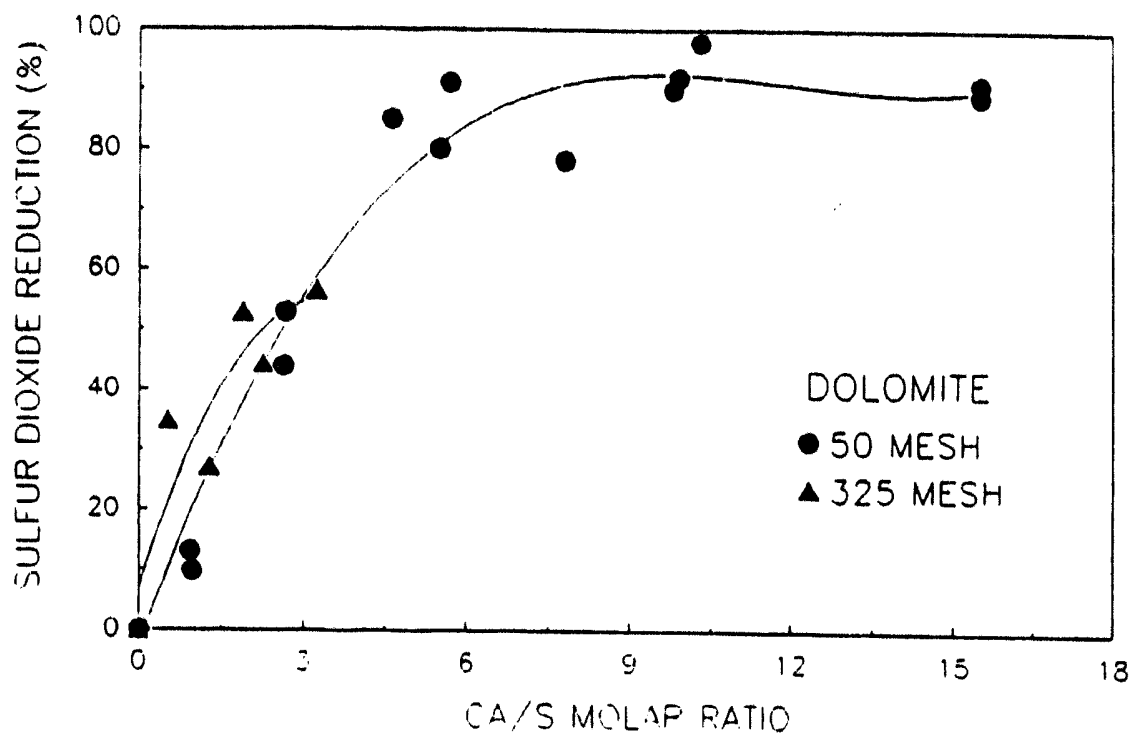

Figure 27. Comparison of $\mathrm{SO}_{2}$ Reductions of Dolomite of Varying SIzes Injectod Into the Secondary Zone

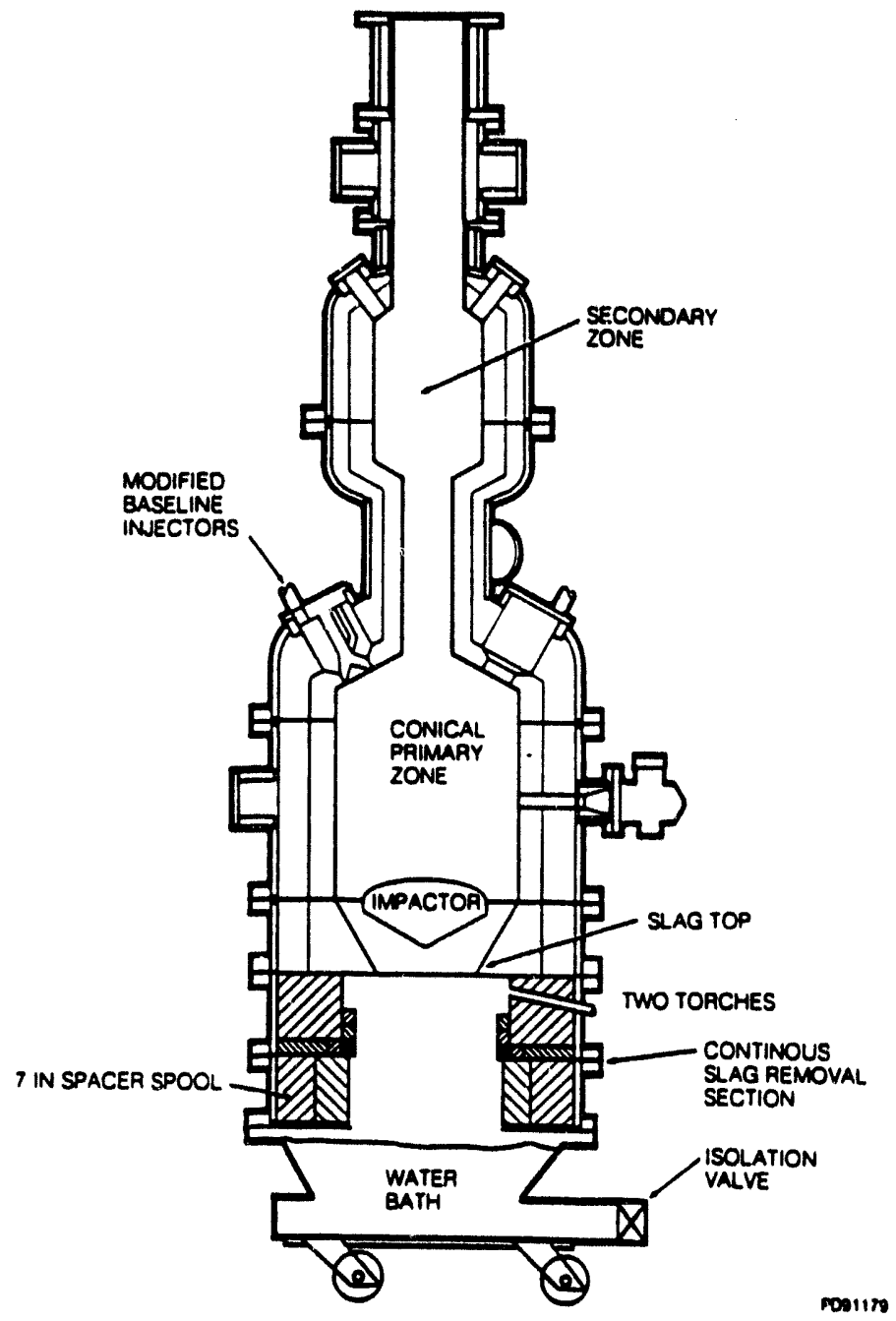

Figure 28. TSSC Test Configuration for Evaluation of Fuels of Varying Propertles 
Table 11. Properties and Compositions of Combustion Testing Fuels

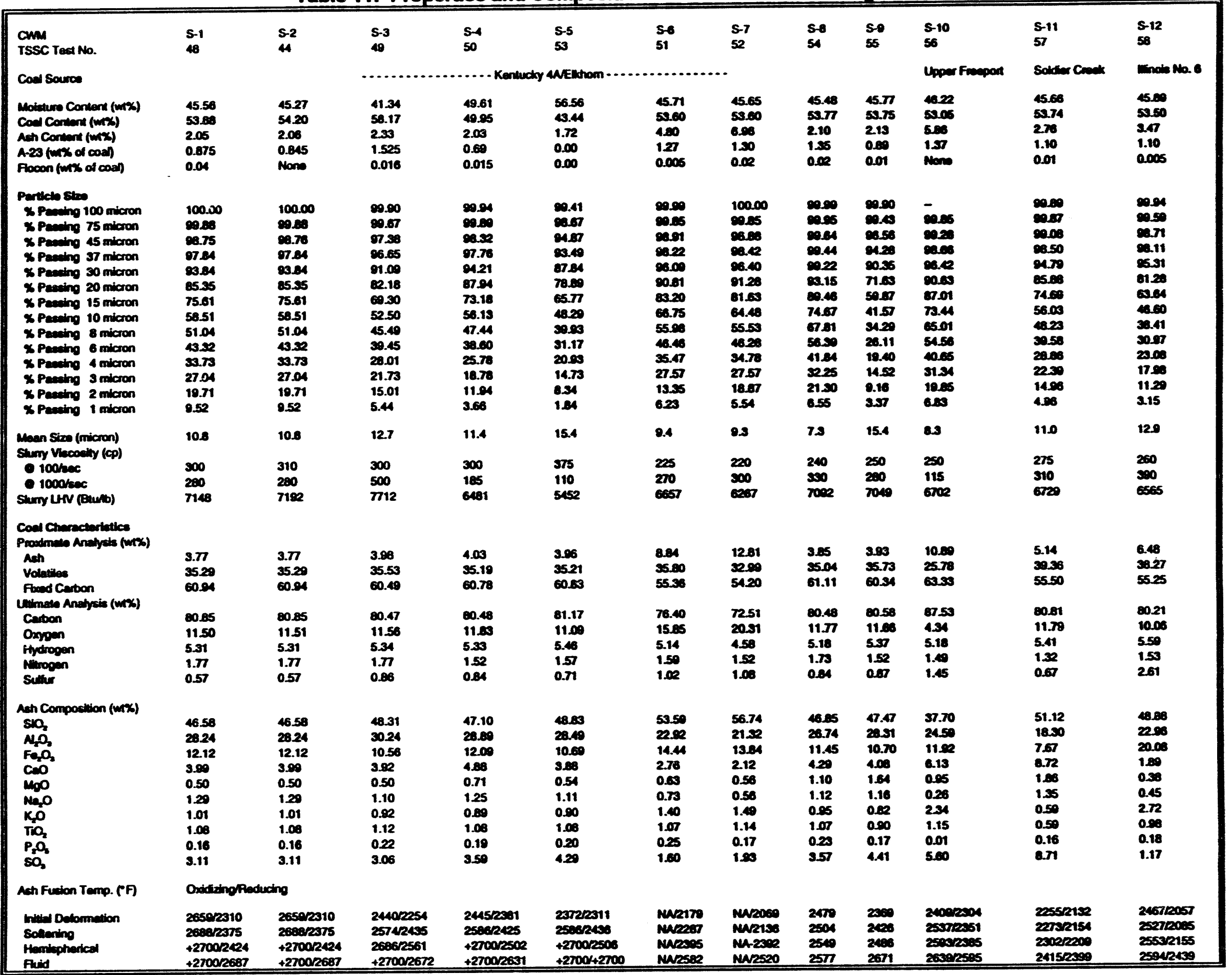


Table 12. Summary of CWM Testing of Fuele of Varying Properties

\begin{tabular}{|c|c|c|c|c|c|}
\hline Test No. & 48 & 49 & 50 & 51 & 52 \\
\hline $\begin{array}{l}\text { CWM } \\
\text { (critical property) }\end{array}$ & $" S 1 "$ & $\begin{array}{c}\text { "S3" } \\
\text { (High Coal Load) }\end{array}$ & $\begin{array}{c}\text { "S4" } \\
\text { (Low Coal Load) }\end{array}$ & $\begin{array}{c}\text { "S6" } \\
\text { (mod. ash) }\end{array}$ & $\begin{array}{c}\text { "S7" } \\
\text { (high ash) }\end{array}$ \\
\hline$T_{n}(\bullet F)$ & 653 & 652 & 625 & 626 & 639 \\
\hline$P_{n}$ (psig) & 79.5 & 78.4 & 75.7 & 76.7 & 76.0 \\
\hline$\phi_{\text {monney }}$ & 1.42 & 1.43 & 1.55 & 1.47 & 1.36 \\
\hline$\Delta P / P(\%)$ & 3.9 & 3.9 & 4.1 & 4.0 & 4.1 \\
\hline $\begin{array}{l}\text { Hoat Input } \\
\text { (MMBtumr) }\end{array}$ & 4.68 & 4.71 & 4.67 & 4.36 & 4.20 \\
\hline$T_{\text {and }}(\bullet F)$ & 1962 & 2107 & 2107 & 1097 & 1968 \\
\hline \multicolumn{6}{|l|}{ BESULTS } \\
\hline \multicolumn{6}{|l|}{ Emiaslons $16 \% \mathrm{O}_{2}$} \\
\hline $\begin{array}{l}\mathrm{NO}_{1} \text { (ppmv) } \\
\text { (1bmMMBtu) }\end{array}$ & $\begin{array}{c}53.3 \\
(0.2225)\end{array}$ & $\begin{array}{c}68.1 \\
(0.3040)\end{array}$ & $\begin{array}{c}86.3 \\
(0.3885)\end{array}$ & $\begin{array}{l}71.70 \\
(0.3080)\end{array}$ & $\begin{array}{c}67.23 \\
(0.2880)\end{array}$ \\
\hline $\begin{array}{l}\text { CO (ppmv) } \\
\text { (lbmMMBtu) }\end{array}$ & $\begin{array}{c}6.1 \\
(0.0155)\end{array}$ & $\begin{array}{c}3.2 \\
(0.0083)\end{array}$ & $\begin{array}{c}7.6 \\
(0.0204)\end{array}$ & $\begin{array}{c}12.9 \\
(0.0344)\end{array}$ & $\begin{array}{c}11.8 \\
(0.0304)\end{array}$ \\
\hline $\begin{array}{l}\mathrm{SO}_{2} \text { (pprmv) } \\
\text { (IbmMMBtu) }\end{array}$ & NA & $\begin{array}{c}178 \\
(1.084)\end{array}$ & $\begin{array}{c}107 \\
(0.6864)\end{array}$ & NA & $\begin{array}{l}257 \\
(1.5323)\end{array}$ \\
\hline Particulate (ppmm) & 2034.1 & 455.2 & 1684.9 & 1167.2 & 750.2 \\
\hline Carbon Conversion (\%) & 97.2 & 99.7 & 97.2 & 99.0 & 99.8 \\
\hline \multicolumn{6}{|l|}{ Ash Balance } \\
\hline $\begin{array}{l}\text { Primary Zone Slag Capture } \\
(\%)\end{array}$ & 37.2 & 23.9 & 28.9 & 28.0 & 46.0 \\
\hline Ash Emitted (\%) & 92.9 & 26.7 & 53.6 & 24.2 & 14.8 \\
\hline $\begin{array}{c}\text { Imbalance (\%) } \\
\text { (lbs) }\end{array}$ & $\begin{array}{l}-30.1 \\
-5.8\end{array}$ & $\begin{array}{l}49.3 \\
10.0\end{array}$ & $\begin{array}{l}17.4 \\
4.63\end{array}$ & $\begin{array}{l}49.3 \\
24.2\end{array}$ & $\begin{array}{l}39.1 \\
39.4\end{array}$ \\
\hline
\end{tabular}


Table 12. Summary of CWM Teating of Fuele of Varying Propertles (Continued)

\begin{tabular}{|c|c|c|c|c|c|c|}
\hline Tost No. & 53 & 54 & 55 & 56 & 57 & 58 \\
\hline $\begin{array}{l}\text { CWM } \\
\text { (critlcal property) }\end{array}$ & $\begin{array}{c}\text { "S5" } \\
\text { (no addltives) }\end{array}$ & $\begin{array}{c}\text { "S8" } \\
\text { (iine grind) }\end{array}$ & $\begin{array}{c}\text { "S9" } \\
\text { (coarse grind) }\end{array}$ & $\begin{array}{l}\text { "S10" } \\
\text { (Upper } \\
\text { Freeport) }\end{array}$ & $\begin{array}{l}\text { "S11" } \\
\text { (Soldier } \\
\text { Creek) }\end{array}$ & $\begin{array}{l}\text { "S12" } \\
\text { (IIIInols } \\
\text { No. 6) }\end{array}$ \\
\hline$T_{n}\left({ }^{\bullet} F\right)$ & 624 & 624 & 628 & 684 & 627 & 618 \\
\hline$P_{n}$ (psig) & 79.9 & 76.1 & 79.7 & 76.0 & 77.0 & 76.0 \\
\hline$\phi_{\text {ptrany }}$ & 1.297 & 1.40 & 1.50 & 1.44 & 1.42 & 1.36 \\
\hline$\Delta P / P(\%)$ & 3.90 & 4.0 & 4.0 & 3.9 & 4.0 & 4.10 \\
\hline $\begin{array}{l}\text { Heat Input } \\
\text { (MMBtu/hr) }\end{array}$ & 4.46 & 5.66 & 4.85 & 4.11 & 4.52 & 4.48 \\
\hline$T_{\text {arat }}\left({ }^{\circ} F\right)$ & 1794 & 2001 & 2038 & 1971 & 2011 & 1970 \\
\hline \multicolumn{7}{|l|}{ BFSULIS } \\
\hline \multicolumn{7}{|l|}{ Emlasions $\odot 15 \% \mathrm{O}_{2}$} \\
\hline $\begin{array}{l}\mathrm{NO}_{\mathrm{z}} \text { (ppmin) } \\
\text { (lbmMMBtu) }\end{array}$ & $\begin{array}{c}81.90 \\
(0.3833)\end{array}$ & $\begin{array}{c}70.16 \\
(0.3100)\end{array}$ & $\begin{array}{c}65.20 \\
(0.2850)\end{array}$ & $\begin{array}{c}55.40 \\
(0.2783)\end{array}$ & $\begin{array}{l}52.00 \\
(0.2350)\end{array}$ & $\begin{array}{c}43.80 \\
(0.2100)\end{array}$ \\
\hline $\begin{array}{l}\text { CO (ppmv) } \\
\text { (lbmMMBtu) }\end{array}$ & $\begin{array}{c}109.7 \\
(0.3127)\end{array}$ & $\begin{array}{c}19.8 \\
(0.0540)\end{array}$ & $\begin{array}{c}11.7 \\
(0.0310)\end{array}$ & $\begin{array}{c}20.9 \\
(0.0637)\end{array}$ & $\begin{array}{c}15.9 \\
(0.0450)\end{array}$ & $\begin{array}{c}23.5 \\
(0.2110)\end{array}$ \\
\hline $\begin{array}{l}\mathrm{SO}_{2} \text { (ppmv) } \\
\text { (1bmMMBtu) }\end{array}$ & $\begin{array}{c}156 \\
(1.0081)\end{array}$ & $\begin{array}{c}156.1 \\
(0.9461)\end{array}$ & $\begin{array}{c}84.7 \\
(0.5250)\end{array}$ & $\begin{array}{c}129.0 \\
(0.9095)\end{array}$ & NA & $\begin{array}{c}40.7 \\
(0.2730)\end{array}$ \\
\hline Particulate (ppmm) & 747.0 & 1038.7 & 872.0 & 169.6 & 235.5 & 1076.1 \\
\hline Carbon Convaraion (\%) & 98.4 & 97.9 & 98.5 & 99.8 & 99.6 & 88.1 \\
\hline \multicolumn{7}{|l|}{ Aah Balance } \\
\hline $\begin{array}{l}\text { Primary Zone Slag } \\
\text { Capture (\%) }\end{array}$ & 22.0 & 21.0 & 18.0 & 31.0 & 23.0 & 54.0 \\
\hline Ash Emitted (\%) & 25.8 & 28.4 & 25.1 & 3.2 & 7.4 & 20.8 \\
\hline $\begin{array}{c}\text { Imbalance (\%) } \\
\text { (lbs) }\end{array}$ & $\begin{array}{c}9.5 \\
52.2\end{array}$ & $\begin{array}{c}51.0 \\
(15.1)\end{array}$ & $\begin{array}{r}57.4 \\
(16.9)\end{array}$ & $\begin{array}{l}65.9 \\
42.8\end{array}$ & $\begin{array}{l}69.2 \\
24.8\end{array}$ & $\begin{array}{c}19.6 \\
9.4\end{array}$ \\
\hline
\end{tabular}


Analyses of particulate samples were completed to provide the carbon conversion and particulate emissions data included in Table 13. This data were taken with the isokinetic sampling prube. The sample was drawn for a four minute period. The sample was quenched with deionized water and separated from the gas stream in a condensation bath with two gas cyclones and filters. The analyses of the samples for the eleven tests are included in Table 13.

\section{Coalunading}

The influence of CWM coal loading has been investigated burning CWM's of loadings of 54.0, 58.2, and $50.0 \%$ in TSSC Test Nos. 48, 49, and 50, respectively. A summary of the CWM properties of these fuels is included in Table 11. The table illustrates that while slight variations in fuel property

Table 13. Particulate Sample Analyses From Tests Completed in TSSC With CWMs of Varying Fuol Properties

\begin{tabular}{|c|c|c|c|c|c|c|c|}
\hline Test No. & 48 & 40 & 50 & 51 & 52 & 53 & 54 \\
\hline CWM & "S1" & "S3" & "S4" & "S6" & $" S 7 "$ & "S5" & "S8" \\
\hline Solids (g) & 19.28 & 4.82 & 15.87 & 11.35 & 7.38 & 8.51 & 58.6 \\
\hline $\begin{array}{l}\text { Carbon (\%) } \\
\text { Ash (\%) }\end{array}$ & $\begin{array}{l}40.5 \\
59.5\end{array}$ & $\begin{array}{l}16.1 \\
83.9\end{array}$ & $\begin{array}{l}51.4 \\
48.6\end{array}$ & $\begin{array}{l}11.35 \\
25.4\end{array}$ & $\begin{array}{l}7.38 \\
6.8\end{array}$ & $\begin{array}{c}8.51 \\
58.3\end{array}$ & $\begin{array}{l}58.6 \\
41.4\end{array}$ \\
\hline Water & 11.8 & 16.0 & 11.9 & 10.7 & 13.6 & 13.4 & 8.1 \\
\hline pH & 2.0 & 2.5 & 2.5 & 2.0 & 2.3 & 2.5 & 2.5 \\
\hline \multicolumn{8}{|c|}{ Ash Analyale (\%) } \\
\hline $\begin{array}{l}\mathrm{Al}_{2} \mathrm{O}_{3} \\
\mathrm{Fe}_{2} \mathrm{O}_{3} \\
\mathrm{SiO}_{2} \\
\mathrm{CaO} \\
\mathrm{K}_{2} \mathrm{O} \\
\mathrm{Na}_{2} \mathrm{O} \\
\mathrm{MO}_{2} \\
\mathrm{MnO}_{2} \\
\mathrm{Cr}_{2} \mathrm{O}_{3} \\
\mathrm{NIO} \\
\mathrm{CuO} \\
\mathrm{MgO} \\
\mathrm{SO} \\
\mathrm{PbO} \\
\mathrm{ZnO}\end{array}$ & $\begin{array}{r}12.63 \\
84.40 \\
15.19 \\
0.13 \\
3.58 \\
1.58 \\
0.73 \\
0.45 \\
0.52 \\
0.18 \\
0.14 \\
0.29 \\
0.10 \\
0.09\end{array}$ & $\begin{array}{r}11.75 \\
68.31 \\
12.04 \\
2.48 \\
1.37 \\
1.08 \\
0.77 \\
0.47 \\
0.45 \\
0.42 \\
0.35 \\
0.27 \\
0.25 \\
0.10 \\
0.10\end{array}$ & $\begin{array}{r}26.63 \\
24.48 \\
34.43 \\
5.78 \\
2.95 \\
1.35 \\
1.80 \\
0.16 \\
0.34 \\
0.28 \\
0.21 \\
0.55 \\
0.04 \\
0.89 \\
0.02\end{array}$ & $\begin{array}{r}27.86 \\
26.64 \\
35.58 \\
0.15 \\
1.85 \\
1.42 \\
1.94 \\
0.09 \\
0.34 \\
0.15 \\
0.07 \\
1.27 \\
0.28 \\
0.08 \\
2.01\end{array}$ & $\begin{array}{r}24.12 \\
17.23 \\
47.75 \\
3.73 \\
1.57 \\
2.34 \\
0.97 \\
0.08 \\
0.28 \\
0.15 \\
0.08 \\
1.02 \\
0.04 \\
0.08 \\
0.09\end{array}$ & $\begin{array}{r}22.47 \\
32.40 \\
36.11 \\
3.33 \\
1.15 \\
1.75 \\
0.62 \\
0.20 \\
0.58 \\
0.17 \\
0.12 \\
0.43 \\
0.17 \\
0.06 \\
0.11\end{array}$ & $\begin{array}{r}28.08 \\
22.90 \\
38.75 \\
0.15 \\
1.90 \\
2.16 \\
2.11 \\
0.11 \\
0.58 \\
0.16 \\
0.08 \\
0.82 \\
0.41 \\
0.07 \\
0.34\end{array}$ \\
\hline \multicolumn{8}{|c|}{ Water Anslysla (ppmm) } \\
\hline $\begin{array}{l}\mathrm{SO} \\
\mathrm{Cu} \\
\mathrm{Fo} \\
\mathrm{Al} \\
\mathrm{SI} \\
\mathrm{Na} \\
\mathrm{Mn} \\
\mathrm{Cr} \\
\mathrm{Ca} \\
\mathrm{Mg} \\
\mathrm{K} \\
\mathrm{NI} \\
\mathrm{Zn} \\
\mathrm{U}\end{array}$ & $\begin{array}{r}437.5 \\
09.43 \\
30.80 \\
9.79 \\
5.29 \\
18.89 \\
2.29 \\
1.58 \\
2.98 \\
3.08 \\
2.81 \\
1.27 \\
0.47 \\
0.02 \\
\end{array}$ & $\begin{array}{r}228.0 \\
7.37 \\
10.70 \\
2.54 \\
2.27 \\
1.31 \\
1.22 \\
0.83 \\
0.68 \\
0.65 \\
0.57 \\
0.35 \\
0.37 \\
0.01\end{array}$ & $\begin{array}{r}620.0 \\
110.5 \\
36.8 \\
13.24 \\
8.64 \\
3.10 \\
1.14 \\
2.96 \\
1.56 \\
1.19 \\
1.85 \\
1.68 \\
0.30 \\
0.03 \\
\end{array}$ & $\begin{array}{r}350.0 \\
4.84 \\
40.00 \\
5.40 \\
3.60 \\
1.75 \\
0.01 \\
7.60 \\
1.07 \\
0.78 \\
1.45 \\
5.90 \\
0.27 \\
0.10 \\
\end{array}$ & $\begin{array}{r}320.0 \\
27.30 \\
16.90 \\
3.68 \\
1.67 \\
0.81 \\
0.66 \\
0.91 \\
0.64 \\
0.34 \\
0.62 \\
0.99 \\
0.11 \\
0.10 \\
\end{array}$ & $\begin{array}{r}240.0 \\
19.90 \\
17.70 \\
7.36 \\
3.33 \\
1.82 \\
0.87 \\
1.14 \\
1.14 \\
0.34 \\
0.60 \\
1.25 \\
0.11 \\
0.01 \\
\end{array}$ & $\begin{array}{c}304.0 \\
35.3 \\
30.20 \\
15.80 \\
7.05 \\
8.70 \\
1.43 \\
1.64 \\
2.01 \\
3.87 \\
1.45 \\
1.07 \\
0.19 \\
0.01\end{array}$ \\
\hline
\end{tabular}


Table 13. Particulate Sample Analyses From Test Completed in TSSC With CWMs of Varying Fuel Properties (Continued)

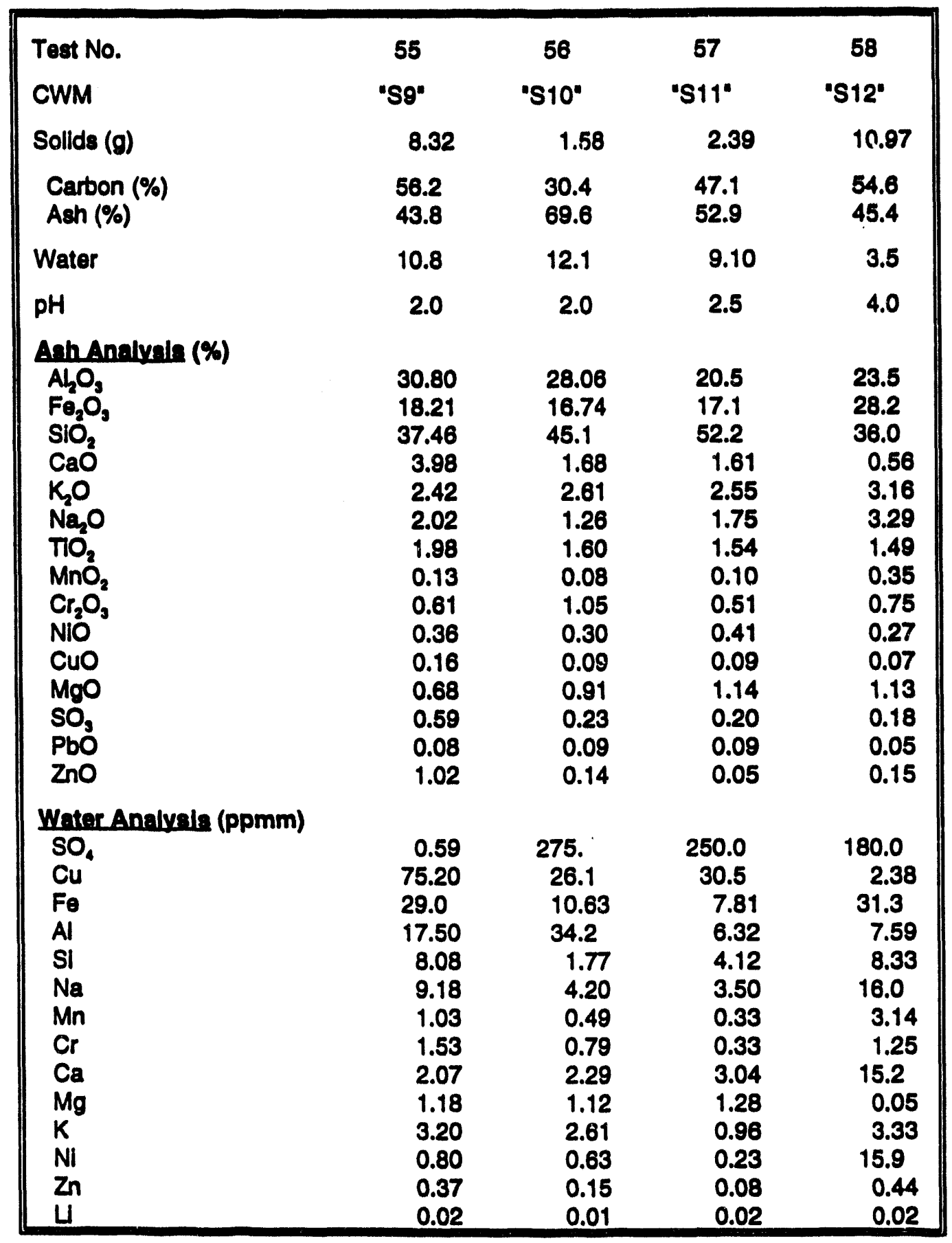


exist the largest variation of the CWM's was in coal loading. Coal loading influences several of the parameters listed in Table 11 in particular, slurry viscosity, slurry LHV, and to a lesser degree CWM ash content. Efforts were made to control viscosity through the addition of stabilizer and dispersant, but for a non-newtonian fluid the viscosity will vary independently of shear rate. The CWM's listed in Table 11 have the same viscosity of $300 \mathrm{cp}$ at $100 \mathrm{sec}^{-1}$, but at $1000 \mathrm{sec}^{-1}$ vary from 185 to $500 \mathrm{cp}$.

The fuel handling properties varied substantially between the CWMs of three different loadings. CWMs "S1" and "S4" were readily pumped through the system and into the combustor. "S3" of higher loading was more difficult to pump resulting in higher pump pressures and larger variations in fuel flow rate. The difficulty in pumping each fuel appears to be proportional to the viscosity at $1000 \mathrm{sec}^{-1}$. While fuels of loadings in excess of $58 \%$ could be efficiently utilized in the combustor a refinement to the pumping system would be required.

The combustor exhibited good operation with all three fuels. The combustion tests were operated at nearly identical conditions as listed in Table 12. The largest variation in test conditions was in primary zone equivalence ratio. The tests were to be operated at an equivalence ratio of 1.38. The values listed in Table 12 are all higher, particularly in Test No. 50. The discrepancy stems from the additional fuel input through the slag tap torches and the inefficiency in combustion as reflected in carbon conversion. Typically, the airfuel ratio was tracked and controlled during testing through the measured air and fuel inputs. The primary equivalence ratio was then calculated based on the measured $\mathrm{O}_{2}$ concentration. Often a considerable discrepancy can exist between these two for the reasons sighted above.

The outlet temperature was dependent on the primary equivalence ratio and the coal loading of the fuel. This relation is illustrated in Figure 29. Graphed is outlet temperature versus equivalence ratio for the fuels with the three loadings. A trend of increasing coal loading producing increasing outlet temperature is shown. It should be noted that the data shown from Test No. 43 was taken while the combustor was operating without the slag tap heating torches. The remaining data was taken at a constant slag tap torch heat input. The influence of coal loading on outlet temperature was not large for the data taken with fuels of 50 and $54 \%$ coal loading.

The emissions are summarized in Table 12 and in Figure 30. The values in Table 12 are averaged over the entire test. Emissions of $\mathrm{CO}$ were below $15 \mathrm{ppmv} 15 \% \mathrm{O}_{2}$ for all fuels tested. $\mathrm{SO}_{2}$ emissions are a function of the sulfur loading of the fuel as nearly all the sulfur input into the combustor in the fuel was converted to $\mathrm{SO}_{2}$. Therefore, neither $\mathrm{CO}$ or $\mathrm{SO}_{2}$ emissions are influenced by coal loading over this range of test conditions.

The emissions of $\mathrm{NO}_{\mathrm{x}}$ are of greater interest relative to the influence of coal loading on combustor performance. Figure 30 is a graph of $\mathrm{NO}_{x}$ emissions versus equivalence ratio for the three different coal loadings. Interestingly, the lowest $\mathrm{NO}_{x}$ emissions are achieved with the fuel with the middle coal loading of 54\%. Data is presented with this fuel taken in two tests. As mentioned above Test No. 43 was taken without the slag tap torches operating while in Test No. 48 the torches were in operation. The curve through these data suggest that the torches had no influence on $\mathrm{NO}_{\mathrm{x}}$ emissions. The documented relation between $\mathrm{NO}_{x}$ emissions and equivalence ratio for the TSSC is illustrated by that curve plotted over data taken in Test Nos. 43 and 48. A typical NO emission signature would increase as the primary zone equivalence ratio was increased to a peak at 1.05. As the equivalence ratio was further increased the $\mathrm{NO}_{x}$ emissions fall off rapidly 


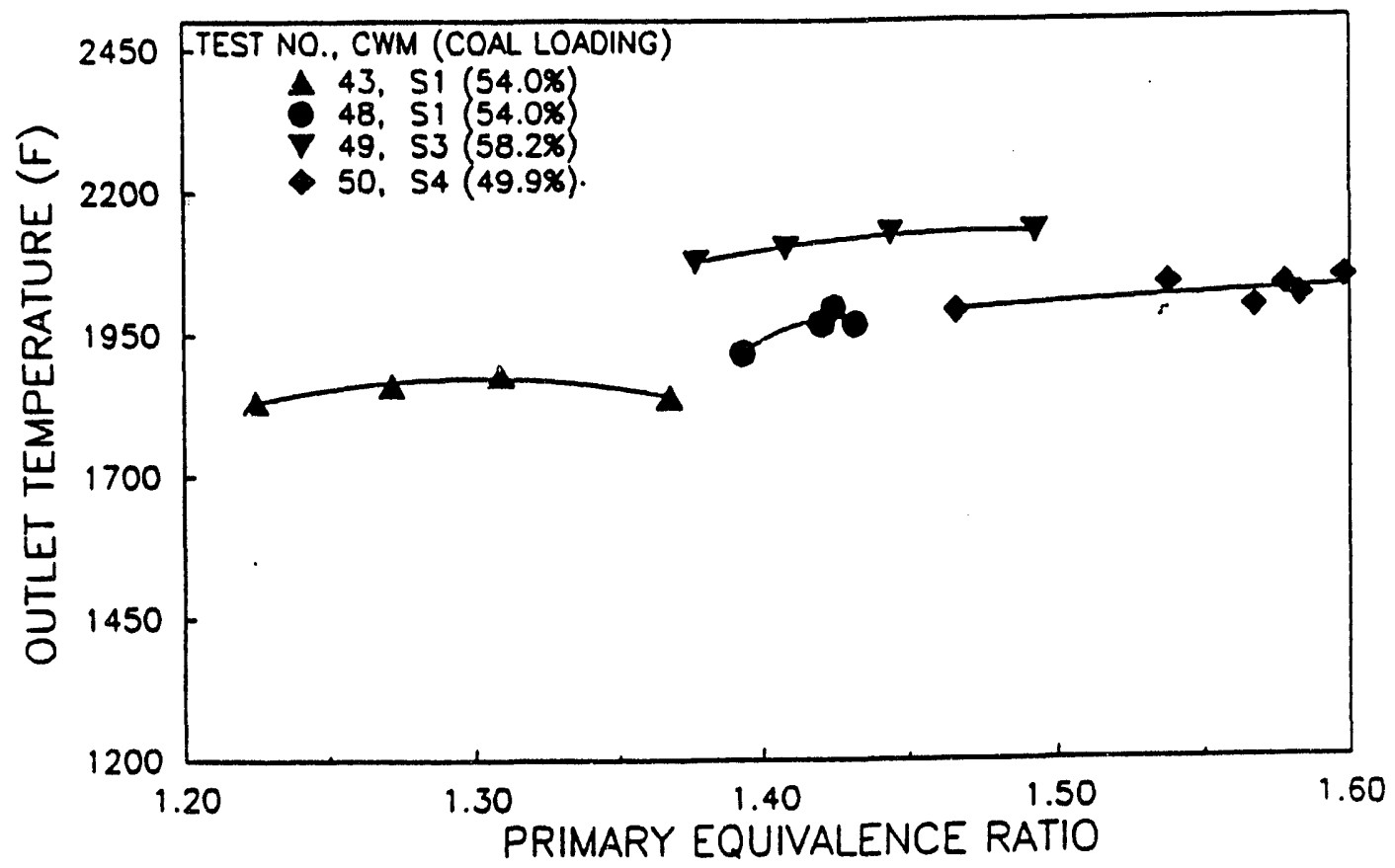

Figure 29. Outlet Temperature Profile of TSSC Burning CWMs of Varying Coal Loadings

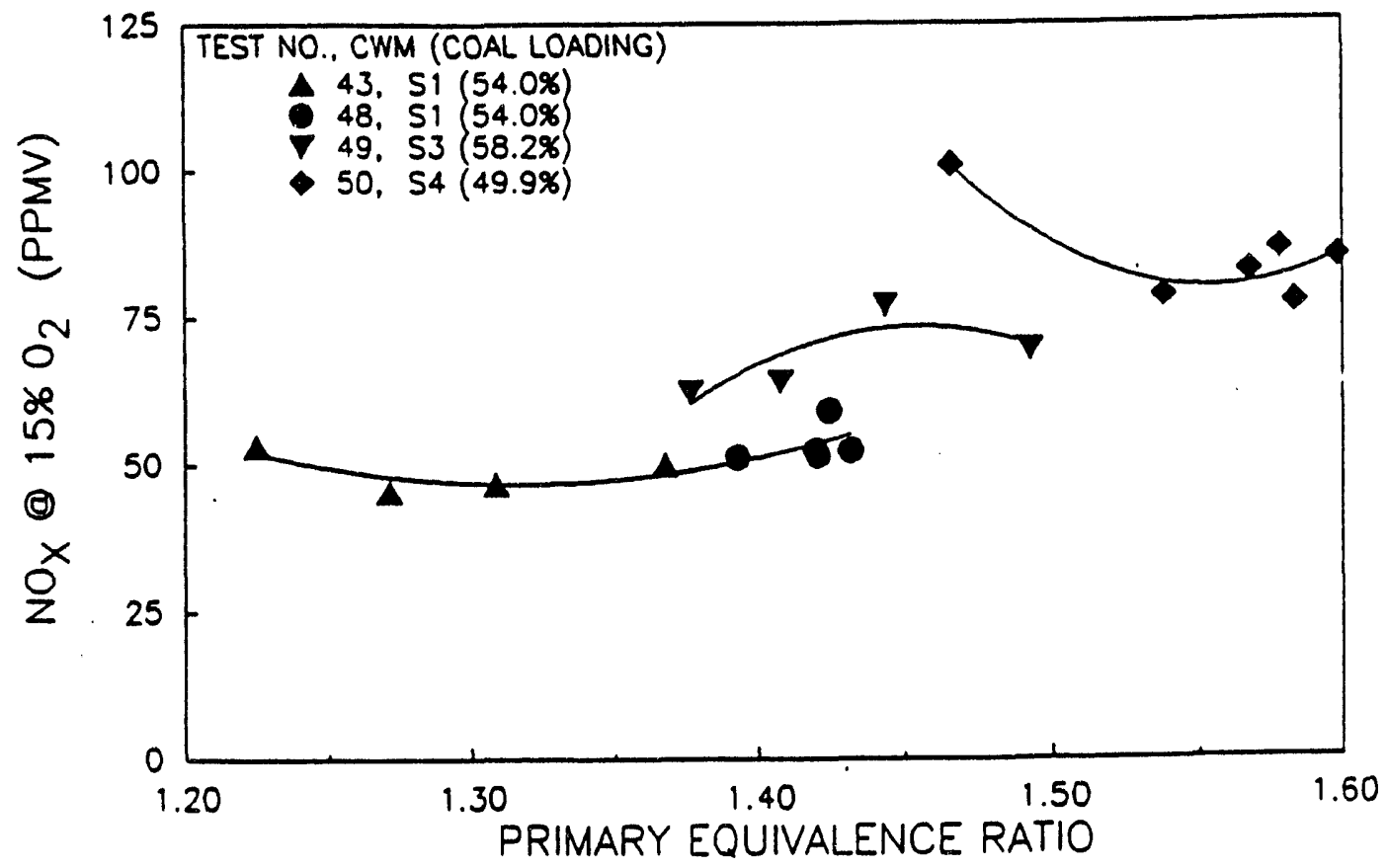

Figure 30. $\mathrm{NO}_{x}$ Emissions of TSSC Burning CWMs of Varying Coal Loadings 
to a low at 1.25 to 1.35. The emissions slowly increase with further increases in equivalence ratio. The curve through data from Test Nos. 43 and 48 in Figure 30 illustrate this trend. The figure suggests that the highest $\mathrm{NO}_{\mathrm{x}}$ emissions correspond to the lowest coal loading. This was not an expected result. Typically, as the water loading in the combustor was increased the flame temperature was decreased and correspondingly, so are the $\mathrm{NO}_{\mathrm{x}}$ emissions. This trend is exhibited when considering the data presented from Test Nos. 43, 48, and 49 . Here the $\mathrm{NO}_{x}$ emissions are increased as the coal loading was increased (and water loading was decreased). In light of the number of data points taken in Test No. 50, the data point taken at the lowest equivalence ratio could be errant and, in fact, if this data is viewed omitting that data point a convincing curve could be drawn corroborating the data from Test Nos. 43, 48, and 50.

The particulate samples indicate that the most efficient combustion was completed with "S3" the $58 \%$ coal fuel. The carbon conversion was the highest with that fuel at $99.7 \%$ and the particulate emissions are the lowest. CWM's "S1" and "S4" with lower coal loadings had worse carbon conversions at $97.2 \%$ for each. This trend can be explained by the higher water vapor concentrations in the primary zone combustor with fuels of decreasing coal loading. Higher water vapor concentrations lowers flame temperatures, which have a strong influence on system carbon conversion. The particulate emissions for tests with the low coal loading fuels was more than three times higher than Test No. 49. The particulate emissions include all unburned carbon and so carbon conversion and particulate emissions are strongly coupled. It should be noted that these data were uncorrected for equivalence ratio which presents a problem in comparing the results. This was true more for the data taken in Test No. 50 in which the average equivalence ratio was 1.55. Typically, carbon conversion should decrease as primary equivalence ratio was increased past some critical value in the range of 1.5 to 1.75. However, this value has not been established for the TSSC.

The particulate ash and dilution water analyses are also included in Table 13 for the three tests. The ash analyses of the particulate usually reflect the ash composition of the coal burned. This trend was not reflected in the data presented in Table 13 in that $\mathrm{F}_{2} \mathrm{O}_{3}$ was the largest constituent for two of the tests (48 and 49) whereas in the coal ash $\mathrm{SiO}_{2}$ was the major constituent. However, the three major constituents in the particulate ash analysis of $\mathrm{Al}_{2} \mathrm{O}_{3}, \mathrm{Fe}_{2} \mathrm{O}_{3}$, and $\mathrm{SiO}_{2}$ are also the major constituents in the coal ash. The dilution water analysis indicates the presence of sulfur, metal lons from the ash, and dissolved alkalis.

The last combustor performance parameter is shown in Table 12 under the heading ash balance. The primary zone slag capture is the amount of coal ash separated by the impactor in the slagging combustor. In the TSSC the primary zone slag capture has varied from $10 \%$ to $85 \%$. The combustor typically operates with a slag capture in the range of 55 to $70 \%$. The values in Table 12 are substantially lower due to the reduced length of the primary zone. Typically, the primary zone was 24 inches from injector tip to impactor. In these tests the primary zone length was reduced to 16 inches. This reduction was necessary to accommodate the water quenched slag pit for on-line slag removal. In comparing results from these tests taken with varying coal loading the highest capture was achieved with the baseline fuel with the median coal loading. The accuracy of the slag capture was $\pm 10 \%$ so determining any trend from the data in Table 12 is difficult. The data does suggest that the influence of coal loading on slag capture was not great.

Table 12 also includes the percentage ash emitted. This value was calculated from the particulate sample analysis. The primary zone slag capture and ash emission should balance to account for all the slag put into the system. Unfortunately, two factors introduce error in this mass balance. First, in the TSSC without a PRIS a considerable portion of ash was frozen in the secondary combustor. Determining the amount of slag trapped in this region was not completed as it would have required a complete rig tear down. Secondly, the measurement of primary zone slag capture and ash emission are accurate to within only $10 \%$ so a potential $20 \%$ measurement error was 
present. The imbalance in the mass balance is included in Table 12 as both a percentage of the ash input and the weight of the unaccounted for ash. The worst data balance was obtained with the baseline fuel in Test No. 48. Determining a trend in slag capture with coal loading was not possible with the data presented.

In summary, three tests were completed with CWMs of varying coal loadings from 50 to $58.2 \%$. The TSSC was capable of utilizing all three fuel with little noticeable impact on combustor performance. The coal loading had a substantial impact on the fuel theology with the CWM of highest loading being more difficult to handle. The emissions varied only slightly with $\mathrm{NO}_{x}$ emissions increasing with increasing coal loading. Combustor outlet temperature also increased with increasing coal loading. Carbon conversion was determined to increase slightly with increasing coal loading. The primary zone slag capture was not strongly influenced by coal loading.

\section{Ash Concentration}

The influence of coal ash on combustor performance has been investigated in three tests with CWMs "S1", "S6", and "S7" with coal ash loadings of 3.80, 8.84, and 12.81\%, respectively. The properties or the three CWMs and the tests (Nos. 48, 51, and 52) they were used in are included in Table 11. The fuels were formulated to possess similar properties with the exception of coal ash loading. This goal was achieved to a large extent, but completely uncoupling changes to the ash loading from all the other CWM properties is not possible. In particular, heating value, volatile content, and fixed carbon all decrease with increasing coal ash concentration. The decrease of the latter two are a direct result of increased ash displacing volatiles and carbon. The heating value drops due to coal ash (without any heating value) displacing the carbon and volatiles (combustible). The composition of the ash does not vary significantly as the concentration in the coal was increased.

The combustor exhibited good operation with all three fuels. The combustor tests were operated at nearly identical conditions as listed in Table 12. Testing was completed in the subscale TSSC with the continuous slag removal system employing a water quench bath with a lock hopper in a conical primary zone combustor with the baseline injector configuration. The slag tap torches were operated continuously throughout all three tests. The operating parameters included in Table 12 are similar for the three tests.

The largest variation in test conditions was in primary zone equivalence ratio. The tests were to be operated at an equivalence ratio of 1.38. The discrepancy stems from the additional fuel input through the slag tap torches.

The operation of the combustor was similar in the three tests being discussed. The TSSC design is tolerant to a three-fold increase in coal ash concentration without any ill effects on combustor performance. In Test 52 with the highest ash loading more frequent adjustments to the rig back pressure valve were required. The back pressure valve was used to control the combustor pressure. Adjustments to this valve are required as air flow rate, gas temperature, particulate loading, and quench water flow rate vary. During Test 52 (highest ash concentration) the increased adjustments to the valve were perceived to be caused by the increased ash emissions from the TSSC. Analysis of the particulate sample taken during that test do not support that perception because the particulate emissions were determined to be lower than in the other tests.

The outlet temperature measured in the three tests was uniform and nearly constant at an average near $1970^{\circ} \mathrm{F}$ as shown in Table 12. This trend is further illustrated in Figure 31, which is a plot of outlet temperature versus equivalence ratio for Tests 48,51 , and 52 . The outlet temperature was measured at the exit of the secondary combustor. The table and figure indicate that coal ash concentration over the range of 3.7 to $12.3 \%$ has no influence on outlet temperature. 


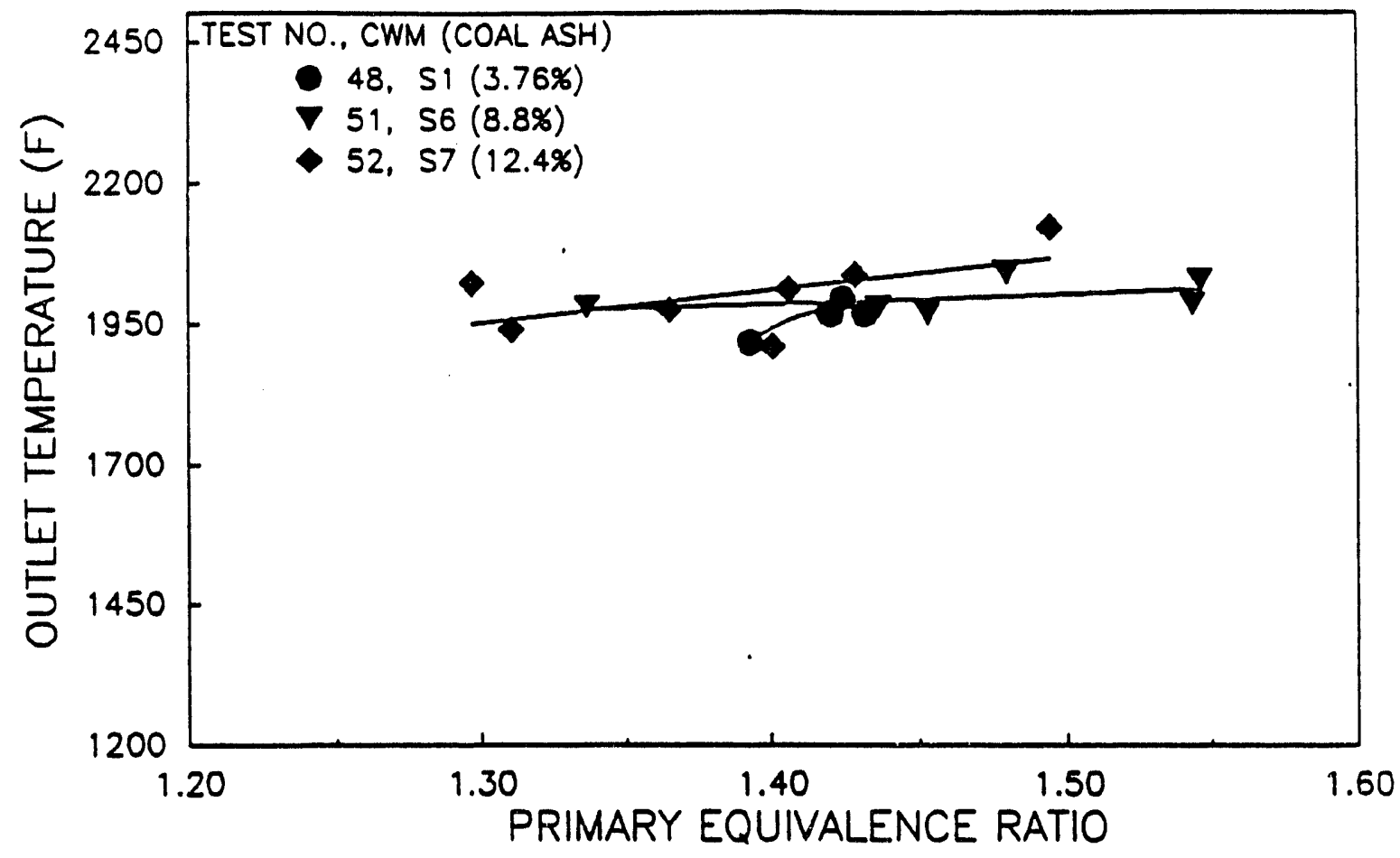

Figure 31. Varlation of Outlet Temperature With Fuels of Varying Coal Ash Concentration

Emissions are summarized in Table 12 and in Figure 32. The values in Table 12 are averaged over the entire test. Emissions of $\mathrm{CO}$ were below $15 \mathrm{ppmv} @ 15 \% \mathrm{O}_{2}$ for all fuels tested. $\mathrm{SO}_{2}$ emissions are a function of the sulfur loading of the fuel as nearly all the sulfur input into the combustor in the fuel was converted to $\mathrm{SO}_{2}$. Therefore, neither $\mathrm{CO}$ or $\mathrm{SO}_{2}$ emissions are influenced by coal ash concentration over this range of test conditions. Likewise, the emissions of $\mathrm{NO}_{x}$ are not influenced by ash concentration. Figure 34 is a graph of $\mathrm{NO}_{x}$ emissions versus equivalence ratio for the three different coal ash concentrations. Test Nos. 48 and 43 were completed with the same CWM ("S1"), but in Test 43 the slag tap torches were not in operation. Figure 32 indicates that $\mathrm{NO}_{\mathrm{x}}$ emissions are not influenced by coal ash concentration significantly. Data included from Test 43 shows the influence of the slag tap torches rather than the coal ash loading.

Post-test inspection of the combustor after each of the three tests revealed that as coal ash concentration was increased slag coatings and accumulations increase. In Test 48 the combustor was lightly coated with slag and little slag reached the water bath below the slag tap. After Tests 51 and 52 increasing slag accumulations were seen particularly below the slag tap. In both cases slag did not fully reach the water bath, rather froze/bridged across the insulation located between the slag tap and water bath. The amount of slag below the slag tap after each test was roughly proportional to the ash concentration of the CWM burned. The slag below the slag tap increased from 7.2, 16.5, and 45.4 lbs for Tests $48(3.7 \%), 51(8.8 \%)$, and $52(12.8 \%)$, respectively. The secondary combustor had increasing slag accumulations with increasing ash concentration that were visually obvious. 


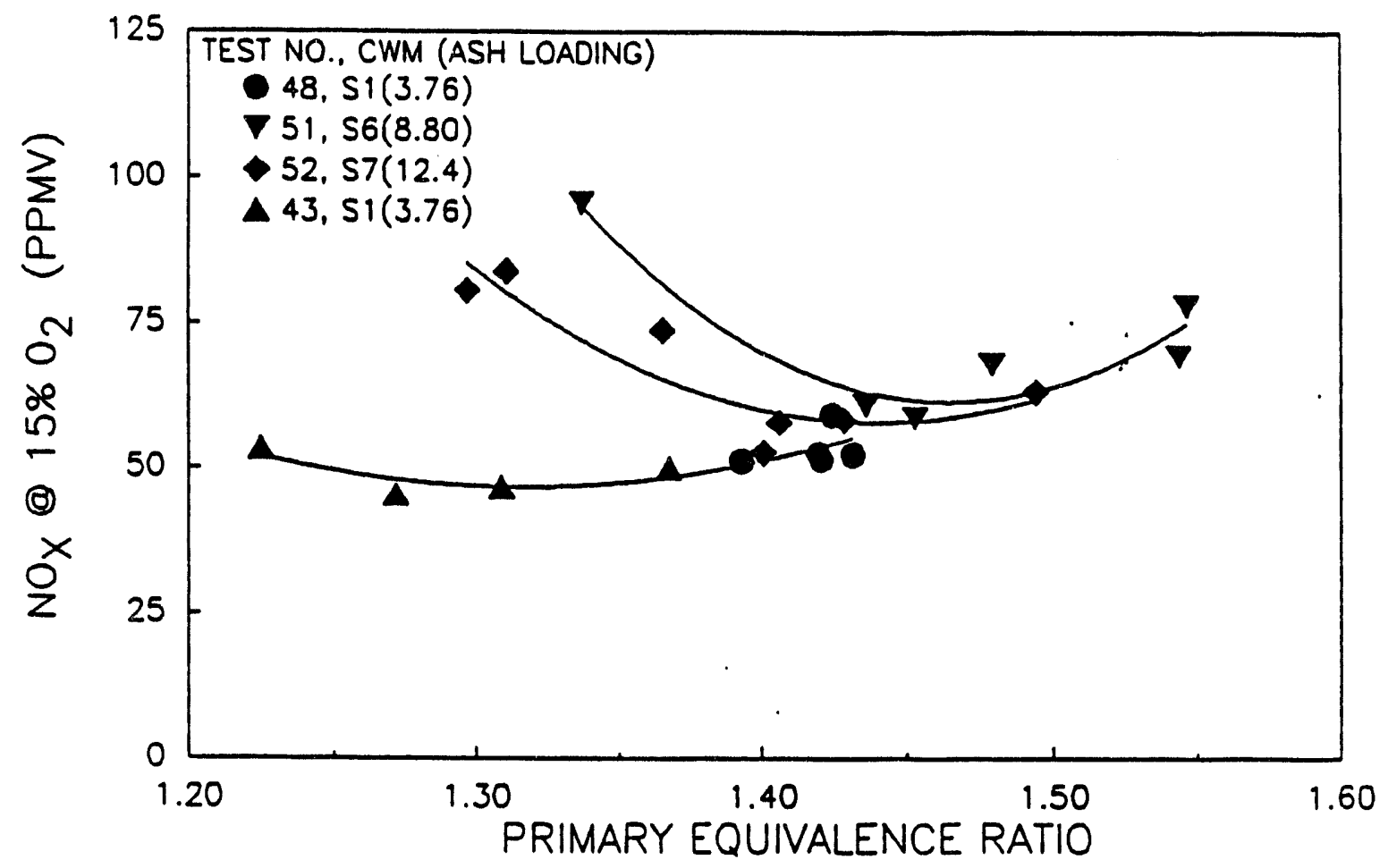

Figure 32. Variation of $\mathrm{NO}_{x}$ Emissions With Fuels of Varying Coal Ash

The higher ash coal led to an apparent greater damage to the refractory. The casting in the combustor was reused for all three tests. The inner refractory used in the combustor was a high density alumina-silica castable - Thermal Ceramics Kaocrete HPM 90. The degradation of this material was noticeably escalated as the coal ash concentration was increased. The degradation was typical of the refractory damage observed after many tests completed with the TSSC. The refractory over a number of tests first, cracks, then pits, and finally erodes to the point where recasting was required. The higher ash loading did accelerate this damage. These tests illustrate that the amount of slag the refractory is exposed to has an influence on its life. Furthermore, these results suggest that the amount of slag may be the predominant factor controlling refractory life.

The particulate samples, included in Table 13, indicate that the most efficient combustion was completed burning "S7" with the highest coal ash. The carbon conversion was the highest with that fuel at $99.7 \%$ and the particulate emissions are the lowest. CWMs "S1" and "S6" with decreasing ash concentration exhibited decreasing carbon conversions at 99.0 and $97.2 \%$, respectively. This trend suggests that coal ash actually improves combustion efficiency. One explanation of this measurement was that ash may act to break apart burning coal particles, so that, increasing coal ash results in greater coal fragmentation into finer coal particles during the combustion process. Finer coal particles would then be completely combusted in a significantly reduced residence time.

The particulate ash and dilution water analyses are also included in Table 13 for the three tests. The ash analyses of the particulate usually reflects the ash composition of the coal burned. This trend was reflected in the data presented in Table 13. The three major constituents in the particulate ash analysis of $\mathrm{Al}_{2} \mathrm{O}_{3}, \mathrm{Fe}_{2} \mathrm{O}_{3}$, and $\mathrm{SiO}_{2}$ are also the major constituents in the coal ash. In Tests 51 and 52 these constituents are present in the same order of increasing concentrations for both the particulate and coal ash analyses. The dilution water analysis shows the presence of sulfur, metal ions from the ash, and dissolved alkalis. 
The last combustor performance parameter is shown in Table 12 under the heading ash balance. The primary zone slag capture is the amount of coal ash separated by the impactor in the slagging combustor. In the TSSC the primary zone slag capture has varied from $10 \%$ to $85 \%$. The combustor typically operates with a slag capture in the range of 55 to $70 \%$. The values in Table 12 are substantially lower due to the reduced length of the primary zone. The accuracy of the slag capture measurement was $\pm 10 \%$ for the low ash coal but improves as the ash concentration was increased. This improvement results from increased slag weight measurements relative to the accuracy of the scale, which are used to determine the slag capture. The data suggests that coal ash concentration improves primary zone slag capture.

The particulate emission measurements included in Table 12 support this conclusion that increasing coal ash concentration improves primary zone slag capture. This measurement shows the highest particulate emissions (2034 ppmm) being measured with the baseline fuel that contains the lowest coal ash. In general, the higher the particulate emissions the lower the slag capture. This was obvious when considering an ash mass balance in the system. Ash not captured as slag in the primary zone was either emitted from the combustor in the form of particulate ash or frozen in the system between the primary zone and exhaust. In Tests 48, 51, and 52 the particulate emissions decrease with increasing coal ash concentration, which suggests that the slag capture should increase. Both the particulate measurements and the slag capture measurements support this observation.

The error in the mass balance is included in Table 12 as both a percentage of the ash input and the weight of the unaccounted for ash. The worst data balance was obtained with CWM "S6" with the medium ash level.

In summary, three tests were completed with CWMs of varying coal ash concentrations from 3.7 to $12.8 \%$. The TSSC was capable of utilizing all three fuels with little noticeable impact on combustor performance. The CWMs all exhibited similar handling properties. Gaseous emissions were not influenced by coal ash concentration. Carbon conversion was determined to increase with increasing coal ash concentration. The primary zone slag capture, although large measurement errors exist, did appear to improve as coal ash concentration was increased. Higher coal ash resulted in faster refractory degradation and larger accumulations of slag in the secondary combustor.

\section{NeAdditlves}

CWM "S5" was blended without the addition of the fuel additives normally included. The properties of this CWM are included in Table 11. This fuel contains no dispersant (A-23) or stabilizer (Flocon). Studies at Sandia Laboratory have found that these additives inhibit CWM atomization. By aiding the atomization process an improvement in combustion performance should be realized. The fuel also differs from the baseline CWM ("S1") in several other ways. The coal grind has a bimodal distribution, which is shown through an increased mean size. The coal loading was substantially lower than in the baseline with a resulting lower heating value. The CWM was intentionally blended with these properties as a potential hybrid CWM. The CWM was blended and shelved for approximately 10 months.

The operating conditions and major results for this test are included in Table 12. In Test 53 the combustor was operated at standard conditions with a slightly lower equivalence ratio. In general, the combustor exhibited below average performance. In particular, the $\mathrm{CO}$ emissions were higher and the slag capture was substantially lower. Another indication of poor combustor performance was the largo amount of char found in the water bath after the test. While mixing the CWM, a thick "gelatin" like quality was noted. The thickened fuel caused a higher than normal fuel pump pressure 
and eventually led to a clog in the CWM delivery line upstream of the mass flowmeter. The clog forced an early shut-down of the test.

The thickened appearance of the CWM was not supported by the viscosity measurements made after the fuel was prepared. In Table 11 a viscosity of $375 \mathrm{cp}+100 / \mathrm{sec}$ is listed. While this value is stightly higher than the typical specification of $300 \mathrm{cp}$, the viscosity measurement does not corroborate with the CWM "gelatinatious" appearance. Without the addition of an antibacterial agent the CWM may have been altered biologically while sitting for the past 10 months, but tests of the CWM showed no abnormalities.

The particulate sample taken in this test has been analyzed and data are included in Table 12 and 13. The carbon conversion was in-line with other tests and the particulate emissions are slightly improved. These results are slightly contradictory to the above statements that the combustor exhibited poorer performance than other tests.

In conclusion, a CWM with no additives has been tested and exhibited poorer combustion performance. The CWM appeared to be substantially thicker than other fuels tested leading to a clog in the fuel dellvery line.

\section{Coal Particle Siza}

The influence of coal particle size on combustor performance has been investigated in three tests with CWMs "S1", "S8", and "S9" with coal particle top-8izes of 45, 25, and 75 microns, respectively. The properties of the three CWMs and the tests (Nos. 48, 54, and 55) they were used in are included in Table 11. The fuels were formulated to possess similar properties with the exception of coal particle size. This goal was achieved to a large extent.

The combustor exhibited good operation with all three fuels. The combustor tests were operated at nearly identical conditions as listed in Table 12. The operating parameters included in Table 12 are similar for the three tests.

The largest variation in test conditions was in primary rone equivalence ratio. The tests were to be operated at an equivalence ratio of 1.38. The discrepancy stems from the additional fuel input through the slag tap torches.

The operation of the combustor was similar in the three tests being discussed. The TSSC design is tolerant to a three-fold increase in coal particle top-size without any ill effects on combustor performance. Test 55 was a slightly smoother test than either of the other tests in terms of combustor outlet temperature and pressure and the need for back pressure valve adjustment. The back pressure valve was used to control the combustor pressure. Adjustments to this valve are required as air flow rate, gas temperature, particulate loading, and quench water flow rate vary.

The outlet temperature measured in the three tests was fairly uniform at an average of $2000^{\circ} \mathrm{F}$ as shown in Table 12. This trend is further illustrated in Figure 35, which is a plot of outlet temperature versus equivalence ratio for Tests 48,54 , and 55. The outlet temperature was measured at the exit of the secondary combustor. The table and figure indicate that coal particle top-size over a range of 25 to 75 microns has no detectable influence on outlet temperature over a variation of primary equivalence ratio of 1.3 to 1.7. 


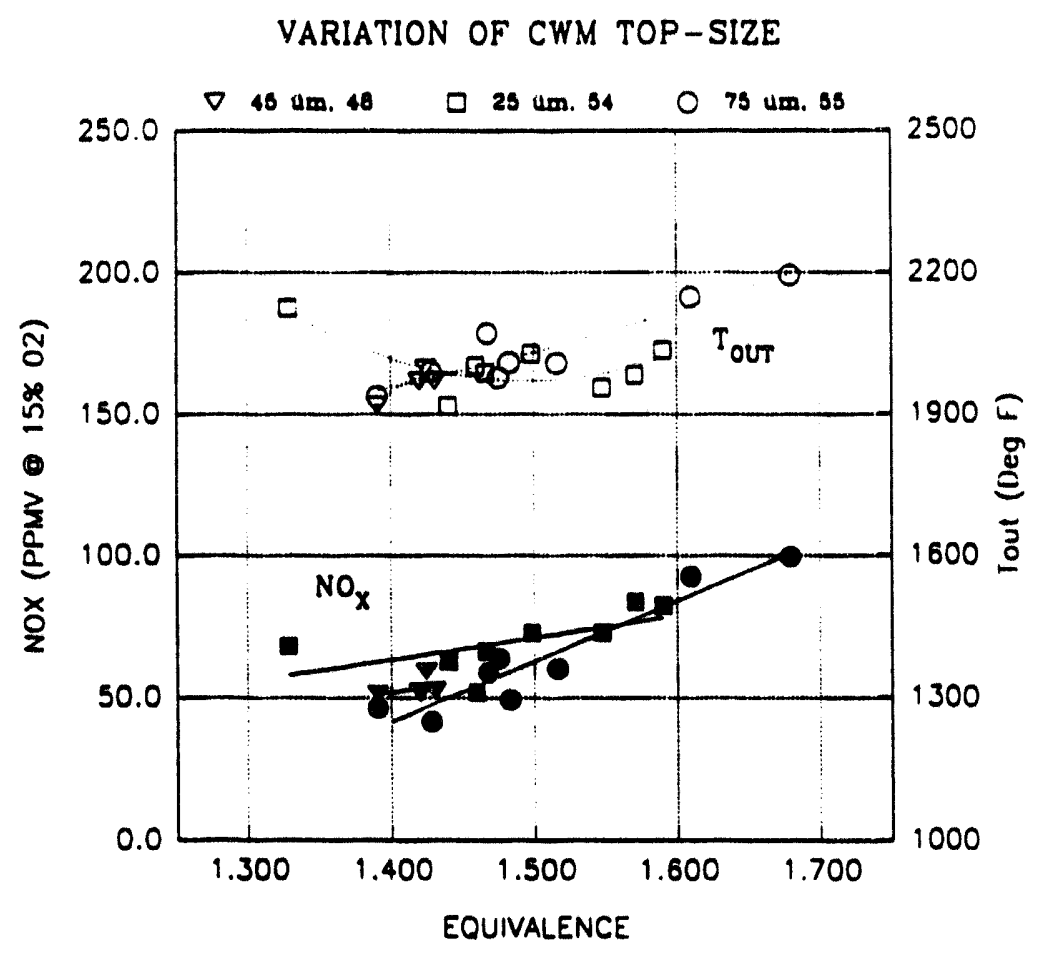

Figure 33. Outhat Temperature and Emisolon Characteristice of TSSC Burning CWMs Made From Coals of Varying Particle Slzo

Emissions are summarized in Table 12 and in Flgure 33. The values in Table 12 are averaged over the entire test. Emissions of $\mathrm{CO}$ were below $20 \mathrm{ppmv} @ 15 \% \mathrm{O}_{2}$ for all fuels tested. $\mathrm{SO}_{2}$ emissions are a function of the sulfur loading of th: $\theta$ fuel as nearly all the sulfur input into the combustor in the fuel was converted to $\mathrm{SO}_{2}$. Therefore, neither $\mathrm{CO}$ or $\mathrm{SO}_{2}$ emissions are influenced by coal particle size over this range of test conditions. Figure 33 is a graph of $\mathrm{NO}_{x}$ emissions versus equivalence ratio for the three different coal particle sizes. Figure 33 indicates that $\mathrm{NO}_{\mathrm{x}}$ emissions are not influenced by coal particle size significantly.

Post-test inspection of the combustor after each of the three tests revealed that coal particle top-size variations of 25 to 75 microns has no noticeable impact on slag coatings and accumulations. In the three tests being compared the combustor was lightly coated with slag and little slag reached the water bath below the slag tap. Accumulations of slag in the secondary combustor were light.

Analysis of particulate samples were completed to provide the carbon conversion and particulate emissions data included in Table 12. The analysis of the three samples is included in Table 13. The particulate samples indicate that the most efficient combustion was completed burning " $S 9$ " with the largest coal particle top-size. The carbon conversion with that fuel was the highest at $98.5 \%$ and the particulate emissions are the lowest. CWM's "S1" and "S8" with consecutively finer grinds exhibited carbon conversions of 97.2 and $97.9 \%$, respectively. The data does not show a distinct trend with coal particle size. Given the small variations in carbon conversion these results may reflect measurement errors. An alternative explanation assuming that the carbon conversion does vary as indicated may come from an examination of the atomization process. It has been surmised that CWM atomization is improved by a mix of small and large particles, rather than all small particles. If a mix of large and small particles can be atomized more finely than a fluid containing only small particles then the carbon conversion should trend with the size of the droplets generated rather the size of the coal particles. 
The particulate ash and dilution water analyses are also included in Table 13 for the three tests. The ash analyses of the particulate usually reflect the ash composition of the coal bumed. This trend is reflected in the data presented in Table 13. The three major constituents in the particulate ash analysis of $\mathrm{AL}_{2} \mathrm{O}_{3} \mathrm{Fe}_{2} \mathrm{O}_{3}$, and $\mathrm{SIO}_{2}$ are also the major constituents in the coal ash. In Tests 54 and 55 these constituents are present in the same order of increasing concentrations for both the particulate and coal ash analyses. The dilution water analysis shows the presence of sulfur, metal lons from the ash, and dissolved alkalls.

In comparing ash balance results from these tests taken with varying coal particle size the highest slag capture was achieved with the CWM of a medium coal grind (45 microns). The accuracy of the slag capture measurement was $\pm 10 \%$ for the CWM's tested. Both the fine and coarse coal grinds had similar slag capture efficlencies. The decrease in slag capture with either increasing or decreasing coal particle size from 45 microns was not fully understood. Measurement error could certainly contribute to these findings. This result can also be explained by the influence of particle size on atomization as discussed in the previous section.

In summary, three tests were completed with CWMs of varying coal particle top-size of 25 to 75 microns. The TSSC was capable of utilizing all three fuels with little noticeable impact on combustor performance. The CWMs all exhiblted similar handling properties. Gaseous emissions were not influenced by coal particle size. Carbon conversion was only weakly influenced by coal particle size with the highest conversion obtained with the largest top-size. The primary zone slag capture, although large measurement errors exist, did appear to get worse as coal particle top-size was increased or decreased from 45 microns.

\section{Coal Seame}

The difference in combustor performance with CWM's made from four different coal seams has been investigated in four tests with CWMs "S1", "S10", "S11", and "S12". These mixtures have been produced from coals taken from the Kentucky 4AE Ekhom, Upper Freeport, Soldier Creok, and Illinois No. 6. seams, respectively. These seams are potential sources of coal for the coal-fueled S-ntaur sited in different regions of the country. The properties of the four CWMs and the tests (Nos. 48, 56, 57, and 58) they were used in are included in Table 11. The fuels were formulated to possess similar properties with the exceptlon of the coal seam used to produce the slurry. The coal seam has a substantial impact on fuel properties. In particular, these seams show significant variations in volatile content and ash loading. A more complete comparison of the fuels is included in Section 5.2.

The combustor exhibited good operation with all four fuels. The combustor tests were operated at nearty identical conditions as listed in Table 12. The operation of the combustor was similar in the four tests being discussed. The TSSC design is capable of utilizing bituminous coals from different coal seams located in different regions of the country. The principle differences in operation of the combustor with these fuels occurred in Tests 56 and 58. In Test 56 the back pressure valve required more frequent purges. With CWM "S10" the increased ash loading of the coal lead to the increased number of purges. During Test 58 the fuel exhibited poorer fuel pumping cliaracteristics with variations of plus/minus $7.6 \%$. Analysis of the fuel sampled at the combustor inlet has indicated rather standard properties. The fuel pump has operated normally in subsequent tests. A heavier build-up in the fuel filters was noted at the conclusion of Test 58. This blockage was the probable cause of the fluctuations in the fuel flow rate. A more robust feed system could be designed to adequately deliver CWM "S12".

The outlet temperature measured in the four tests was fairly uniform at an average of $1979^{\circ} \mathrm{F}$ as shown in Table 12. This trend is further illustrated in Figure 34, which is a plot of outlet temperature versus equivalence ratio for Tests $48,56,57$, and 58 . The outlet temperature was measured at the 


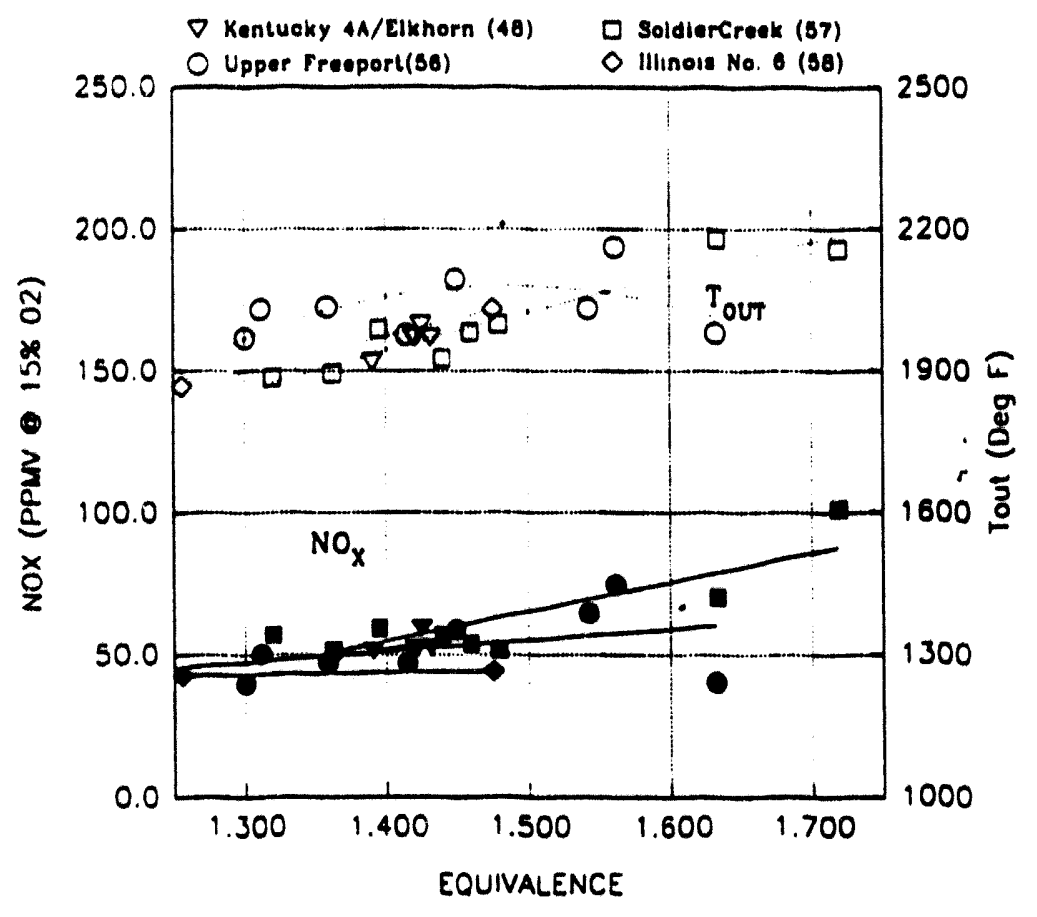
Figure 34. Outlet Temperature and Emlealon Charactorietles of TsSC Buming CWMs
Made From Coals From Difforent Seams

exit of the secondary combustor. The table and figure indicate that the coal seam has little influence on outlet temperature. The highest temperatures on average resulted from the Upper Freeport coal which has a medium volatile content of $25.8 \%$ versus 35 to $39 \%$ for the other coals. This coal also exhibited the highest carbon conversion at $\mathbf{9 9 . 8 \%}$ which should result in a higher outlet temperature.

Emissions are summarized in Table 12 and in Figure 34. The values in Table 12 are averaged over the entire test. Emissions of CO were below 25 ppmv $115 \% \mathrm{O}_{2}$ for all fuels tested. $\mathrm{SO}_{2}$ emissions are a function of the sulfur loading of the fuel as nearly all the sulfur input into the combustor in the fuel was converted to $\mathrm{SO}_{2}$. Therefore, neither $\mathrm{CO}$ or $\mathrm{SO}_{2}$ emissions are influenced significantly by coals taken from different coal seams. Likewise, the emissions of $\mathrm{NO}_{x}$ are not influenced by these coals from different bituminous seams. Figure 34 is a graph of $\mathrm{NO}_{x}$ emissions versus equivalence ratio for the four different coal seams. Figure 34 indicates that $\mathrm{NO}_{x}$ emissions are not influenced by coals from different seams significantly.

Post-test inspection of the combustor after each of the four tests revealed that the slag coatings are a strong function of the ash content of the coal. Tests 48, 57, and 58 all had light coatings on the primary zone wall and in the secondary combustor, while in Test 56 the slag coatings and accumulations are heavier particularty in the secondary combustor. In Test 58 a greater slag capture in the primary zone was demonstrated.

The particulate sample analyses in Table 13 indicate that the most efficient combustion was completed buming "S10" from the Upper Freeport seam. The carbon conversion was the highest with that fuel at $99.8 \%$ and the particulate emissions are the lowest. The CWMs made from the coals from the different coal seams all bumed with carbon conversions above $98 \%$, higher than the baseline coal at $97.2 \%$. 
The particulate ash and dllution water analyses are also included in Table 13 for the three tests. These data show typical trends of the ash composition reflecting the composition of the particulate ash.

Comparing ash balance results presented in Table 12 from these tests taken with coals from different seams the higheet slag capture was achleved with the coal from the Illinols No. 6. The accuracy of the slag capture measurement was $\pm 10 \%$ for the CWM's tested. The other seams demonstrated slag captures ranging from 23 to $37 \%$. The slag capture values reported in Table 12 trend most significantly with the $\mathrm{Fe}_{2} \mathrm{O}_{3}$ content of the coal ash. Iron oxide has been found to reduce slag viscosity at constant temperature in reducing environments. In these tests where the $\mathrm{Fe}_{2} \mathrm{O}_{3}$ content varied from $20.08 \%$ (S12), $12.12 \%$ (S1), $11.92 \%$ (S10), to $7.67 \%$ (S11) the slag captures varied from $54 \%, 37.2 \%, 31 \%$, to $23 \%$, respectively. The primary zone slag capture and ash emission should balance to account for all the slag put into the system. The orror in the mass balance is included in Table 12 as both a percentage of the ash input and the woight of the unaccounted for ash. The worst data balance was obtained with CWMs "S10" and "S11".

In summary, four tests were completed with CWMs made from coals from different coal seams. The coal seams used are a Kentucky 4AEIkhom blend, Upper Freeport, Soldler Creek, and Illinois No. 6. All four seams are bltuminous coals that potentially will be supplies for the Coal-Fueled Centaur as it was sited in different regions of the country. The TSSC was capable of utllizing all four fuels with little notlceable impact on combustor performance. The CWMs exhibited similar handling properties except for the slurry from the Illinois No. 6 seam which was more difficult to pump. Gaseous emissions were not influenced by the coal seam. The highest carbon conversion was obtained with the coal from the Upper Freeport seam which has the lowest volatile content. The primary zone slag capture, although large measurement errors exist, was highest with the Illinois No. 6 , which had the highest iron content in the ash.

\section{CoslEunl Spocification}

Testing conducted in the TSSC to study the influence of fuel properties on combustor performance has been completed to design a fuel specification for the F/S combustor. The design goal of the TSSC was to make a system that could use an extremely large range of fuel properties. The test results indicate that the design goal has been met.

Testing has indicated that the combustor can efficiently burn slurrles with coal loadings ranging from 49.9 to $58.2 \%$, ash content of 3.8 to $12.8 \%$, coal particle top-size of 25 to 75 microns, and bituminous coals from a large number of seams located regionally in the U.S. The tests have indicated that only high coal loading and CWMs formulated without any addittves severely impact the combustor performance. Fuels with high coal ash lead to faster refractory damage, but do not impact combustor performance while the refractory was intact.

Based on these test results and all earlier tests, the tuel specification for full scale combustor testing has been set and is included in Table 14. These fuel properties do not represent limits for ash concentration, coal loading, etc., but are the fuel properties that have consistently yielded the best system performance results. The fuel specification for the coal-fueled engine has not yet been fully determined. with the results obtained in this study, it is known that the combustor can be fueled with a considerably broader range of CWM properties than have been used in the past. 
Table 14. Slurry Properties for Full-Scale Combustor Testing

\begin{tabular}{|c|c|}
\hline Batch & w \\
\hline Coal Source & Kentucky 4AVElkhorn \\
\hline Slurry Loading & $54.1 \mathrm{wt} \%$ \\
\hline Ash Content & 2.94\% (Slurry Basis) \\
\hline $\begin{array}{l}\text { Particle Size } \\
\text { Top size } \\
\text { Mean Size }\end{array}$ & $\begin{array}{l}45 \mu \mathrm{m} \text { (98.7\% passing) } \\
11.9 \mu \mathrm{m}\end{array}$ \\
\hline $\begin{array}{l}\text { Slury Viscosity } \\
0100 \mathrm{sec}^{-1} \\
-1000 \mathrm{sec}^{-1}\end{array}$ & $\begin{array}{l}210 \mathrm{cp} \\
305 \mathrm{cp}\end{array}$ \\
\hline Slurry LHV & 7064 Btu/b \\
\hline Volatile Matter & $34.33 \%$ (Coal basis) \\
\hline Sulfur Content & $0.75 \%$ (Coal basis) \\
\hline Nitrogen Content & $1.48 \%$ (Coal basis) \\
\hline $\begin{array}{l}\text { Alkall Content } \\
\mathrm{Na}_{2} \mathrm{O} \\
\mathrm{K}_{2} \mathrm{O}\end{array}$ & $\begin{array}{l}0.63 \% \text { (Coal Ash basis) } \\
1.08 \% \text { (Coal Ash basis) }\end{array}$ \\
\hline $\begin{array}{l}\text { Ash Fluid Fusion Temperature } \\
\text { Reducing } \\
\text { Oxidizing }\end{array}$ & $\begin{array}{l}2497^{\circ} \mathrm{F} \\
2655^{\circ} \mathrm{F}\end{array}$ \\
\hline
\end{tabular}

\subsection{INJECTOR DEVELOPMENT}

The original fuel injector used in this program was designed and developed in the previous program. In the TSSC the design fuel flow was $150 \mathrm{pph}$ and the performance was satisfactory. The only obvious shortcoming was the amount of air assist required was approximately 1 pound of air per 1 pound of fuel. This air has to be elther supercharged from the compressor discharge or compressed from amblent. Elther way power is required which detracts from the overall package performance. An effort was made to improve the atomization by modifying the tip where the fuel and air assist mix as shown in Figure 35. The results of this modification on atomization are shown in Figure 36 and on combustor performance specifically carbon monoxide emissions in Table 15.

When the design was scaled up for a single injector TSSC (flow $=600 \mathrm{pph}$ ) or for the full size combustor ( 4 injector flow $=1500 \mathrm{pph}$ or single injector flow $=6000 \mathrm{pph}$ ) it became obvious that the existing design was deficient. The resultant design featured air assist on both sides of the fuel spray introduced through annull rather than discrete holes. This design was satisfactory for the single 


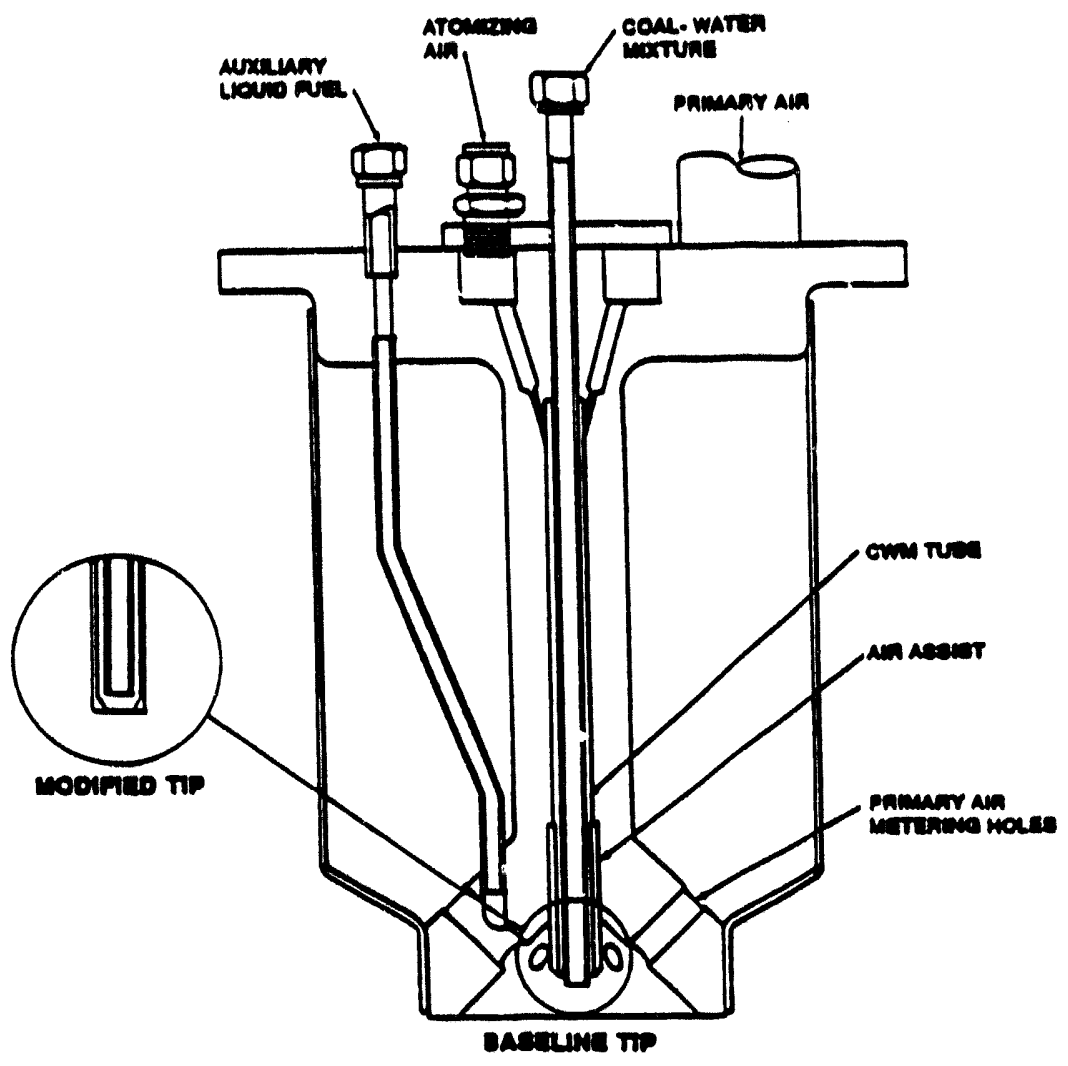

Flgure 35. CWM Fuel Injector With Baseline and Modifled Alr AsslstFuel Tlp

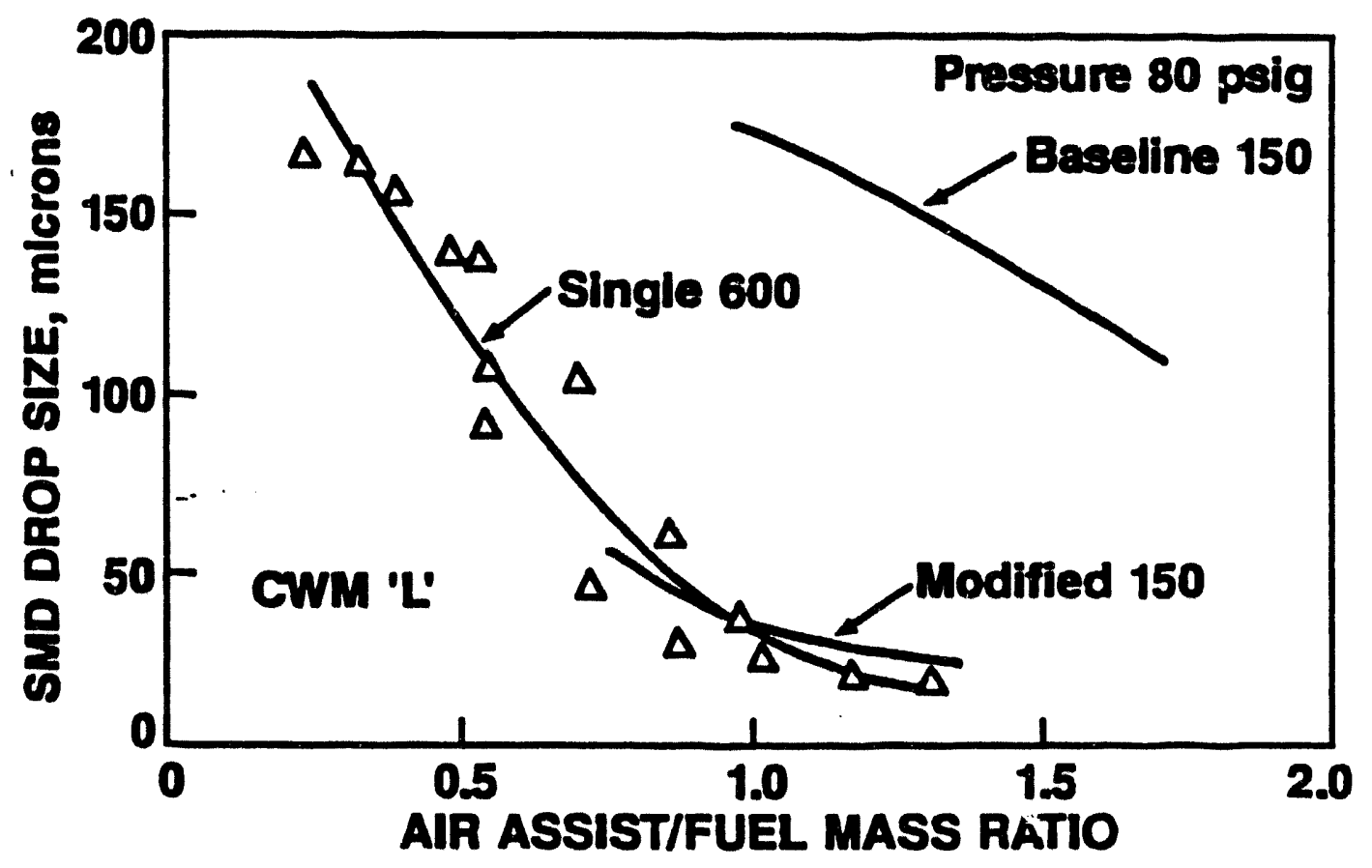

Figure 36. Drop-Slze Characteristics of $600 \mathrm{pph}$ Injector 
Table 15. Results With Modified Air Assist and Fuel Tip Assembly

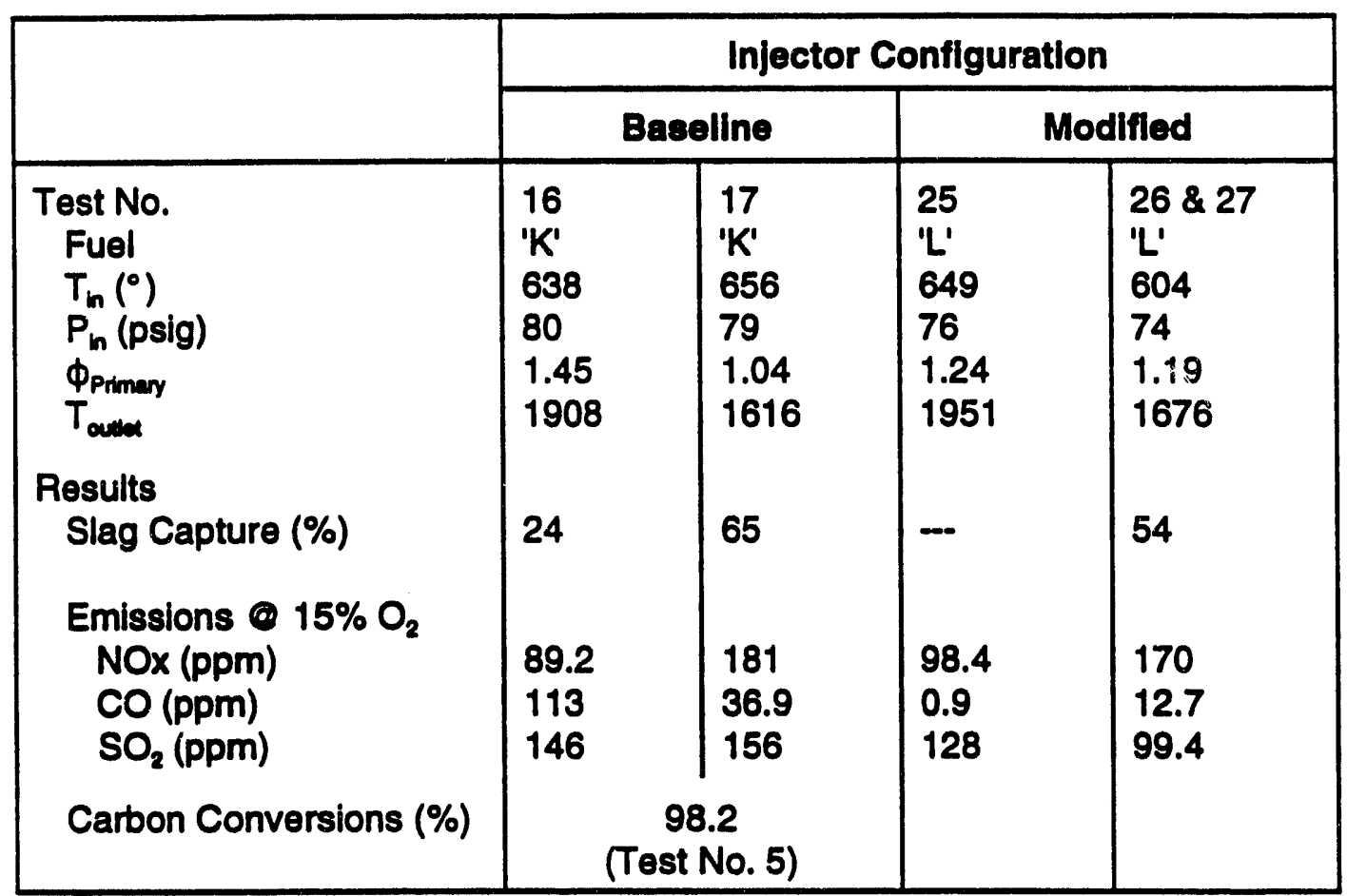

injector TSSC and both the single injector and 4 injector full size combustor. The air assist requirement was not substantially reduced.

A proposal by Purdue University to study the application of effervescent atomization to the coal-fired gas turbine combustor was received and reviewed. The anticipated advantages were reduced air assist flow (air to liquid ratio ALR) and reduced sensitivity of viscosity on atomization. A subcontract was issued to Purdue to develop design data for an injector for the coal-fired Centaur. Design scantlings were provided to Solar and a set of four injectors were manufactured. Due to the curtailment of the program other than atomization tests the only combustor testing was done on the crude oil evaluation described in Section 3.3. A description of the work done by Purdue is contained in Reference 1. 


\subsection{CONCLUSIONS}

This program set out to prove the technical, environmental and economic feasibility of a DCFGT system for industrial cogeneration applications. The program was curtailed before a proof-of-concept engine test could be camied out. The test results from both subscale and full size rigs demonstrated that the system being evaluated was technically feasible although there remained some combustor related problem areas to be solved including refractory material selection and installation and implementation of a slag removal system in the primary combustor zone. In these areas there are encouraging indications that the problems are not insurmountable.

Environmentally; $\mathrm{NO}_{x}$ levels as low as 30 ppmv corrected to $15 \%$ oxygen and CO levels down to 10 ppmv were demonstrated. Control of sulfur dioxide emissions by injecting calcium based sorbents into the secondary zone was shown to be feasible. There were no published limits for these species but the following goals has been established during the program:

$$
\begin{array}{llll}
\mathrm{NO}_{x} & \text { ppmv } 15 \% \mathrm{O}_{2} & <125 \\
\mathrm{CO} & \text { ppmv } 15 \% \mathrm{O}_{2} & <50 \\
\mathrm{SO}_{2} & \text { ppmv } 15 \% \mathrm{O}_{2} & <75
\end{array}
$$

Economically the major consideration was fuel cost, both of the CWM and the competing fuels such as natural gas and distillates. The lowest projection for the price of CWM meeting the specification that was developed during the program was approximately $\$ 3.00$ per million Btu (MMBtu). Diesel fuel at $\$ 1.00$ per gallon is about $\$ 7.00$ per MMBtu. However most industrial cogeneration plants burn natural gas with distillate fuels used only as backup or standby fuel. Studies conducted during the program indicated that the price of a clean fuel like natural gas or light distillate would have to be at least $\$ 5.70$ per MMBtu for a DCFGT system burning $\$ 3.00$ per MMBtu CWM to be competitive.

In summary a direct coal-fired gas turbine cogeneration system is not economically competitive at present natural gas prices. Technical problems exist but there does not appear to be any absolute show stoppers at this time. The demonstrated levels for $\mathrm{NO}_{\mathrm{x}}$ and $\mathrm{CO}$ compare favorably with current levels being stated by gas turbine manufacturers but $\mathrm{NO}_{x}$ as down to $10 \mathrm{ppmv}$ might be difficult for a rich-lean system buming fuels with significant amounts of fuel-bound nitrogen. 


\subsection{RECOMMENDATIONS}

In view of the conclusion that with natural gas prices at their current levels a DCFGT is not economically feasible, the data and information generated by this program should be preserved so that if natural gas prices were to increase to such a level as to make a DCFGT competitive the development does not start at square one.

There are some areas of the combustor that would need immediate attention if development resumed. These include: refractory material selection and installation and implementation of a slag removal system in the primary combustor zone.

While the refractory materials performed satisfactorily in the scale components problems occurred in the full size components. The failures could be due to improper material selection or to installation and curing techniques. The full size combustor is 48 inches in diameter at its largest point. Work in casting and curing these large shapes is needed.

Slag removal systems are not unique to this application so work is being done and could be used if development of a DCFGT resumed. 


\section{REFERENCES}

1. Sojka, P.F., Santangelo, P.J., Geckler, S.C., Buckner H.N., and Stapleton, S.E., "Effervescent Atomization Applied to the Solar Turbines Coal-Fired Centaur Program", Purdue University, Final Report. 


\section{APPENDIX A}

Appendix A contains CWM slurry fuels which have been tested at Solar's combustor rigs (TSSC, IBSTF and HESR) and full-scale combustor. The slurry fuel properties, coal source, particle size, and ash composition and fusion temperature are listed for each tested fuel. The majority of slurries were formulated with the blend of eastern Kentucky coals, except few coals have been used for special testing purposes. A different batch name was referred to each preparation and shipment. 


\begin{tabular}{|c|c|c|c|c|c|c|}
\hline Cod & C & D & $\mathbf{E}$ & $\boldsymbol{F}$ & $\mathbf{a}$ & H \\
\hline Eoures & $\begin{array}{l}80 x \text { Kentucky } 6 \\
20 \% \text { Extiom }\end{array}$ & $\begin{array}{l}80 \% \text { Kentucky } 8 \\
20 \% \text { Entiom }\end{array}$ & Splint & Pownattan & $\begin{array}{l}\text { Pownatten } \\
\text { with } 8.3 \% \text { Lims }\end{array}$ & $\begin{array}{l}75 \% \text { Chan Elinom } \\
25 \% \text { Raced Ellown }\end{array}$ \\
\hline Cond consing (wits) & $\$ 4.10$ & 52.50 & 85.80 & 60.60 & 49.80 & 54.00 \\
\hline Am Costent (wrs) & 2.10 & 120 & 1.70 & 3.40 & 7.50 & 1.26 \\
\hline \multicolumn{7}{|l|}{ Partiolo Content } \\
\hline * Pesaing 100 mitoren & 100.00 & & 90.80 & 10000 & 100.00 & \\
\hline$x$ Paeaing 74 mioren & & 82.10 & 80.70 & 100.00 & 100.00 & \\
\hline X Peesing 46 mieren & & & 80.00 & 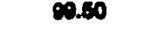 & $\boldsymbol{0 . 6 0}$ & $\infty . \infty 0$ \\
\hline \% Pasaino 37 mboren & & & 71.60 & 0.70 & 9a.70 & $\infty .60$ \\
\hline \% Paceino 28 mieron & & & 63.70 & 2280 & 82.60 & 0200 \\
\hline X Preaing 18 milesen & & & 86.40 & 74.00 & 74.00 & 0000 \\
\hline X Pacingo 8 miterten & & & 24.00 & 38.00 & 3200 & 86.00 \\
\hline 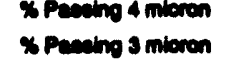 & & & & & & 440 \\
\hline x pecening 2 mideren & & & & & & 3200 \\
\hline & & & & & & $\begin{array}{l}2.100 \\
17.80\end{array}$ \\
\hline Manen 8 bes (mbron) & 14.10 & 21.00 & 21.00 & 11.60 & 11.80 & 9.10 \\
\hline \multicolumn{7}{|l|}{ Sumy Viacoelly (cp) } \\
\hline 100hex & 300.00 & 330.00 & 360.00 & 360.00 & 300.00 & 238.00 \\
\hline $1000 / 200$ & & 276.00 & 100.00 & 700.00 & 250.00 & 428.00 \\
\hline Eimy (Btulo) & $\pi 00$ & 7801 & 7618 & 778 & 6100 & 7245 \\
\hline \multicolumn{7}{|l|}{ Proximate Anabois (wirs) } \\
\hline $\operatorname{Ans}$ & 3.8 & 2.23 & 3.08 & 5.82 & 13.82 & 2.30 \\
\hline Volatives & 30.10 & 34.80 & 37.40 & 37.51 & 38.43 & 31.70 \\
\hline Fund Certon & 60.02 & 62.07 & 50.87 & $8 a .97$ & 47.74 & 2000 \\
\hline \multicolumn{7}{|l|}{ Uninat Anetyals } \\
\hline Carben & $\pi .10$ & 84.18 & 81.20 & 81.44 & 8233 & 868 \\
\hline Oxyen & 14.38 & 2.30 & 2.46 & 6.6 & 0.18 & 7.38 \\
\hline Hydrooen & 5.80 & 5.20 & 4.91 & 5.28 & 5.67 & 5.00 \\
\hline Nitroeen & 1.82 & 1.64 & 1.51 & 1.50 & 1.53 & 1.18 \\
\hline Sulter & 0.90 & 0.58 & 0.60 & 3.13 & 3.28 & 0.50 \\
\hline \multicolumn{7}{|l|}{ Ach Compoedition } \\
\hline so, & 33.00 & 40.30 & $\mathbf{4 6 . 8 0}$ & 42.60 & 13.00 & 53.50 \\
\hline $\mathbf{A p}_{\mathbf{P}}$ & 28.10 & 28.00 & 28.70 & 2200 & 7.60 & 2120 \\
\hline Faph & 11.00 & 16.20 & 18.80 & 20.00 & 7.10 & 10.00 \\
\hline Ceo & 1.30 & 5.02 & 5.16 & 1.91 & 18.20 & 4.00 \\
\hline$M_{\infty}$ & 0.61 & 1.10 & 1.30 & 0.42 & 11.40 & 0.06 \\
\hline Napo & 0.01 & 1.70 & 0.30 & 0.60 & 1.21 & 2.00 \\
\hline Ko & 1.08 & 0.30 & 0.31 & 1.30 & 0.40 & 1.30 \\
\hline non & 2.07 & 1.67 & 1.80 & 1.11 & 0.33 & 1.00 \\
\hline $\mathrm{MnO}$ & 0.07 & 0.07 & 0.02 & 0.08 & 0.04 & \\
\hline$P_{9} O_{1}$ & 0.31 & 0.48 & 0.67 & 0.08 & 0.04 & 0.20 \\
\hline $\mathbf{V}_{\mathbf{8}} \mathbf{O}_{\mathbf{6}}$ & 0.00 & 0.07 & 0.00 & 0.08 & 0.02 & \\
\hline Poo & 0.04 & 0.08 & 0.03 & 0.06 & 0.01 & \\
\hline \multicolumn{7}{|c|}{ An Fuelon Tempenture (P) } \\
\hline \multicolumn{7}{|c|}{ Oxdedinoraducino } \\
\hline Inliat Dafometion & 26702460 & $2358 / 2230$ & $2396 / 2140$ & $3402 / 2468$ & $2512 / 2000$ & 25192020 \\
\hline Solienino & +27002000 & $2303 / 2288$ & 25302278 & $2802 / 2480$ & 25442103 & 28080278 \\
\hline Hemiepheried & +270028650 & $2521 / 2360$ & 24602305 & 28162497 & 25802351 & +27000280 \\
\hline Fluld & $+2700 / 2700$ & $2555 / 2404$ & $2518 / 2486$ & $2518 / 2498$ & $2883 / 2440$ & $+2700 / 2810$ \\
\hline
\end{tabular}




\begin{tabular}{|c|c|c|c|c|c|c|}
\hline Conl & 1 & $\mathbf{J}$ & $\mathbf{K}$ & $\mathbf{L}$ & $M$ & $\mathbf{N}$ \\
\hline Soures & $\begin{array}{l}80 \% \text { Kentuatioy } 8 \\
20 \% \text { Extion }\end{array}$ & $\begin{array}{l}\text { cox Kentuchy iA } \\
20 \% \text { Entiom }\end{array}$ & $\begin{array}{l}\text { cox Kantuchy } 4 A \\
20 \% \text { Elliom }\end{array}$ & $\begin{array}{l}\text { cox Kentucisy \&A } \\
20 \% \text { Eutrom }\end{array}$ & Clam Elinom & $\begin{array}{l}\text { c0\% Kentuchy } 4 A \\
20 \% \text { Euthom }\end{array}$ \\
\hline Conl extent (wry) & 84.10 & 84.00 & 84.10 & 84.80 & 85.00 & 84.88 \\
\hline Ans Content (wtx) & 2.18 & 2.11 & 2.15 & 2.18 & 1.78 & 2.21 \\
\hline \multicolumn{7}{|l|}{ Partioio Content } \\
\hline × Pasaing 100 mieren & $\infty . \infty 0$ & & 100.00 & & & \\
\hline X Paceing 74 mioron & 0.00 & & 100.00 & 100.00 & & \\
\hline X Paning 46 mioren & 97.80 & 90.40 & 80.40 & $\bullet .80$ & 100.00 & $\boldsymbol{\bullet . \infty}$ \\
\hline X Pereatno 37 mieren & 80.70 & 80.10 & $\bullet .30$ & $\bullet .10$ & 100.00 & caso \\
\hline \% Pancing 26 mberen & $\cos 40$ & 80.80 & 80.80 & 8900 & $\mathbf{0 0 . 5 0}$ & $\infty . \infty 0$ \\
\hline X Pacuing 18 mieron & 3220 & 73.30 & 80.60 & 640 & 91.00 & 78.60 \\
\hline \% Pacaing 8 mineren & 2000 & 37.30 & 34.30 & 37.10 & 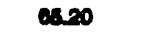 & 42.10 \\
\hline Xs Paceing 4 mioren & & 30.00 & & & 84.40 & 31.20 \\
\hline x Paceing 3 mieren & & 21.00 & & & 40.00 & 2200 \\
\hline$x$ Peceino 2 miberen & & 18.60 & & & 31.00 & 18.10 \\
\hline x Paseing 1 miaron & & 8.80 & & & 21.50 & 4.10 \\
\hline Man 8bs (mioron) & 14.00 & 14.00 & 9.80 & 12.80 & 7.80 & 9.70 \\
\hline \multicolumn{7}{|l|}{ Elumy Virocealy (cp) } \\
\hline 1001anes & 480.00 & 470.00 & 300.00 & 378.00 & 300.00 & 200.00 \\
\hline - $1000 \mathrm{hres}$ & 300.00 & 588.00 & & & 370.00 & 488.00 \\
\hline 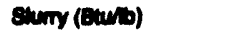 & $\operatorname{man}$ & 7004 & 7043 & 0976 & 7180 & 1004 \\
\hline \multicolumn{7}{|l|}{ Procinecto Analyed (wry) } \\
\hline $\operatorname{Am}$ & $3 e$ & 200 & 3.97 & 4.00 & 200 & 4.08 \\
\hline Volatimes & 346 & 34.82 & 3480 & 37.00 & 32.67 & 35.67 \\
\hline Fued Certen & $\operatorname{cose}$ & 89.60 & 01.20 & 82.40 & 6.06 & $\infty .00$ \\
\hline \multicolumn{7}{|l|}{ Uuinats Anapyis } \\
\hline Cowreen & 84.05 & 83.84 & 83.97 & 83.71 & 85.20 & 82.24 \\
\hline Ominn & 7.04 & 8.86 & 7.61 & 2.00 & 7.07 & 2.11 \\
\hline Androgen & 8.81 & 8.43 & 5.04 & 8.62 & 8.28 & 8.60 \\
\hline Nureogen & 1.50 & 1.02 & 1.22 & 1.80 & 1.03 & 2.10 \\
\hline sumer & 0.82 & 0.85 & 0.86 & 0.72 & 0.73 & 0.80 \\
\hline \multicolumn{7}{|l|}{ An Compocition } \\
\hline 80, & 4.60 & 52.00 & 42.60 & 47.60 & 49.60 & 44.60 \\
\hline $\mathbf{A l O}$ & 2020 & 28.00 & 29.50 & 27.00 & 26.10 & 22.00 \\
\hline Fap & 16.00 & 6.86 & 17.60 & 16.01 & 11.60 & 1800 \\
\hline coo & 1.74 & 2.30 & 1.67 & 283 & 2.40 & 200 \\
\hline$m$ & 0.68 & 0.57 & 0.50 & 0.85 & 0.00 & 0.01 \\
\hline Napo & 1.38 & 1.87 & 2.37 & 1.58 & 1.00 & 1.50 \\
\hline Ko & 1.10 & 1.23 & 2.86 & 0.00 & $1 . \infty 0$ & 080 \\
\hline no, & 1.46 & 1.20 & 1.13 & 1.16 & 0.00 & 1.30 \\
\hline $\min \theta_{1}$ & 0.08 & & 0.04 & & & \\
\hline$P_{\mathbf{P}} \mathbf{O}_{\mathbf{B}}$ & 0.51 & 0.19 & $\phi .08$ & 0.20 & 0.20 & 0.30 \\
\hline $\mathbf{V}_{\mathbf{N}}$ & 0.04 & & 0.08 & & & \\
\hline Poo & $\infty .12$ & & $\infty .12$ & & & \\
\hline \multicolumn{7}{|c|}{ An Fuiden Tempendure (PF) } \\
\hline Inilat Dolemention & 20283418 & 24862375 & 24002160 & 29480480 & 28000006 & 24002144 \\
\hline Schoning & 20602475 & +270027004 & 2aporaico & +27000400 & 20copeas & cestrases \\
\hline Meningherited & 20000218 & +270027004 & $2030 \mathrm{rac0}$ & $+2700 p a s 0$ & 2070 rases & 20092410 \\
\hline Fuld & 2700 reos & $42700 / 27004$ & 26802580 & +2700 reses & $2087 r 202$ & 207e/2491 \\
\hline
\end{tabular}




\begin{tabular}{|c|c|c|c|c|c|}
\hline Coal & 0 & $\mathbf{P}$ & $\mathbf{a}$ & $\mathbf{A}$ & $T$ \\
\hline Source & $\begin{array}{l}\text { 50\% Kentucky 4A } \\
\text { 50\% Rlver Queen }\end{array}$ & $\begin{array}{l}51 \% \text { Kentucky 4A } \\
49 \% \text { Rlver Queen }\end{array}$ & Kentucidy $4 A$ & Kentucky of & $\begin{array}{l}\text { Kentucisy aA } \\
\text { Elkhom }\end{array}$ \\
\hline Coal content (w1\%) & 54.18 & 53.46 & 51.0 & 54.34 & 54,38 \\
\hline Ach Content (wt\%) & 2.15 & 2.19 & 1.97 & 2.07 & 1.85 \\
\hline \multicolumn{6}{|l|}{ Particlo Content } \\
\hline \% Peasing 74 micron & & 99.95 & $\begin{array}{l}99.83 \\
99.81\end{array}$ & 99.77 & $\mathbf{8 9 . 7 0}$ \\
\hline \% Paseing 45 mioron & 99.60 & 99.43 & 88.70 & 89.08 & 88.83 \\
\hline \% Passing 37 micron & 99.50 & 99.03 & 98.29 & 98.51 & 88.16 \\
\hline * Paseing 25 micron & 98.00 & 91.90 & 93.45 & 97.91 & 84.88 \\
\hline \% Paseing 15 micron & 86.50 & 80.15 & 68.48 & 75.18 & 75.08 \\
\hline X Pasaino 5 micron & 50.40 & 59.70 & 3820 & 41.08 & 41.04 \\
\hline X Paseing 4 micron & $\mathbf{3 9 . 4 0}$ & 41.89 & 28.12 & 29.42 & 29.35 \\
\hline * Paseing 3 mioron & 29.00 & 34.45 & 18.34 & 22.98 & 22.30 \\
\hline \% Paseing 2 miaron & 18.00 & 23.98 & 12.64 & 16.37 & 14.65 \\
\hline \% Passing 1 micron & 3.50 & 10.52 & $\mathbf{3 . 5 8}$ & 5.39 & 4.48 \\
\hline Mean Size (micron) & 8.00 & 7.60 & 12.60 & 10.40 & 10.87 \\
\hline \multicolumn{6}{|l|}{ Slumy Viscosity (cp) } \\
\hline - 100/sec & 300.00 & 300 & 310 & 150 & 275 \\
\hline 1000/800 & 400.00 & 340 & 178 & 190 & 300 \\
\hline Slumy (Btu/b) & 7013 & 6868 & 6641 & 7174 & 7268 \\
\hline \multicolumn{6}{|l|}{ Proxdmate Analysis (wt\%) } \\
\hline Ach & 3.93 & 4.05 & 3.84 & 3.80 & 3.01 \\
\hline Volatlles & 38.01 & 38.78 & 37.32 & 34.82 & 34.58 \\
\hline Flxed Carbon & 58.08 & 57.17 & 58.84 & 6128 & 62.41 \\
\hline \multicolumn{6}{|l|}{ Uttimato Anahysis } \\
\hline Carbon & 8223 & 81.30 & 82.52 & 84.09 & 84.40 \\
\hline Oxygen & 8.85 & 9.53 & 11.51 & 7.68 & 7.78 \\
\hline Hydrogen & 5.68 & 5.51 & 3.68 & 5.58 & 5.53 \\
\hline Nitrogen & 1.80 & 1.82 & 1.85 & 1.78 & 1.68 \\
\hline Sultur & 1.44 & 1.84 & 0.43 & 0.92 & 0.61 \\
\hline \multicolumn{6}{|l|}{ Ash Composittion } \\
\hline $\mathrm{SIO}_{2}$ & 50.60 & 48.02 & 52.04 & 46.49 & 42.58 \\
\hline $\mathrm{A}_{2} \mathrm{O}_{3}$ & 23.10 & 28.36 & 31.73 & 28.31 & 28.59 \\
\hline $\mathrm{Fe}_{2} \mathrm{O}$ & 13.80 & 16.75 & 82 & 12.00 & 13.80 \\
\hline $\mathrm{CaO}$ & 2.70 & 1.56 & 2.9 & 4.16 & 5.17 \\
\hline $\mathrm{MgO}$ & 0.01 & 0.56 & 0.39 & 0.79 & 0.59 \\
\hline $\mathrm{Na}_{2} \mathrm{O}$ & 120 & 0.88 & 121 & 1.20 & 1.44 \\
\hline$K_{2} O$ & 1.30 & 1.83 & 1.01 & 0.98 & 0.85 \\
\hline $\mathrm{TO}_{2}$ & 1.30 & 1.14 & 1.16 & 1.09 & 1.03 \\
\hline $\begin{array}{l}\mathrm{P}_{2} \mathrm{O}_{6} \\
\mathrm{~V}_{2} \mathrm{O}_{6} \\
\mathrm{PbO}\end{array}$ & 0.20 & 0.23 & 0.98 & 0.16 & 0.14 \\
\hline \multicolumn{6}{|c|}{$\begin{array}{l}\text { Ash Fusion Temperature ( }{ }^{\circ} F \text { ) } \\
\text { Oxidizing/Reducing }\end{array}$} \\
\hline Initial Deformation & 2637/2070 & $2548 / 2399$ & $+2700 / 2602$ & $2672 / 2387$ & $2422 / 2287$ \\
\hline Softening & $2700 / 2190$ & $2656 / 2447$ & +27002685 & $2694 / 2418$ & 26402355 \\
\hline Hemispherical & $2700 / 2270$ & $2665 / 2463$ & $+2700 / 27004$ & $+2700 / 2467$ & 26842425 \\
\hline Fluld & $2700 / 2474$ & $2673 / 2486$ & $+2700 / 2700 t$ & $+2700 / 2651$ & $2680 / 2467$ \\
\hline
\end{tabular}




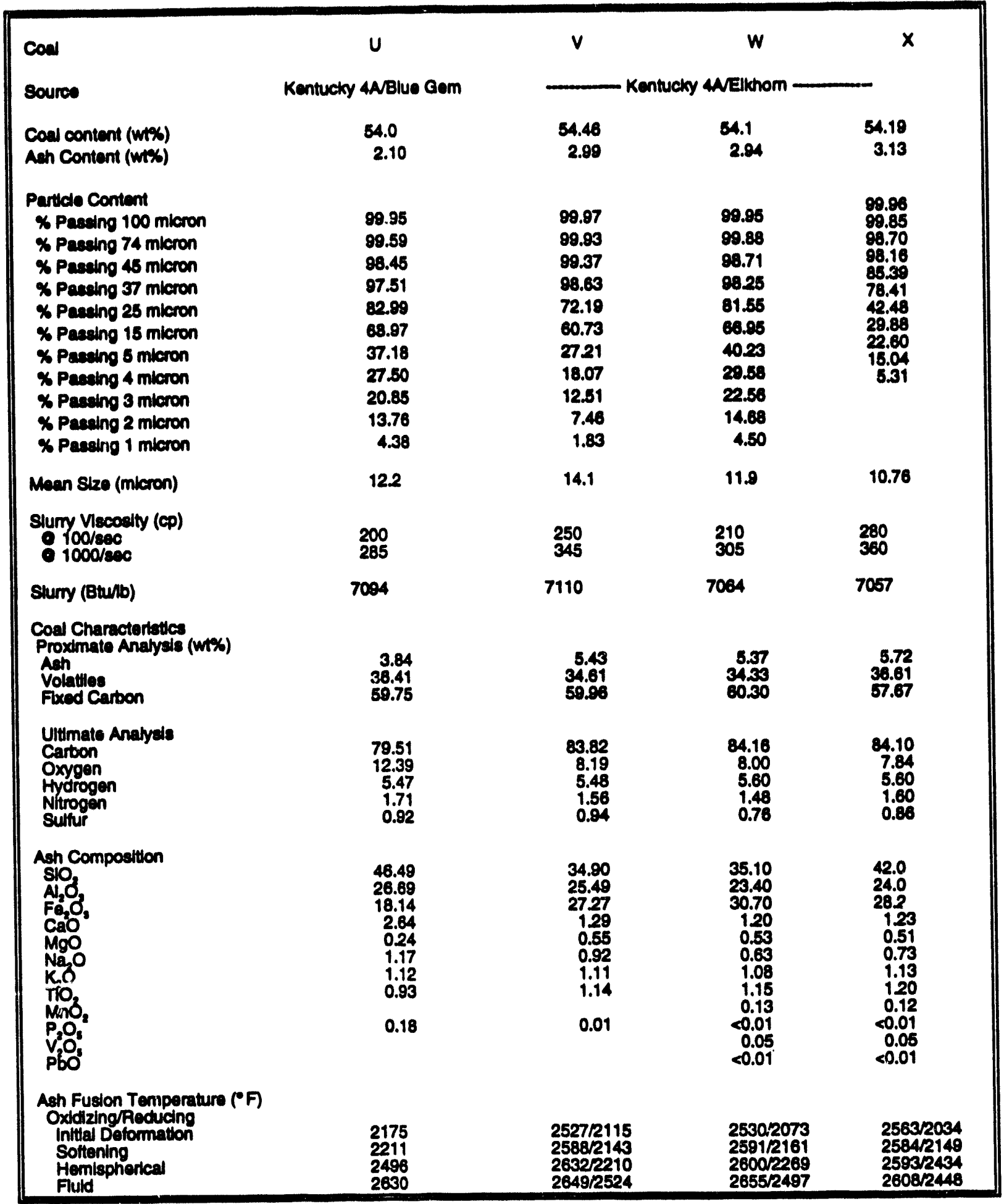



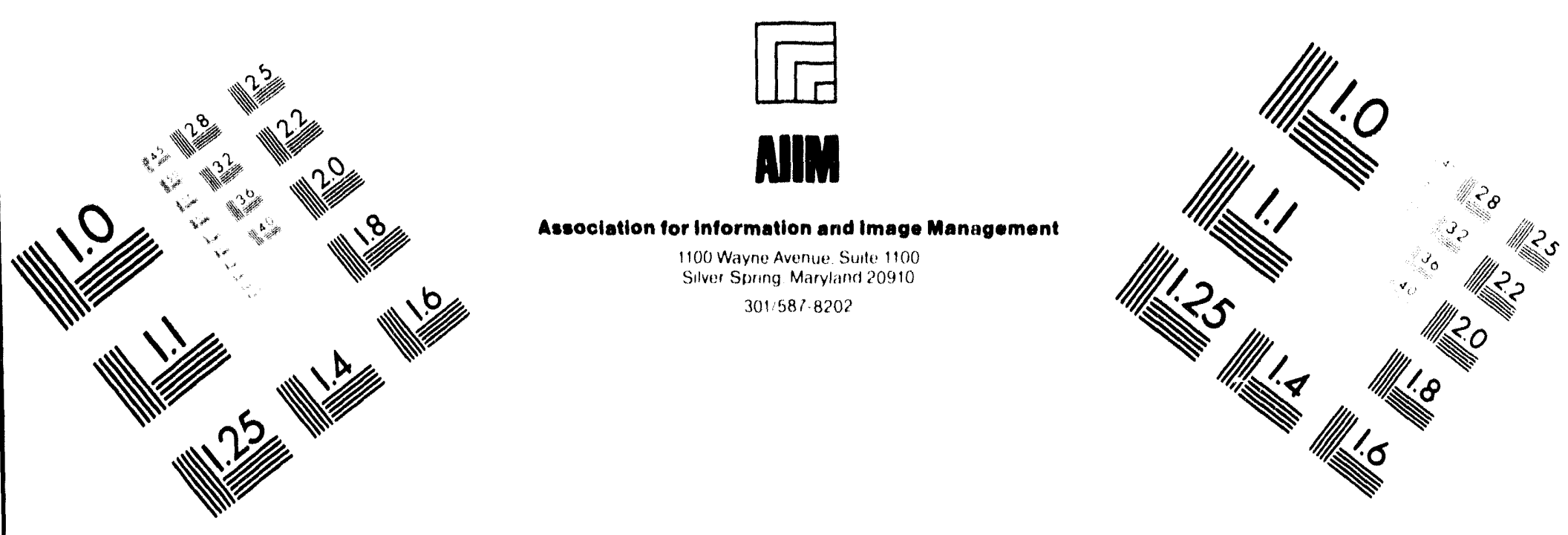

\section{Centimeter}

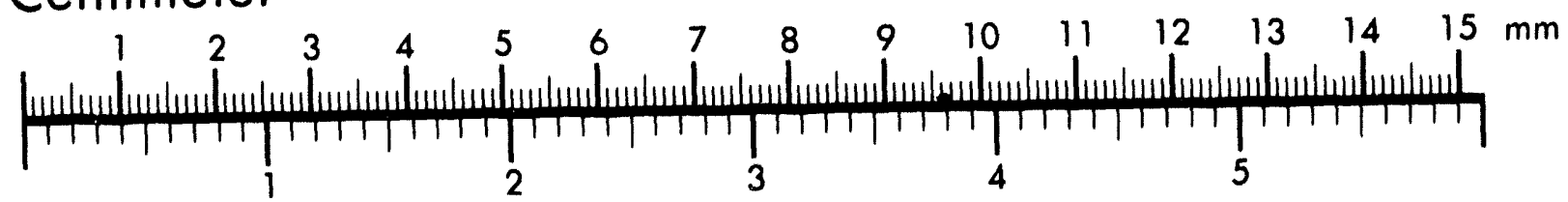
Inches
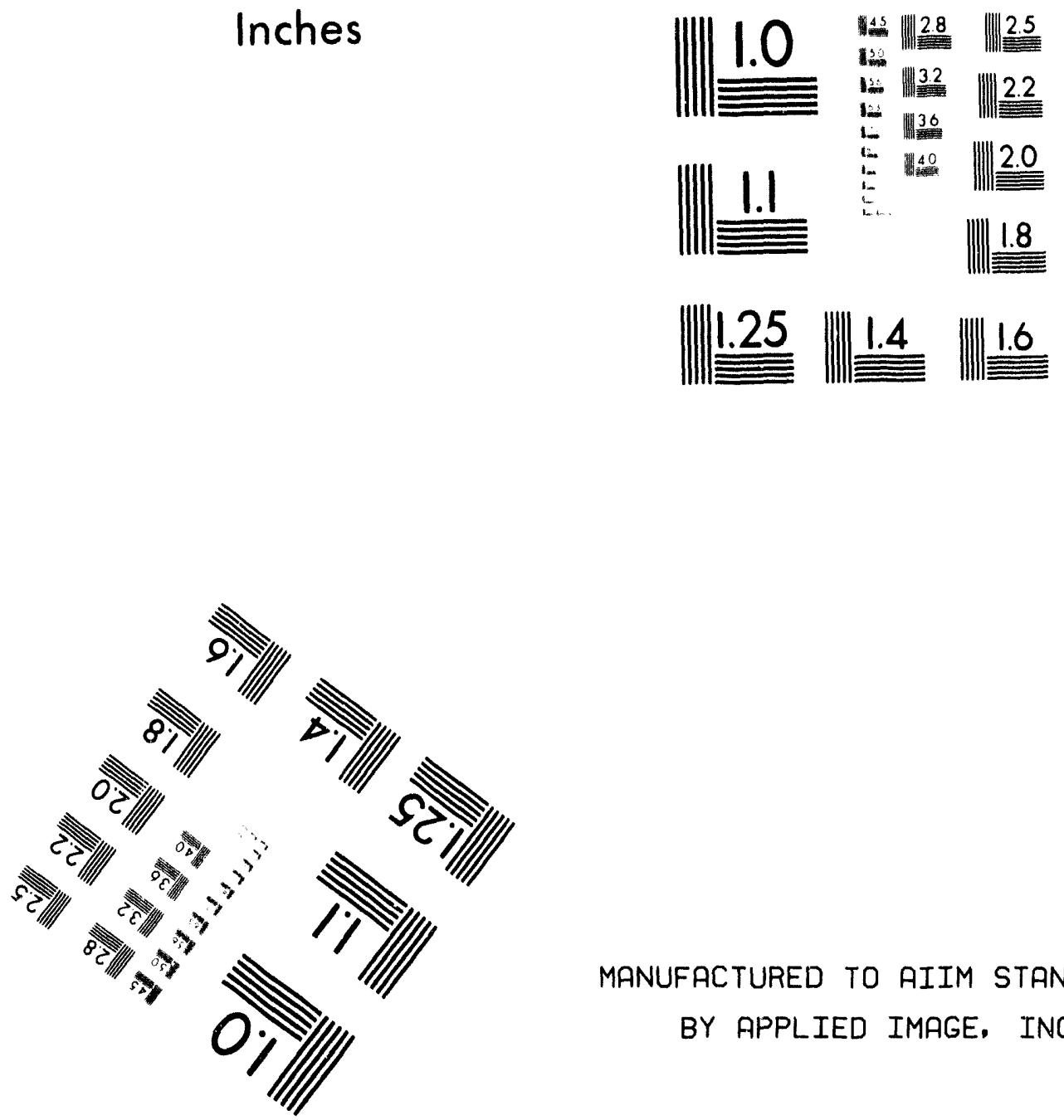

MANUFACTURED TO AIIM STANDARDS

BY APPLIED IMAGE, INC.

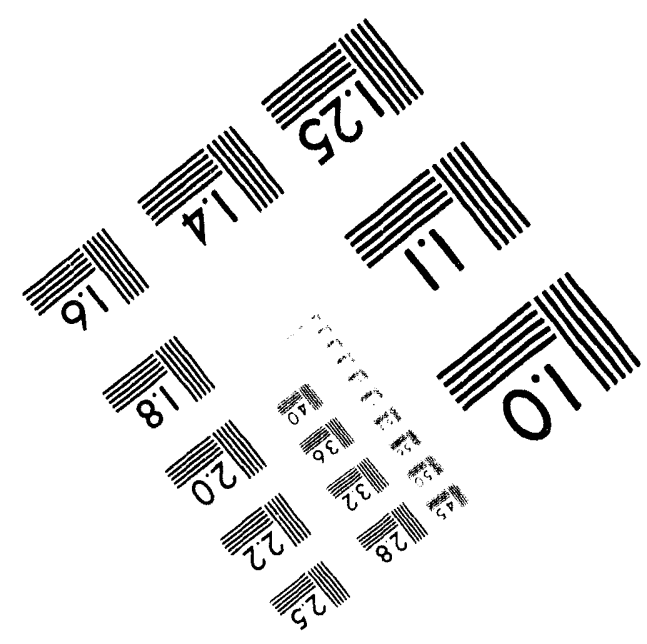



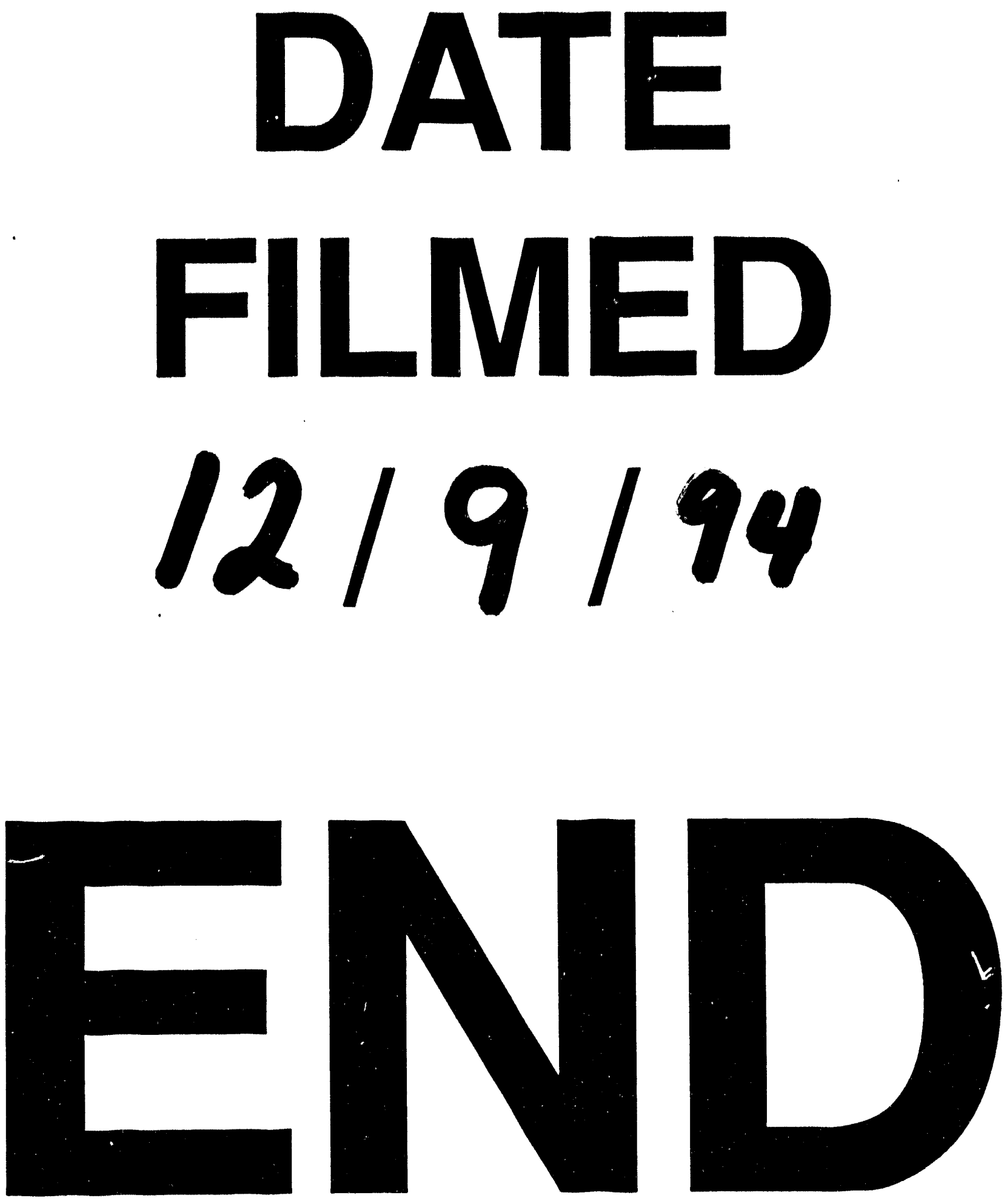